\title{
فقه القيادة العسكرية
}

هن خلال قصة طالوت (دراسة تأصيلية)

\section{د/ عادل الصاوي عبد الغفار أبو زيد}

قسم الاعوة والثقافة الإسلامية، كلية أصول الدين والدعوة

جامعة الأزهر، شبين الكوم, جمهورية مصر العربية

adelabuzaid.adv@azhar.edu.eg البريا الجامعي: 


\section{קט:ص:}

بدأ الباحث بملخص أظهر من خلالهه مقومات الثخصية القيادية, ومن خلال طرحه بيَّن أن

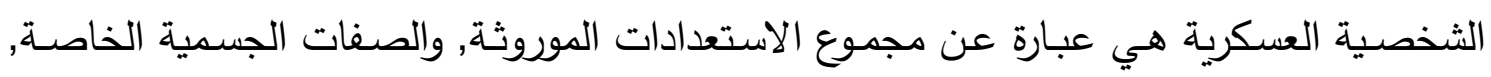

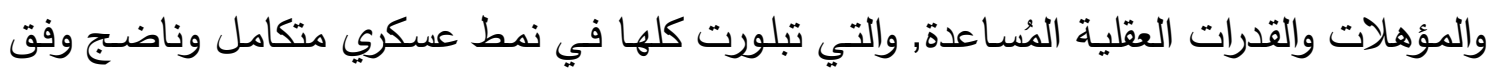

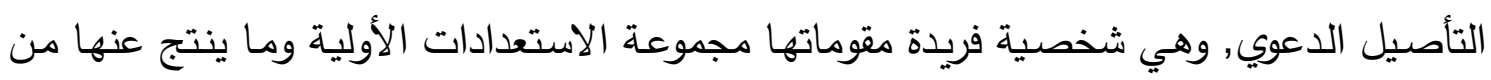
صفات نفسية, وصفات جسمية, وقدرات عقلية, ومؤهلات ريادية, ناهيك عن قوة الثخصية وتأثيرها

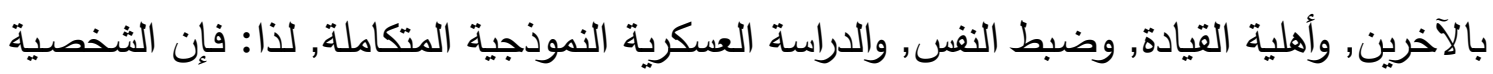

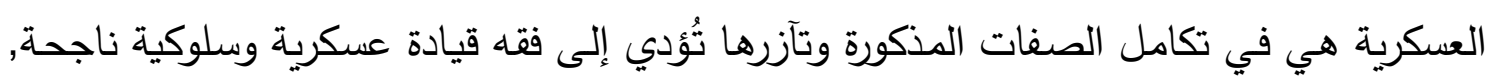

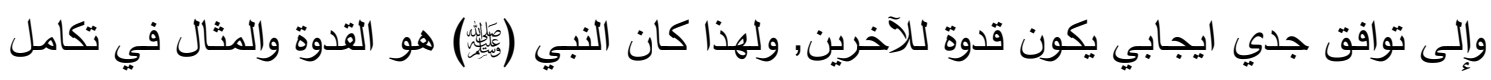

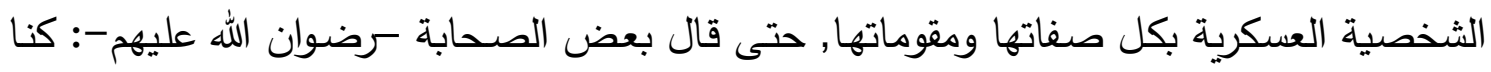

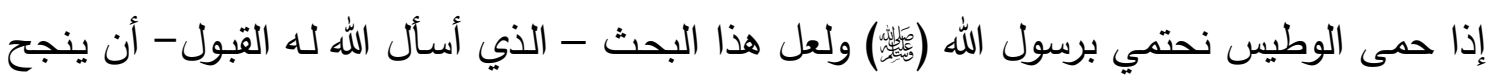

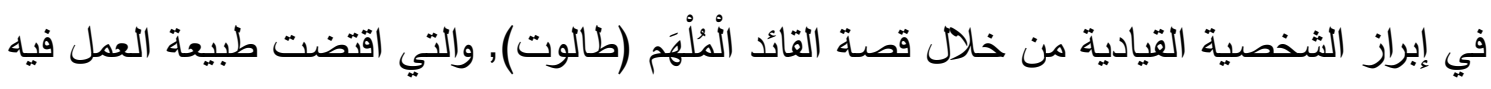

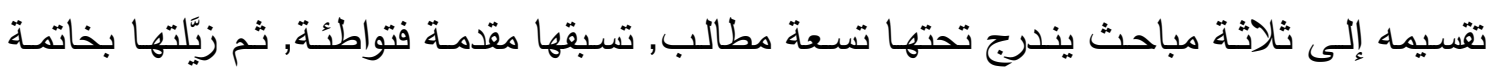

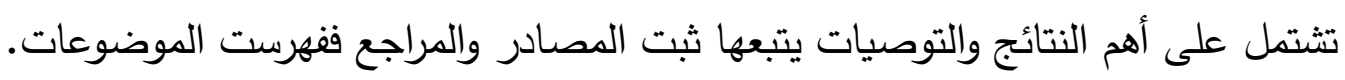
الكلمات المفتاحية: فقه, القيادة، قصة، دراسة، تأصيلية. 
كهُفقه القيادة العسكرية من خلال قصة طالوت

The jurisprudence of military leadership through the story of Taloot (an original study)

\author{
Adel Al-Sawy Abdul Ghaffar Abu Zaid \\ Department of Islamic Call, Faculty of Fundamentals of Religion and \\ Da'wah, Al-Azhar University, Shebin El-Kom, Arab Republic of \\ Egypt \\ E-mail: adelabuzaid.adv@azhar.edu.eg
}

\title{
Abstract;
}

The researcher began with a summary in which he showed the components of the leadership personality, and through his presentation he showed that the military personality is the sum of the inherited preparations, special physical characteristics, and auxiliary mental qualifications and capabilities, all of which crystallized in an integrated and mature military pattern according to the prosecution rationale, and it is a unique personality whose constituents are a group Initial preparations and the resulting psychological qualities, physical qualities, mental abilities, and pioneering qualifications, not to mention the strength of personality and its influence on others, the capacity for leadership, self-control, and the model integrated military study, so: the military personality is in the integration and synergy of the mentioned qualities that lead to jurisprudence Successful military and behavioral leadership, and to a serious, positive consensus that sets an example for others, That is why the Prophet was $\mathrm{He}$ is the example and example in the integration of the military character with all its qualities and components, until some of the Companions - may God be pleased with them - said: If the heat of 
كهيقه القيادة العسكرية من خلال قصة طالوت

turmoil we would have protected the Messenger of God Perhaps this research - which I ask God for him to accept - will succeed in highlighting the leadership personality through the story of the inspired leader (Taloot), the nature of the work in which necessitated dividing it into three topics under which there are nine demands, preceded by an introduction, and then I replaced it with a conclusion that includes the most important results The recommendations are followed by proven sources and references, so the topics are indexed.

Keywords: jurisprudence - leadership - story - study - foundational. 


\section{حولية كلية الدعهوة الإسلامية بالقاهرة}

كهِفقه القيادة العسكرية من خلال قصة طالوت

\section{المقدهة}

الحمد لله الأي هدانا لهذا وما كنا لنهتدي لولا أن هدانا الله، والصلاة وإلسلام على سيدنا ومولانـا

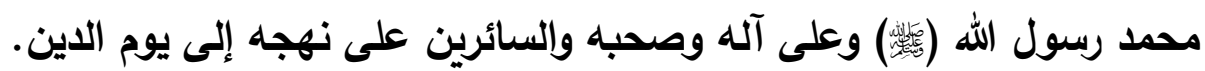

66610

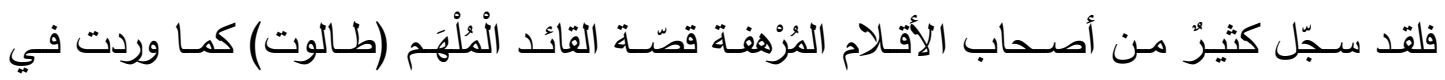

الروايـات، وقد أردت أن أدلـي بـلوي معهم في هذا الموضـوع محساولا استدراك مـا قد يكون فـات بعضهم, محاولاً جمع شتات الموضوع, وعاملاً على إسقاطه على الواقع المعاصر بغية الاستفادة منه للوصسول إلى المستفاد من فقه القيادة في ضوء القصـة المثيرة، وإبراز الذخائر المكنونـة التي تسهم في تحريك الماء الراكد، وتُؤدي دورًا بارزًا في دنيا الناس, فتُصحح المسار لتستلهم الأمسة من غفوتها وتتهض بركب الحضارة والتقدم, لكن حسبهم أنهم قدّموا ما لديهم بأمانـة علميّة ليأتي جيل يلحظ ويستفيد، ويُلقي الأضـواء عليها ليستخرج الدرّ المنثور من بين كلماتها، ومـا زالت المكتبة الإسلاميّة بحاجة إلى مزيد من الدراسات المنهجية لفقه القيادة في عصورها المختلفة, كزمن سليمان

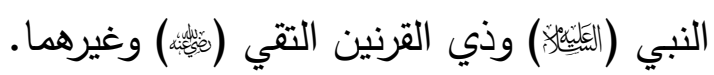
ومن ثمَّ نلحظ الاهتمام القرآني بذكر خبر القائد المُلْهَم (طالوت) حيث إن سياق القصسة جاء في قرابة ثلاثمائـة وبضعة عشر كلمة قرآنية(')، وهذا إن دلّ فإنما يدلّ دلالة واضحة أن الله يريد منا

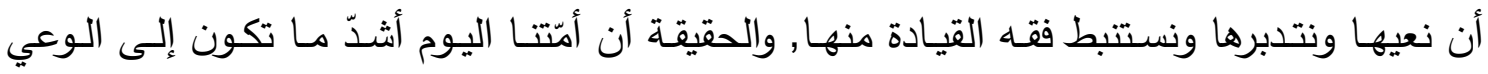
القيادي، وما السياسة الشرعية إلا فقه قيادة وتربية، وإن من أفضل ما تستنبط بـه السياسـة الشرعية

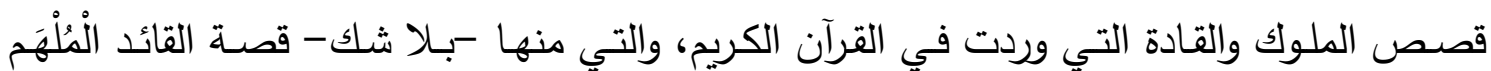

والحقيقة: لم تحظ أيّ أمة من الأمم السابقة في القرآن الكريم (المصدر الأول) بالتتبّع المطوّل

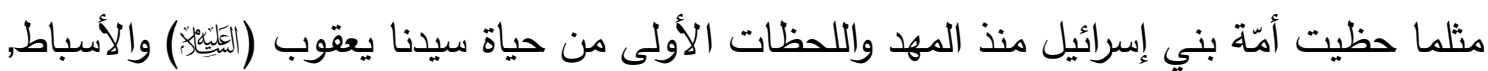
ثم الاستعباد أيام الفراعنة, والخروج الكبير على يد سيدنا موسى (الِّلِّهِ) ثم مرحلة التيه, ثم بداية

(') إنه من سمات الإعجاز : ذلك التوافق بين عدد كلمات القصة في الآيات الكريمة وبين عدد جيش القائد المُلْهَمِ

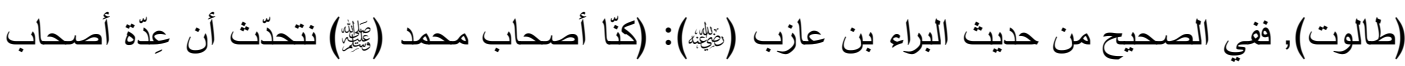
بدر على عِدّة أصحاب طالوت الذين==جاوزوامعه النهر ، ولم يجاوز معه إلا مؤمن، بضعة عشر وثلاثمائة)

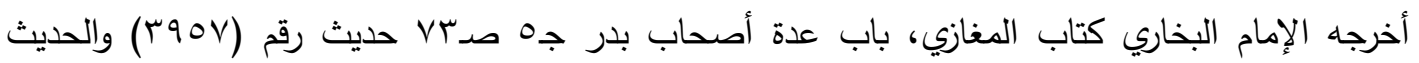

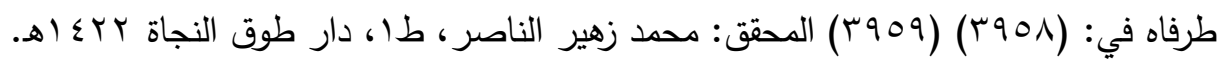




\section{حولية كلية الدعهوة الإسلاهية بالقاهرة}

كهيقفه القيادة العسكرية من خلال قصة طالوت

الطريق إلى بيت المقدس على يد يوشع (اليَلِيّة) وعصر الذلّة والانحطاط في عهد القضاة, ثم مرحلة

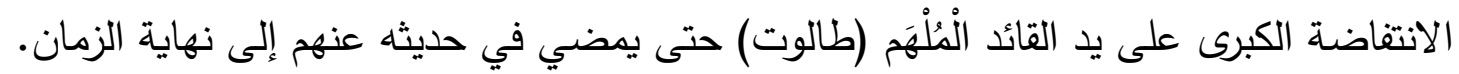
والحق الذي لا ريب فيه أن قصص القرآن الكريم كلها عبر ودروس وعظات، وقد تكون الحاجة ماسة في بعض الأوقات إلى دراسة بعض القصص القرآني أكثر من غيرها، ومن واجب الوقت

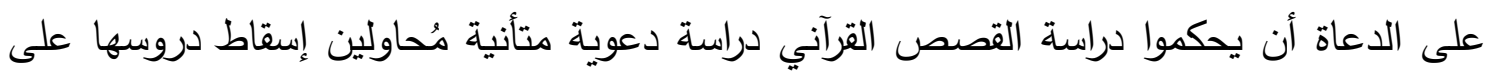
واقهم الماثل وعصرهم الحاضر ، ومن هنا فقط رأيت الحاجة ماسة إلى دراسة قصة القائد المُلْهَم (طالوت) ذلك القائد الذي أنقذ الله به بني إسرائيل -في فترة من الفترات- من السقوط في هوة الضياع والاضمحلال.

والثيء بالثيء يذكر لأن طبائع البشر متقاربة في كل زمان ومكان ما لم تكن متطابقة، فإذا ما

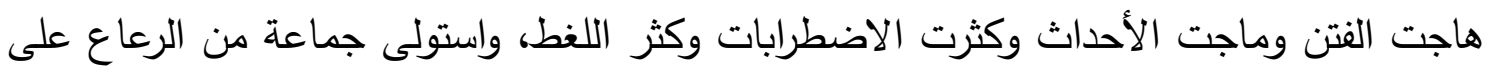
مقاليد الحُكم أو كادوا، وتحدث الرويضضة في أمر العامة وكادت الفتن أن تُودي بالأمة أو المجتمع والوطن، فليس ثمة مخرج من تلك الفتن سوى قائد بصير مُّلْهَم وحاكم خبير مخضرم، أكرمه الله تعالى بمواصفات خاصة ومواهب متعددة وكفاءات متنوعة ليُعيد الأمور إلى نصابها ويرجع بالأمة إلى سالف أمرها حيث كرامتها وعزتها وهيبتها وحرمتها.

ولا أظن أنني قد شردت بعيدا إذا قلت إن مصرنا العزيزة ووطننا الحبيب كاد أن يتعرض لفتن لا

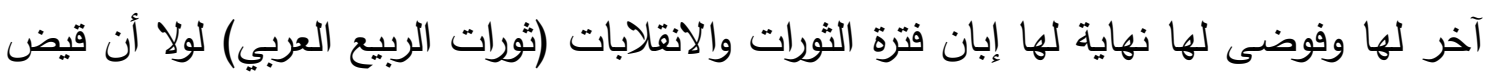
الله تعالى لها من رجالاتها البواسل مَنْ توفرت فيه هذه الشروط وتحققت فيه تلك المواصفات ممن يحملون أرواحهم على أكفهم فداءً لوطنهم وتضحية لشعبهم وبلدهم فكان ما كان من إقرار الأمن تُون والأمان على يد فخامة السيد الرئيس عبدالفتاح السيسي ورفقائه الأمناء، فكان ما كان مما نحمد الله تعالى عليه، ولولا ذلك لكانت بلدنا في مهب الريح كغيرنا من الدول التي تعرضت لِكَم هائل من الفتن والفوضى، نسأل لنا ولسائر البلاد الأمن والأمان.

ولقد فطن إلي ذلك كثير من المفكرين فأشادوا بما قام به الرئيس بل عدوه من الأولياء، جاء الله

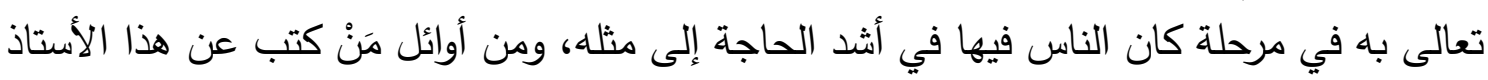

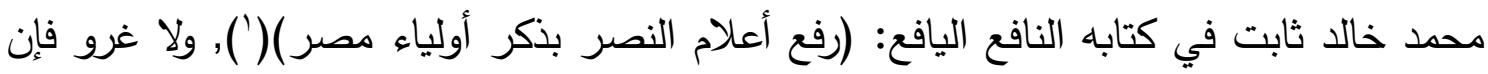

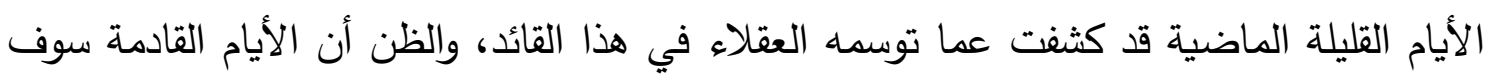
تأتي بالمزيد من إقرار الأمن والأمان والنهضة العلمية والعملية والاقتصادية المنشودة بفضل الله تعالى.

(') يُنظر كتاب: رفع أعلام النصر بذكر أولياء مصر للأستاذ: محمد خالد ثابت جr صرمبه-

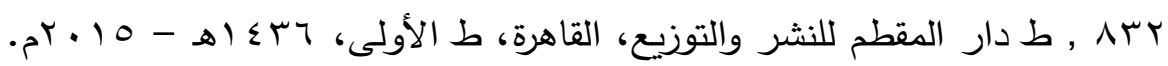




\section{هنهج الدراسة:}

لقد اعتمدت في هذا البحث على عدة مناهج، دعت الحاجة إليها منها('):

\section{أولا: المذهج الاستزدادي:}

الذي يقوم على توثيق المعلومات البحثية واستردادها من مصادرها الأصيلة بأمانة علمية, وهو

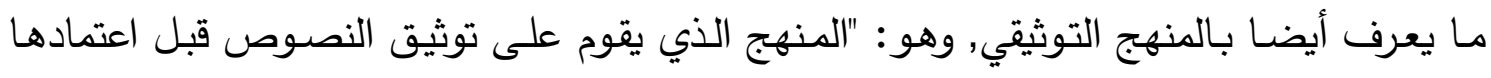

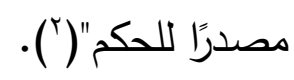

\section{ثانيا: المنهج الاستدلالي:}

حيث أقمت الدليل على جميع القضايا التي تخص القضية موضح البحث، وقىت بتدعيم البحث

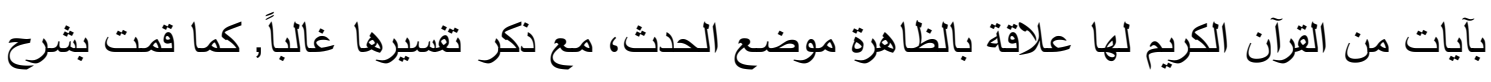

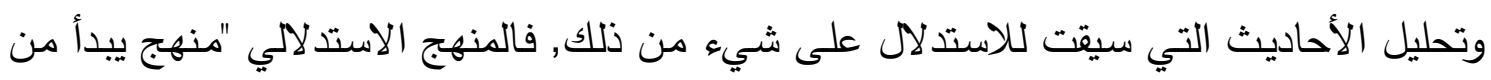

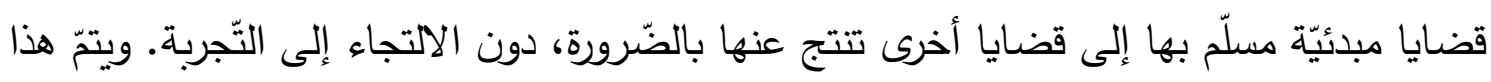
بواسطة القول، أو بواسطة الحساب"(")

\section{ثالثا: المنهج التصليلي:}

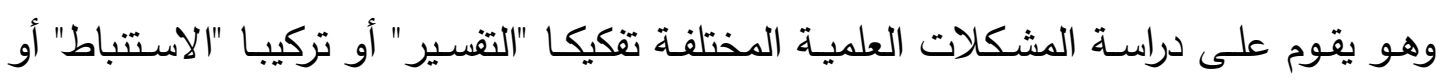

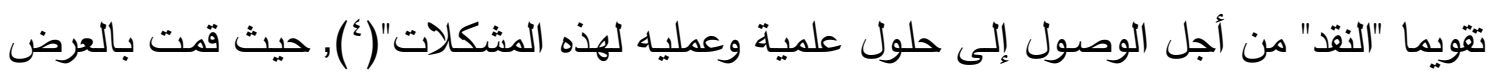

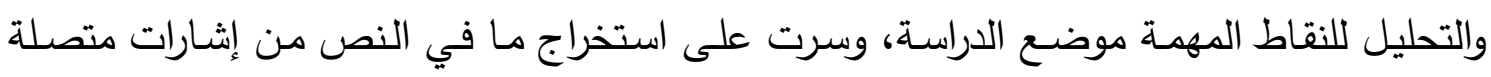

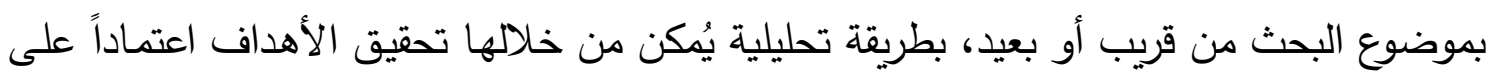
عمل منضبط ومرتب للأجزاء التي يتألف منها النظام كله, بهدف الوصول بطيفة إلى النتائج والتوصيات.

(') ثُظر هذه المناهج كاملة في: مهارات البحث العلمي في الدراسات التربوية والاجتماعية د. حافظ

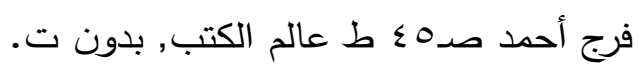

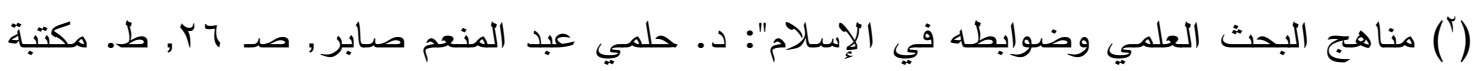

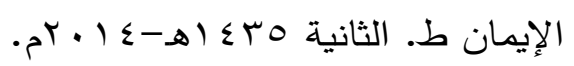

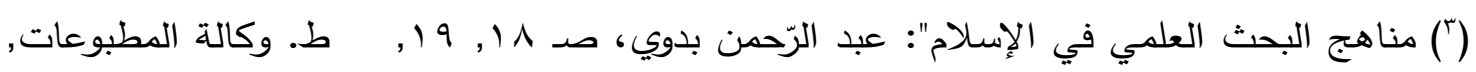

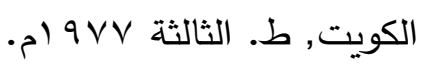
(4) أبجديات البحث في العلوم الثرعية د. فريد الأنصاري صده 9 منشورات الفرقان, الدار البيضاء, ط 


\section{رابعاً: المذهج الاستنباطي:}

وهو المنهج الذي يتيح التوصل إلى القوانين التي تتوقف على طبيعة القضية, يث ينتقل الباحث مـن المقدمات إلى النتائج('). ويقصــ بـه: ااستخراج المعـاني مـن النصـوص بفرط الذهن وقوة

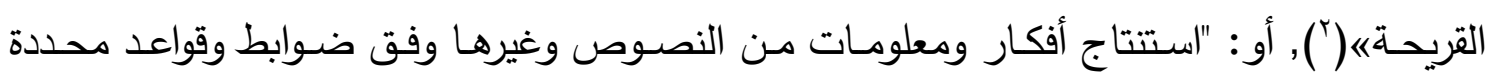
ومتعارف عليها"("), أو: "تتبع الجزئيات كلها أو بعضها للوصول إلى حكم عام يشملها جميعا"()).

\section{ولقد راعيت في بمثي الأهمور التالية:}

أولاً: عزوت الآيات القرآنية إلى السور التي وردت فيها، مـع ذكر اسم السورة ورقم الآية، وذكر أقوال بعض أئهـة التفسير غالباً والتي تخدم موضـوع البحث، كما قمت بتخريج جميع الأحاديث النبويـة الواردة بين ثنايا البحث تخريجا علميا, وأمسا ما ورد في العهد القديم فقد عزوته إلى أصله المترجم باللغة العربية ذاكرا السفر والإصحاح ورقم المقطع. ثانياً: حرصت على جمع المعلومات من مصادرها ومراجعها الأصيلة مباشرة، ورجعت إلى أكثر من مصدر في المسألة الواحدة ما استطعت إلى ذلك سبيلاً، مع الاستفادة من المراجع الحديثة. ثالثا: اعتمدت في هذه الدراسـة على مراجع ذات صـلة وثيقة بالقضـية موضـع الحدث لزيـادة التوضيح والبيان.

رابعاً: استعنت بما جاء عن أهل الكتاب في العهد القديم واقفاً منها موقف الناقد مستخدماً في نقدها العلوم النقلية والعقلية، وكلام العلماء القدماء والمحدَثين في ذلك.

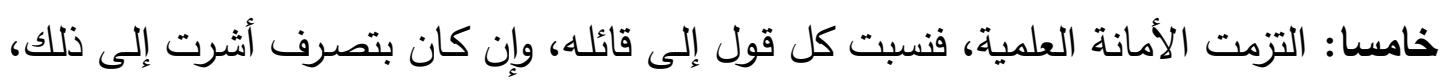
مع كتابة اسم الكتاب ثم المؤلّف ثم المحقق إن وجد ورقم الجزه إن وجد والصفحة وتاريخ ومكان الطبع إن وجد، وهذا عند ذكر المرجع لأول مرة، واستغنيت باسم الكتاب والمؤلف ورقم الصفحة بعد ذلك حينما يتكرر الرجوع إلى نفس المرجع مع الإشارة إلى أنه مرجع سابق ب(م. س).

(') مناهج البحث العلمي د. عبد اللطيف محمد العبد صده ط مكتبة النهضة المصرية بالقاهرة طا . ) $9 \vee 9-\$ 1 r 9 \wedge$

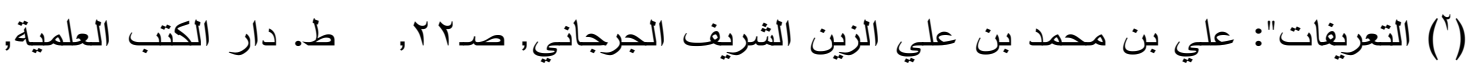

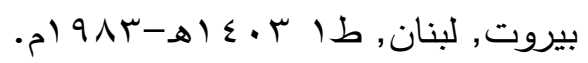

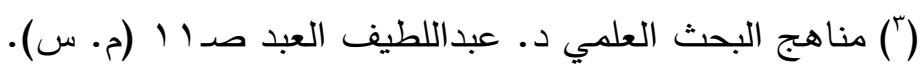

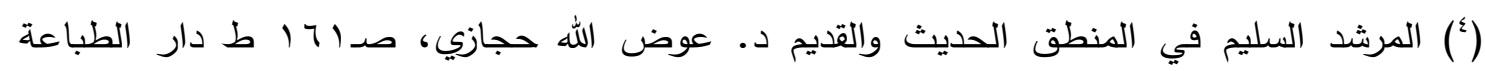
المحمدية بالقاهرة. 


\section{حولية كلية الدعهوة الإسلاهية بالقاهرة}

كعه فقه القيادة العسكرية من خلال قصة طالوت

سادسًا : ترجمت لبعض الأعلام، وذلك بالرجوع إلى كتب الطبقات والتراجم والتواريخ، كما قمت ببيان الكلمات الغريبة من كتب شروح السنة النبوية ومعاجم وقواميس اللغة. سـابعًا: اعتنيت بقواعد اللغـة العربيـة والإمـلاء, وعلامـات الترقيم, ومنهـا علامـات التتصسيص

$$
\text { بحسب المنهج الأكاديمي المتبع. }
$$

ثامنًا: قمـت بترتيب المصسادر والمراجـع في نهايـة البحث ترتيبا أبجديا, بادئاً باسم المُؤلَّف ثم

$$
\text { المؤلّف، مع الإشارة إلى رقم الطبعة وتاريخها ومكان الطبع إن وجد. }
$$

وقد اقتضت طبيعة العمل في هذا البحث تقسيمه إلى ثلاثة مباحث يندرج تحتها تسعة مطالب, تسبقها مقدمة فتواطئة, ثم زنَّلتها بخاتمـة تشتمل على أهم النتائج والتوصيات يتبعها ثبت المصـادر والمراجع فقهرست الموضوعات, وعلى هذا جاء البحث مرتَّاً على النحو التالي: عنوان البحث: فقه القيادة العسكرية من خلال قصة طالوت (دراسة تأصيلية) المبحث الأول: بين يدي القصة • المطلب الأول: جمال الدّلالة والسياق في القصة. • المطاب الثاني: التناسب السياقي في القصة. المبحث الثاني: العطاءات الإلهية في شخصية القائد المُلْهَم • المطلب الأول: الاصطفاء الإلهي. • المطلب الثاني: البسطة في الجسم. • المطلب الثالث: البسطة في العلم.

المبحث الثالث: المؤهلات القيادية في الثخصية الريادية 


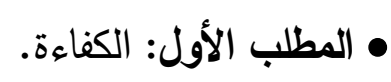

• المطلب الثاني: احترام ضوابط الاختيار •

• المطلب الثالث: الدراسة العسكرية وفن القتال.

• المطلب الرايع: ضبط النفس.

الخاتمة

أهم النتائج والتوصيات

ثبت المصادر والمراجع

فهرس الموضوعات

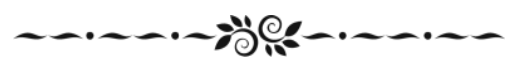




\section{تهرير أهم هصطاحمات عندان البحث}

أولا: مصطلح (فقةه القيادة)

إن المصطلح السابق يتكوَّن من كلمتين:

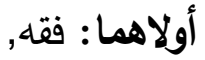

ثانيهما: القيادة

أما الفقـه في اللفة فهو: "العلم بالثـيء والفهم لـه, والفطنة, وغلب على علم الدين لشرفه"( '),

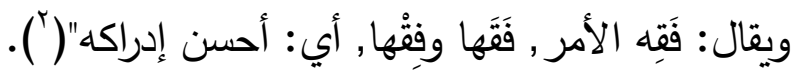

وأما في الاصطلاح فهو: "العلم بالأحكام الثرعية العملية المكتسب من أدلتها التفصيلية"("). و القيادة في اللغة:

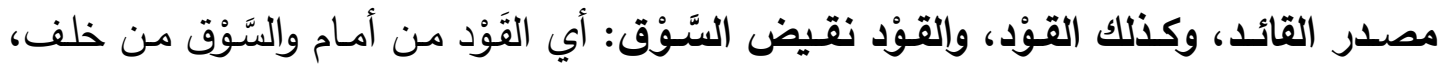
والقائد: واحد القواد والقادة، ويقال: القائدة من الإبل: أي التي تقدم الإبل وتألفها، والقائد من الجبل أي: أنفه. والأقواد من الناس: أي الذي إذا أقبل على الثئ بوجهه لم يكد يصرف وجهه عنه، وقاد الجيش قيادة: رَأَسَهاه ودَبَّر أمره، والانقياد: الخضوع، تقول: قُدْته فانقاد واستقاد لي( (َ).

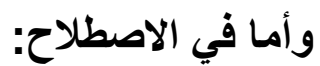

فعلى الرغم من أن موضوع القيادة من أهم مبادئ العلوم الإنسانية، إلا أنه لم يستقر رأي على

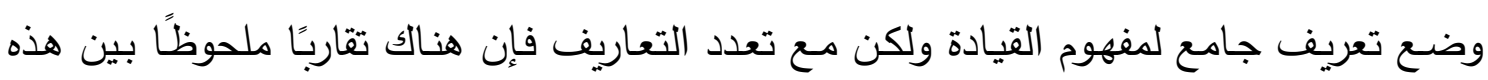
التعاريف، ومن أهم هذه التعاريف:

هي: "الفن الذي تستطيع بواسطته التأثير على توجيه الآخرين إلى هدف معين بطريقة تحصل بها على ثقتهم واحترامهم وطاعتهم وتعاونهم المخلص"( ) .

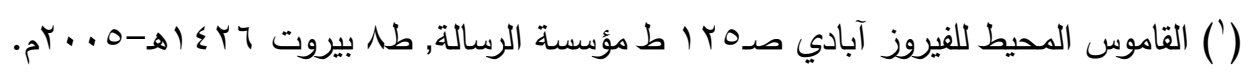

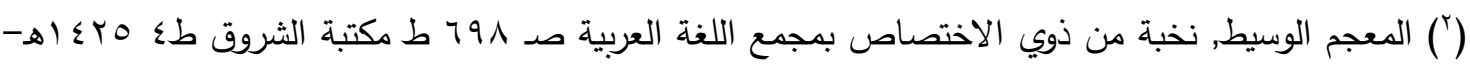

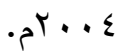
(r) الحدود الأنيقة والتعريفات الدقيقة للعلامة زين الدين أبو يحيى زكريا بن محمد بن أحمد بن زكريا الأنصاري

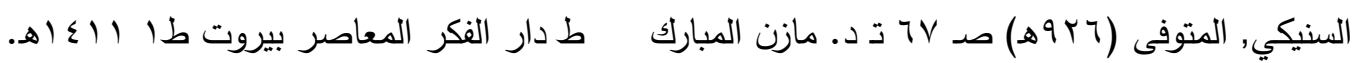

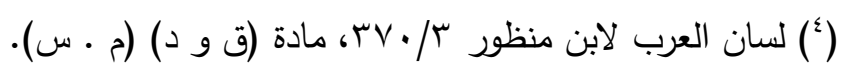

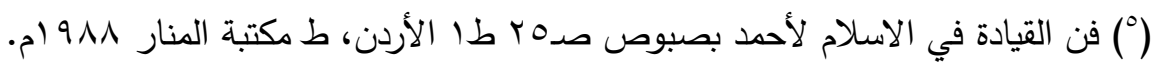




\section{حولية كلية الدعهوة الإسلاهية بالقاهرة}

كهيقفه القيادة العسكرية من خلال قصة طالوت

أو هـي: "ذلك السلوك الذي يقوم بـه شـاغل مركز الخلافة، أثناء تفاعله مـع غيره من أفراد الجماعة، فهي عملية سلوكية، وتفاعل اجتماعي فيه نشاط موجه ومؤثر، علاوة على كونه مركز أو قوة، والقيادة قبل ذلك مسؤولية"( ').

أو هي: "الجهد أو العمل الذي يمارسه شخص للتأثير في الناس، وجعلهم يتعاونون لتحقيق هدف يرغبون كلهم في تحقيقه"() (').

وعليـه: فإن فقـه القيـادة يعني: امتلاك القدرة بالتأثير على سلوك مجموعـة من الأفراد, وقد يكونون (شعبا- دولة- أمة) وتتسيق جهودهم وتوجيههم لبلوغ الغايات المنشودة بفهم وعلم وحسن إدراك.

ثانيا: مصطلح (القصَّة)

لغسة: الخَبَرَ, وهو القصص, يُقـال: قصَّ علي خبره يقصـه قصّــا, وقصصـا, والمعنى: أورده, والقصص: الخبر المقصوص, وتقصَّص كلامـه: حفظه, وتقصّص الخبر : تتبعه, وقصّ آثارهم يقصها قصا, وتقصصها: تتبعها بالليل, وقيل هو: تتبع الأثر في أي وقت كان, قال تعالى: دإ)...

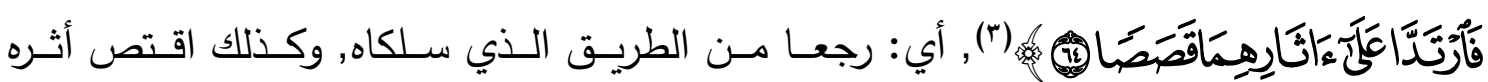
وتقصص, ويقصان الأثر , أي: يتبعانه(؛).

أمسا اصطلاحا: "فلفظ القصص أو القصّ أنسب لفظ مطلق على تلك الأنباء التي عرضـها القرآن الكريم, إذ إن ذلك أشبه بقص أثر الثيء وتتبعه, ثم الوقوف عليه بذاته لا على صورته أو ما يشبه صورته"(•), والقصة في القرآن الكريم هي: "واسطة بيانية تبليغية للوحي الإلهي, بغاية تجذير العقيدة, وتوطيد نظـام حيـاة متكامـل للإنسـانية, وتغييـر مـا بـالنفوس مـن جهالـة وشـرك

(') القيادة: الأسباب الذاتية للتمية القيادية لجاسم بن محمد مهلهل الياسمين صد ا طا ط دار الوفاء بالقاهرة

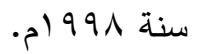

(†) الأنماط القيادية وعلاقتها بالأداء الوظيفي د. طلال عبد الملك الشريف صدّ؛ رسالة ماجستير بجامعة نايف

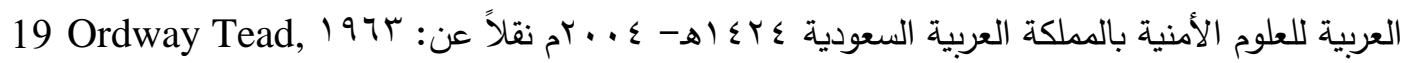

p. ،

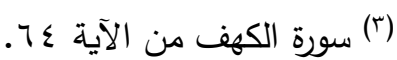

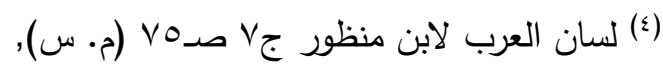

(0) القصص القرآني في منطوقه ومفهومه د. عبد الكريم الخطيب صده ط ط دار الفكر العربي, بيروت لبنان 


\section{حولية كلية الدعهوة الإسلاهية بالقاهرة}

كعرفة القيادة العسكرية من خلال قصة طالوت

وعبودية لغير الله تعالى, نزعت منزعًا واقعياً, فصدرت في الأغلب من مرجعيات تاريخية ارتبطت

بسير الأنبياء والرسل في أزمنة غابرة, وبأخبارهم وصراعاتهم من أجل رسالات الله تعالى"('). وعليه: يمكن تعريف القصسة أنها: سرد تاريخي موثق عن أخبار السـابقين بغاية أخذ العبرة

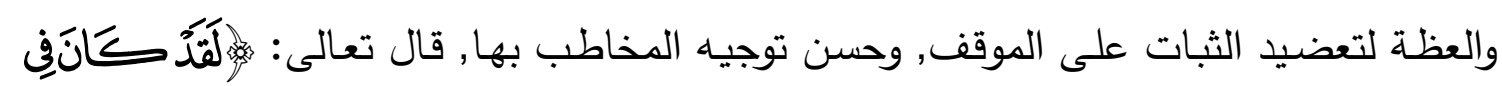

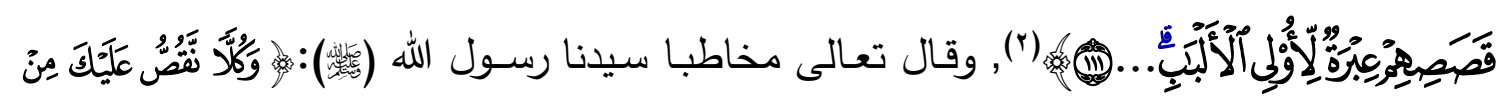

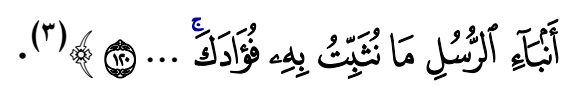

ثالثا: مصطلح (دراسة تأصيلية) إن المصطلح السابق يتكوَن من كلمتين:

أولاهما: دراسة.

ثانيهما: تأصيلية.

أما الدراسة في اللغة: "فتدور مادة دَرَسَ في اللغة حول الخفاء, يقال: الدال والراء والسين أصل واحد يدل على خفاء وخفض وعفاء "فالدرس: الطريق الخفي, يقال درس المنزل: عفا, ومن الباب الدريس: الثوب الخلق, ومنـهـ درست المرأة: حاضـت .., ودرست الحِنْطـة وغيرهـا في سنبلها: إذا دستها, فهذا محمول على أنها جعلت تحت الأقدام, كالطريق الذي يدرس ويمشى فيه"(؛), ويقال:

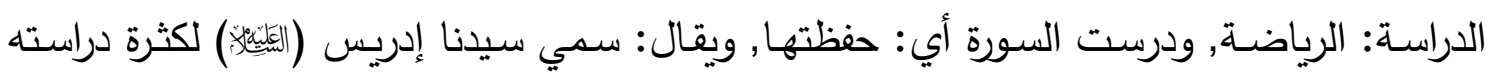
كتاب الله - تعالى"(•), والمِدراس: الموضع يقرأ فيه القرآن"("), وعليه: فإن دراسة الموضوع أو القرآن أو غيرهما تكون بمعنى: المداومة والتكرار , مما يترتب على ذلك من الحفظ والاستذكار . وأمـا الدراسـة في الاصطلاح: فإن دَرَسَ فعل وردت مشتقاته اللفظية بجميع صيغها في معاجم

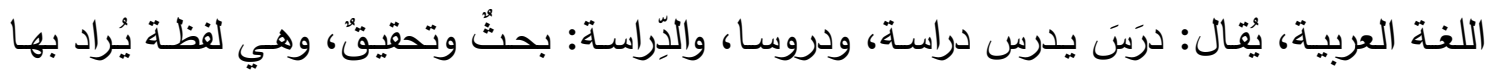

(') الخطاب القرآني, سليمان عشراني, ديوان المطبوعات الجامعية الجزائر صدVا 99 (ام.

(r) (r) سورة يوسف من الآية 11)

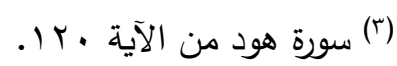

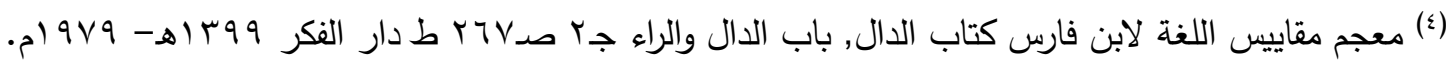

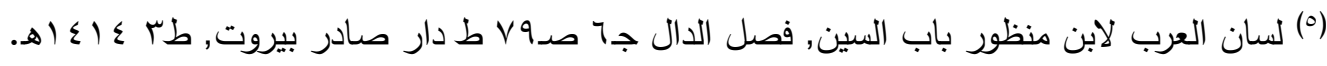
(آ) القاموس المحيط للفيروز آبادي, باب السين فصل الدال صدء ؛ه ط ^ ط مؤسسة الرسالة بيروت لبنان . 
كعبقه القيادة العسكرية من خلال قصة طالوت

العديد من المعاني اللغوية، يُقال: درس, أي: أقبل على كتاب أو علم ونحوهما يحفظه، وأيضا: ركَّز

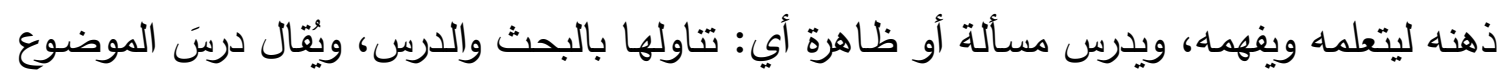

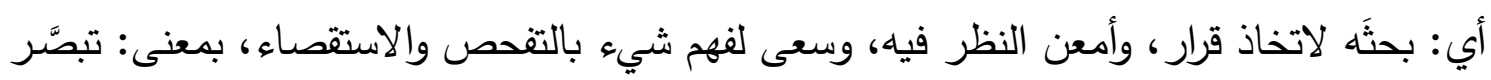

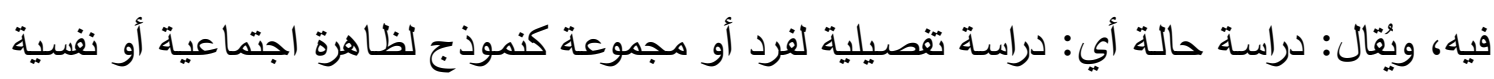
أو غيرهما، والدراسات الاجتماعية تعني: مجموعة علوم تتضمن علم المالية الاجتماع والتاريخ وغيرهما

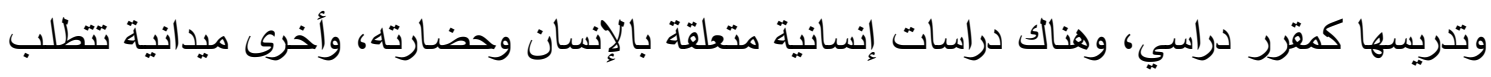

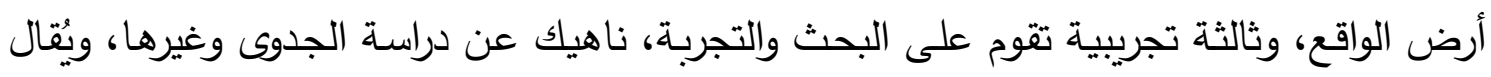

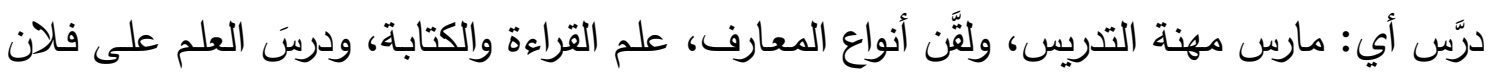

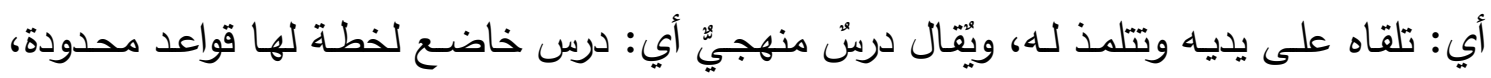
قائمة أبحاثه على خطة منهجية (1). والتأصيل في اللفـة: تأصيل الثيء: جَعُلْه ذا أصل ثابت, راستخ ذو جذور , قال ابن فارس:

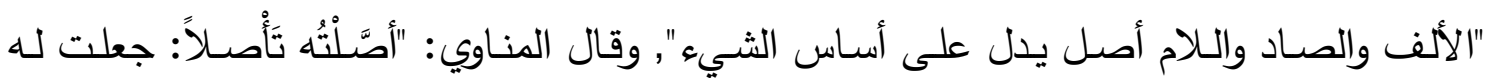

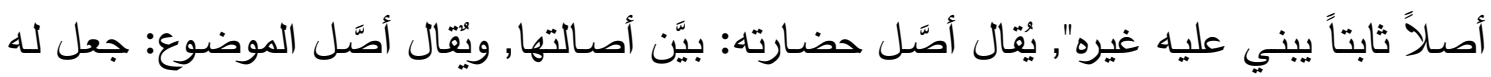

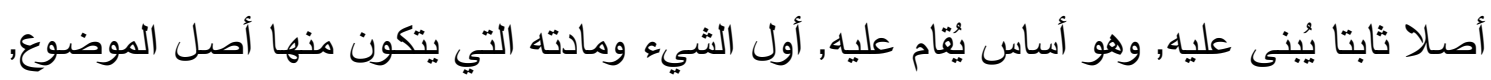

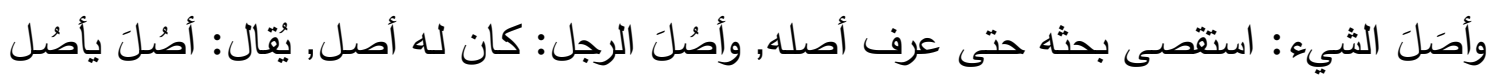

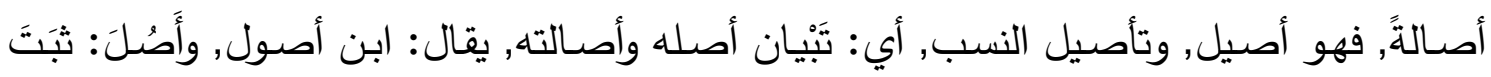

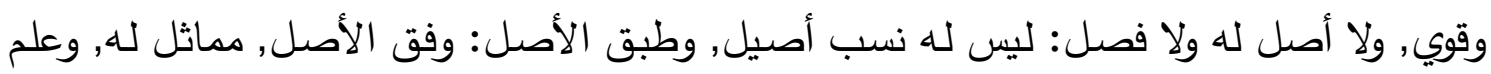

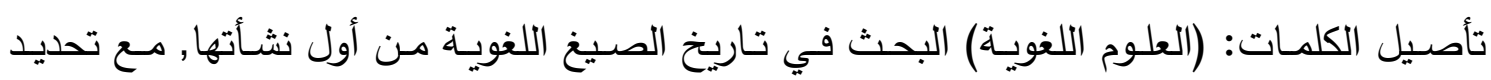

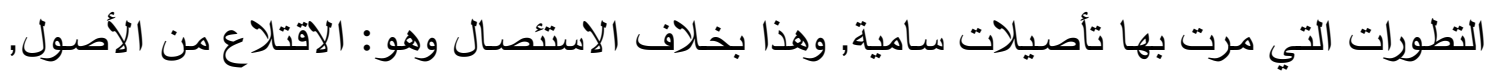

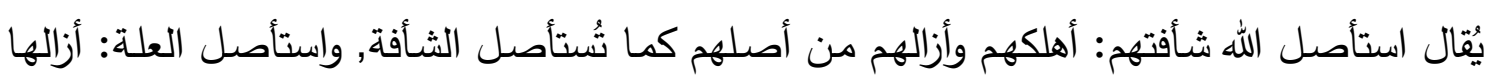

(1) يُنظر في هذا: معجم مقاييس اللغة للعلامة أبي الحسن أحمد بن فارس بن زكريا القزويني الرازي المتوفي

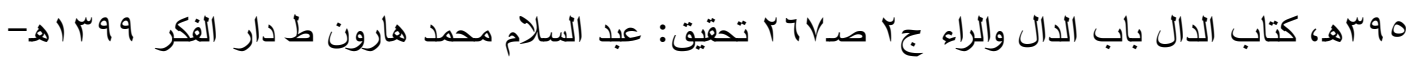

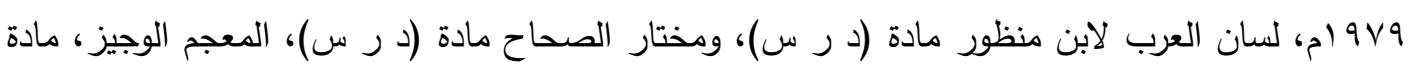

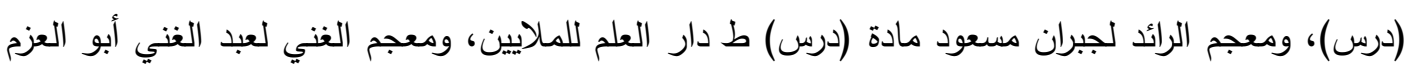

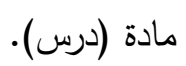




\section{كعه فقه القيادة العسكرية من خلال قصة طالوت}

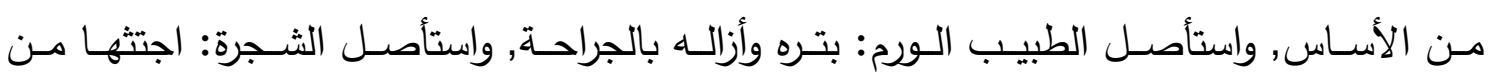

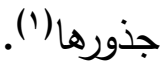

أما التأصيل في الاصطلاح فهو: "جعل الثيء ذا أصل ثابت له قواعد وأصول, ومناقشة هذه القواعد والأصول من أجل البقاء على الأصل الثابت, ولذلك نجد العديد من أنواع التأصيل, فهناك مثلا: التأصيل الدعوي, التأصيل الفقهي, التأصيل اللغوي, التأصيل القانوني, التأصيل العلمي..إلخ, ومن هذا المنطلق فإن التأصيل الدعوي - ما يههنا هنا- وهو ما يُطلق ويُراد به: "بيان الأصل من

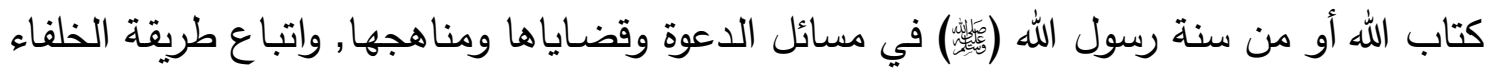

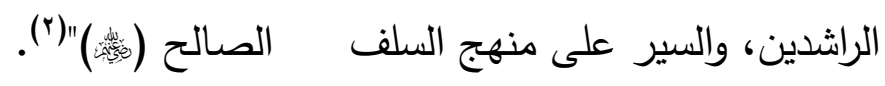
وعليه: فإن الاراسة التأصيلية تعني: تناول الموضوعات أو القضايا انطلاقا من أصلها الثابت بإرجاع القول والفعل إلى أصل وأساس يقوم وينىى عليه, مع ما يلائمهما من أدلة نصية أو قواعد

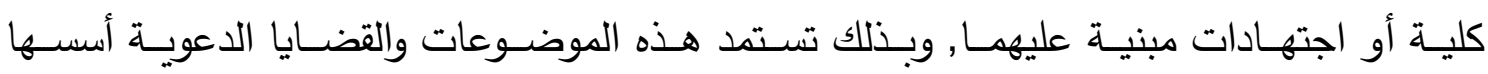
ومنطلقاتها مـن الشـريعة الإسـلامية ولا تتعـارض في تحليلاتهـا ونتائجها وتطبيقاتها مـع الأحكام الثـرعية ومناهجها, وهذا يعني تتـاول الجانـب التأصـيلي والتقعيدي للموضـوع, وتأصـيل مسـائله وقواعده ومناقشتها ووضع الضوابط لمعالجة نواحي التقصير •

(') يُنظر في هذا: معجم مقاييس اللغة للعلامة بن فارس (أصل), لسان العرب مادة (أ ص ل)، ومختار

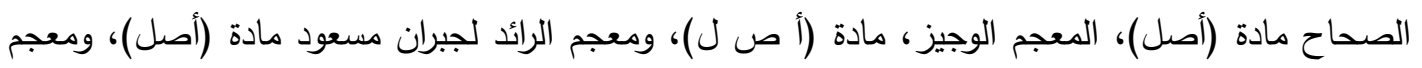

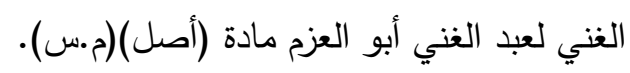

(r) انظر مقدمة: "عبد الكريم زيدان ومنهجه في التأصيل الدعوي من خلال كتابه أصول الدعوة" رسالة ماجستير

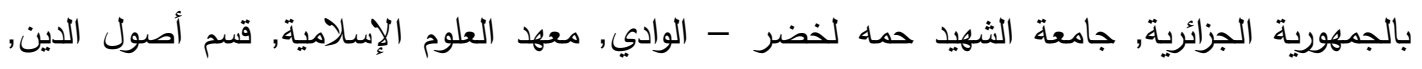
تخصص: دعوة وإعلام, للباحثة: برتيمة حكيمة, إثراف الأستاذ: مصطفى الثريف بلقاسمي, تاريخ المناقثة

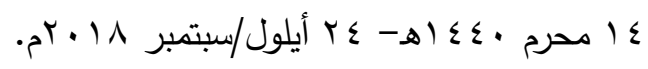




\section{حولية كلية الدعوة الإسلامية بالقاهرة}

كهِفقه القيادة العسكرية من خلال قصة طالوت

\section{تواطئة}

إن قصة القائد الُْْلْهَم (طالوت) سيقت ليستفيد منها القادة بالأخص, وكلما أرجعنا البصر إليها

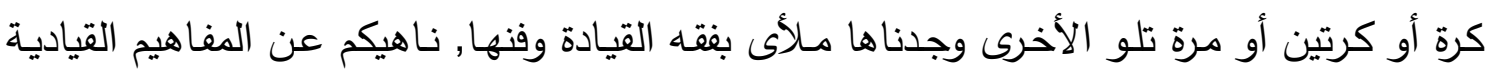

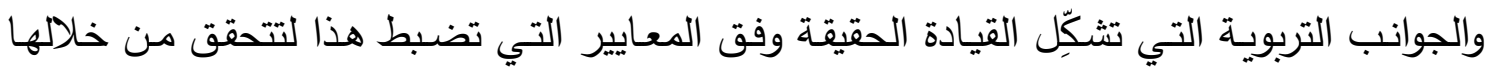

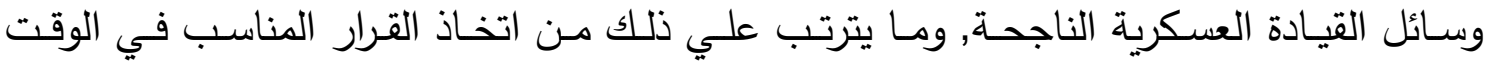

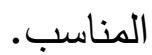

والحقيقة: أن عصر القائد (طالوت) يمثل الانطلاقة الحقيقية والنهضة الجماعيّة والرؤى القياديّة

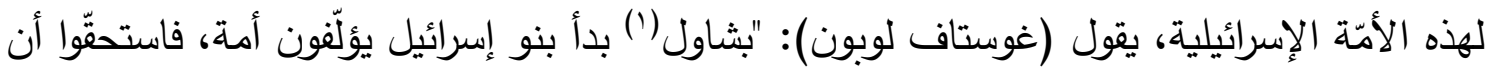

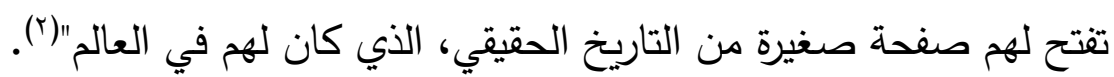
ولم تكن قيادة القائد طالوت لأمّة بني إسرائيل في تلك الفترة بالأمر العادي -إن جاز التعبير -

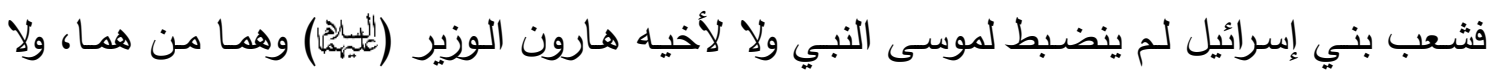

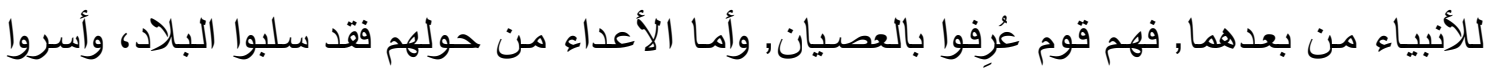

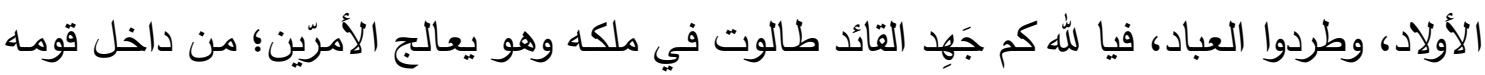
وعشيرته، ومن شرّ عدوّه وسطوته.

لقد كـان القائد (طـالوت) أنموذجـاً قرآنياً فذّاً للقـادة الصـالحين العظـام، الذين حملوا العقيدة الصافية، والتزموا المسار الصحيح، وحدّدوا الهدف الكبير، ولم يلتفتوا إلى عراقيل الطريق، وانطلقوا

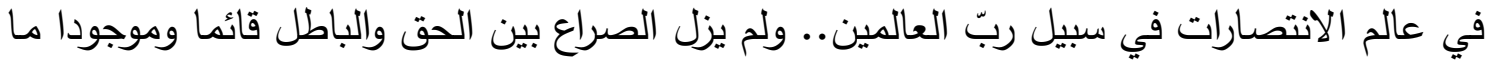

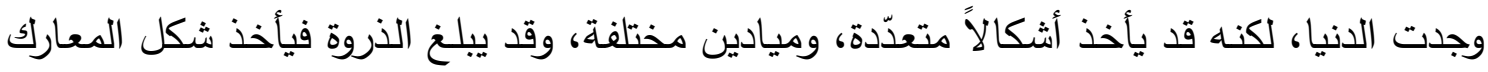

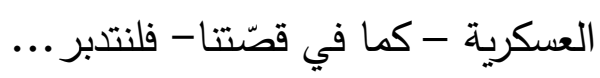

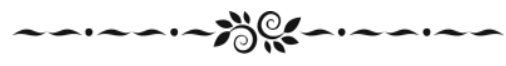

(') شاول هو أول ملك لبني إسرائيل وأحد شخصيات العهد القديم, وقد ورد ذكره في القرآن الكريم باسم طالوت.. وهو شخصية هذا البحث.

(†) اليهود في تاريخ الحضارات الأولى لغوستاف لوبون صده ترجمة: عادل زعيتر ، تحقيق: محمود النجيري طا

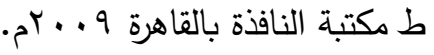




\section{المبـث الأول \\ (بين يدي القصةة)}

$$
\text { ويشتمل على مطلبين: }
$$

• المطلب الأول: جمال الدّّلالة والسياق في القصة. • المطلب الثانى: التناسب السياقى في القصة. 
كعبقه القيادة العسكرية من خلال قصة طالوت

إنـه من المؤكد أن القصـة القرآنية إنما ترد في سياق السور أو السورة الواحدة لتؤدي وظيفة فيها، وترسم غرضا معيَّنا, وغالبا ما يرد من القصة ما يناسب موضوع السورة ومحورها وأهدافها، وهذا مظهر واضـح من مظاهر وحدة السورة وتناسب معانيها ('), ولقد سعى هذا المبحث إلى الكثف عن القيمة الفنية والجمالية لمصطلح كثر تداوله مع غيره من المصطلحات على صفحات كتب المفسـرين، والأدبـاء، والبلاغينين، والنقـاد، والمهتمـين بالدراسـات التفسيرية واللغويـة والأدبيـة

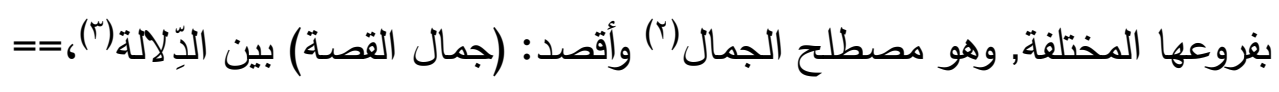
===والسياق(؛), وكذا التتاسب السياقي بين أجزاء القصـة الواحدة وبين القصـة والسورة, مما يُظهر مدى قوة الإعجاز البلاغي والبياني للقرآن الكريم بين كلماته وآياته وسوره.

(') التتاسب البياني في القرآن لأحمد أبو زيد, صد V7 ط مطبوعات جامعة محمد الخامس بالرباط ب99 ام.

(r) تدور الدلالة المعجمية لمادة (جَمُلَ) حول عدد من المعاني الثرية، غير أن الدلالة التي نعنيها في هذه (النها

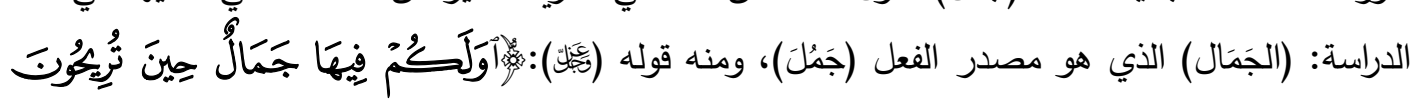

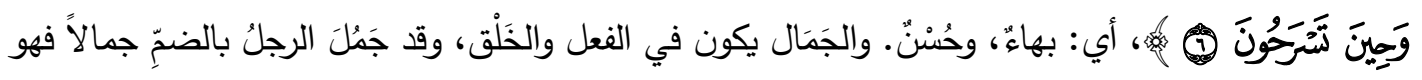

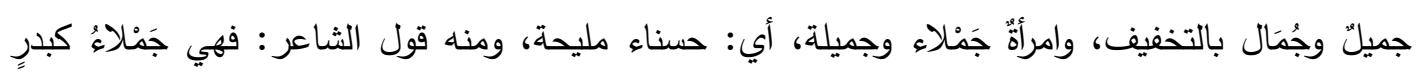

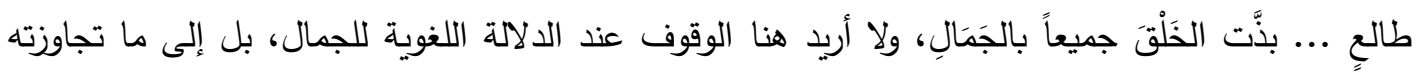

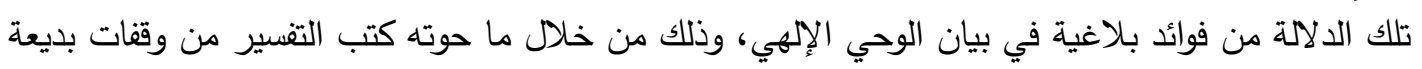

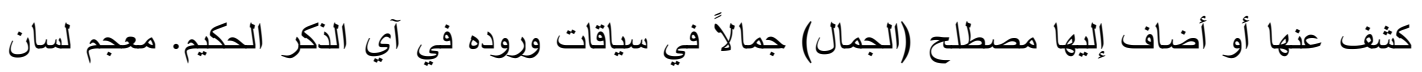

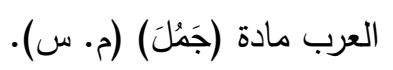

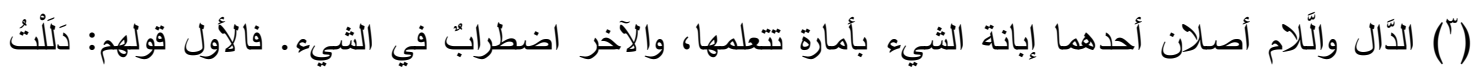

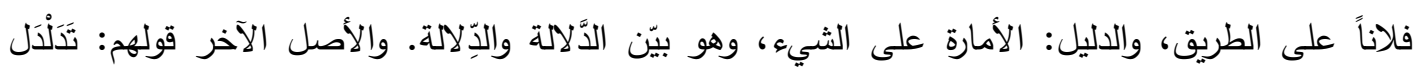

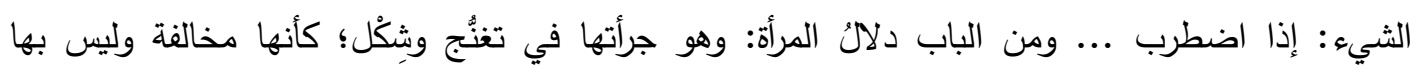

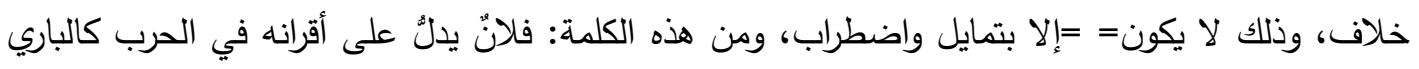

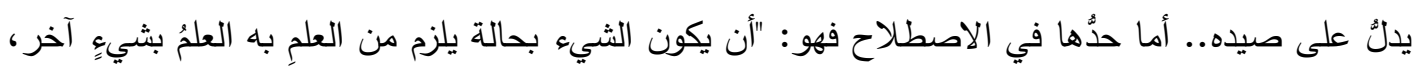

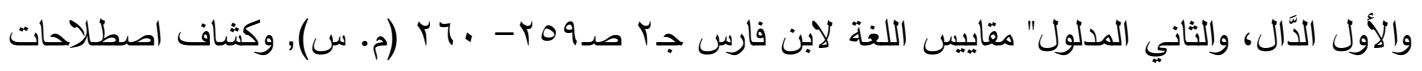

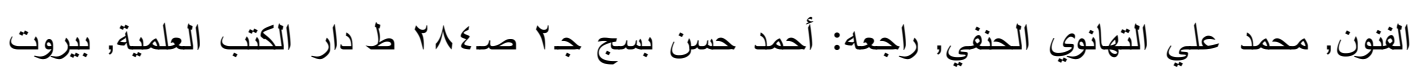
$.519 \times 1$

(4) أما (السياق) فيعني في الدلالة المعجية: "حدؤ الثيء، يقال: سقتُ إلى امرأتي صداقها، وأسقته, والسَّوْق

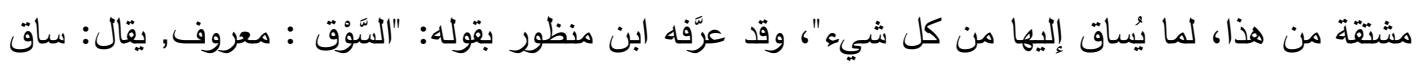

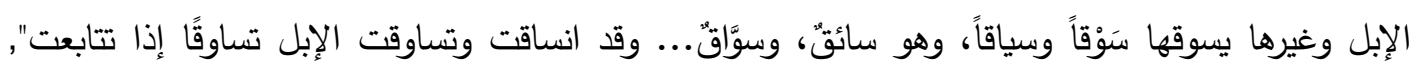


كهرفقه القيادة العسكرية من خلال قصة طالوت

ولما كان التأثير مطلباً رئيساً في كل كلام أدبي أولاه البلاغيون عنايتهم، حتى جعلوا المعجز

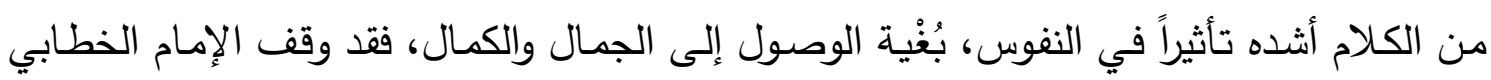

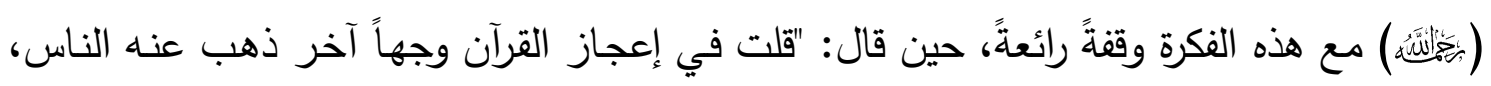

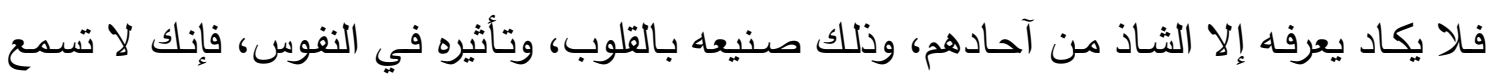

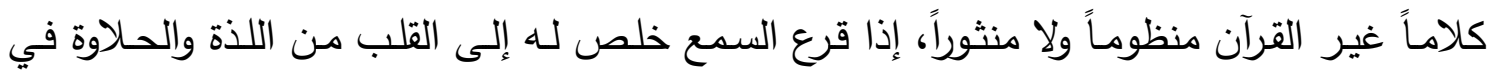

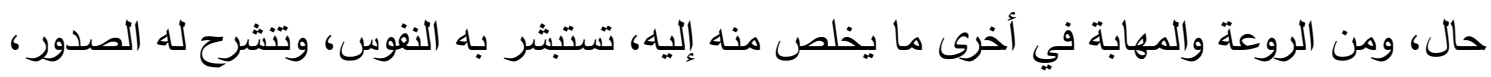

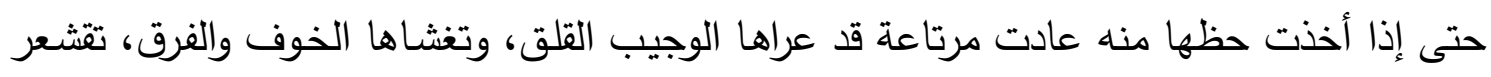

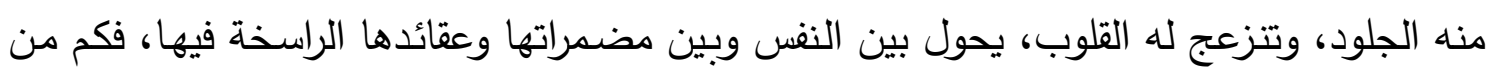

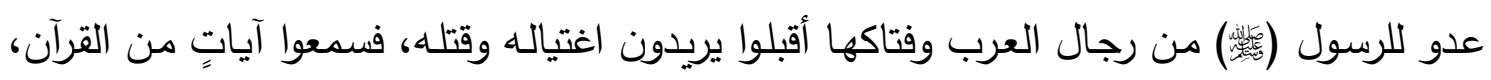

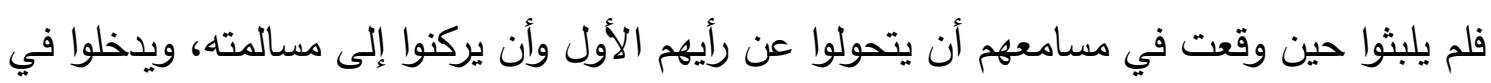

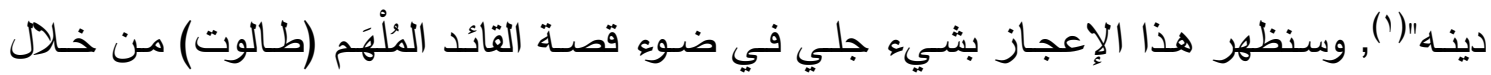
المطلبين الآتيين:

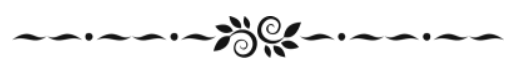

والسياق في الاصطلاح عند البلاغيين والنقَّاد له دلالات مختلفة: فيكون بمعنى الغرض، ويكون بمعنى الظروف والمواقف والأحداث التي ورد فيها النص، ويكون بمعنى السياق اللغوي الذي يمثله الكلام في موضع النظر أو التحليل، ويشمل ما يسبق أو يلحق به من كلام يمكن أن يضيء دلالة القدر منه (موضع التحليل)

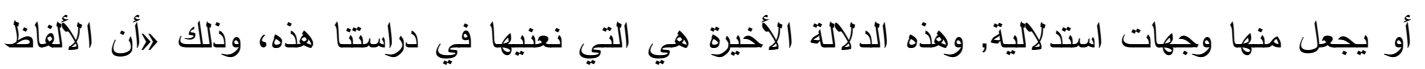

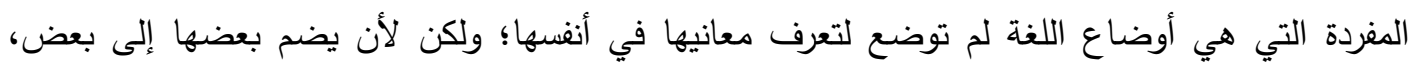

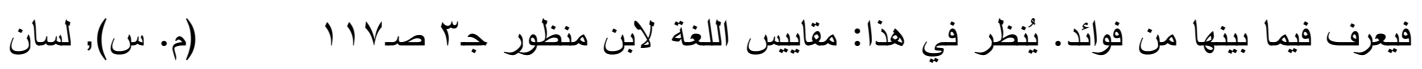

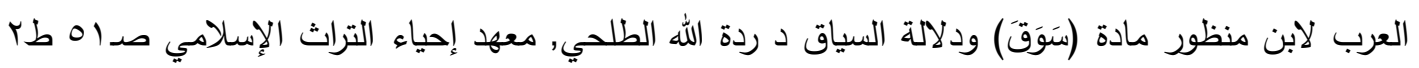

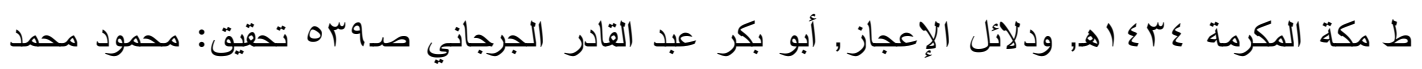

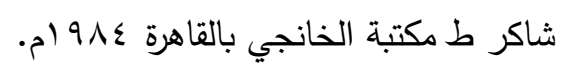

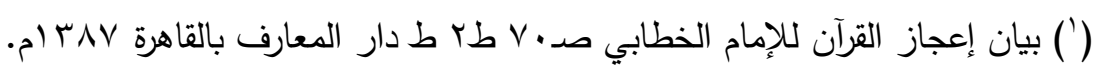


كع فقه القيادة العسكرية من خلال قصة طالوت

\section{المطاب الأول \\ جمال الدلِّالة والسياق في القصة}

لقد بُنيت قصة طالوت بناء مُحكماً من لبنات الحقيقة المطلقة، التي لا يطوف بحماها طائف

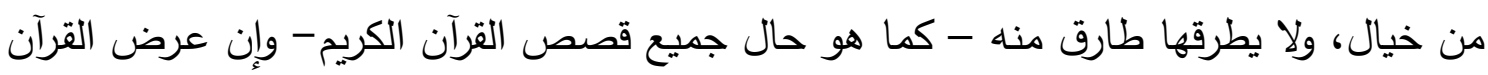

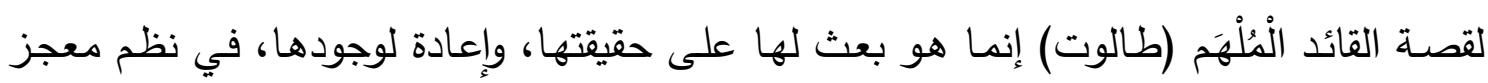

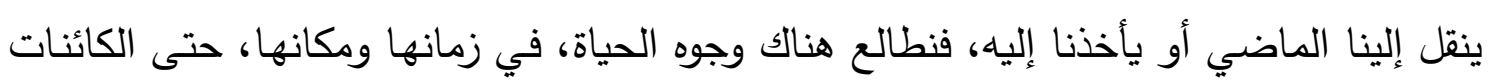

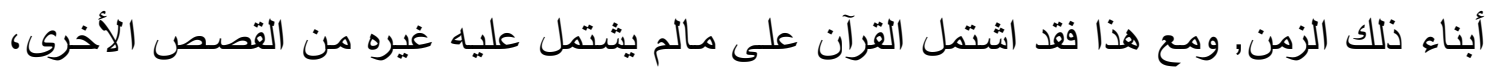

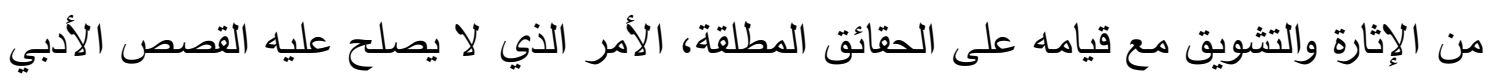

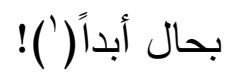

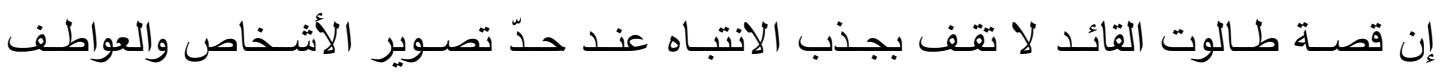

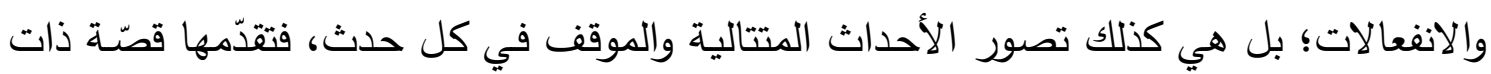

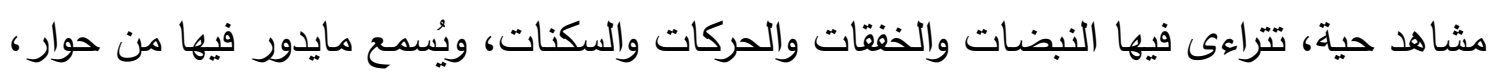
ومايتردد فيها من حديث ورأي، ومايقع من صواب أو خطأ، حتى يخيّل إليك أنك أحد أبطالها

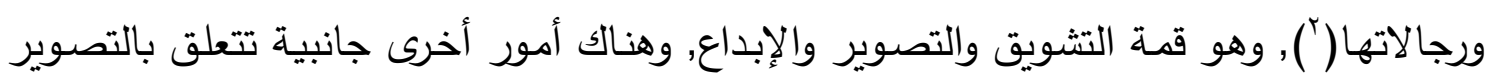

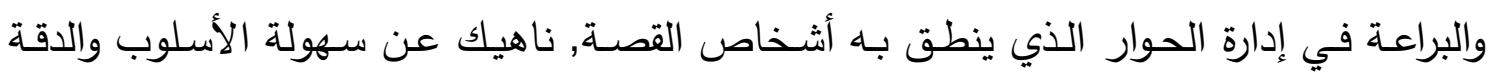

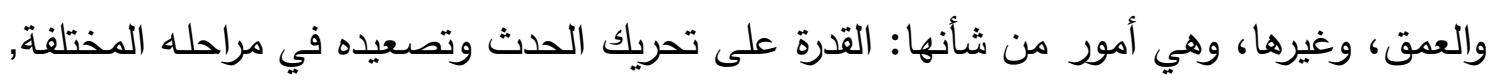

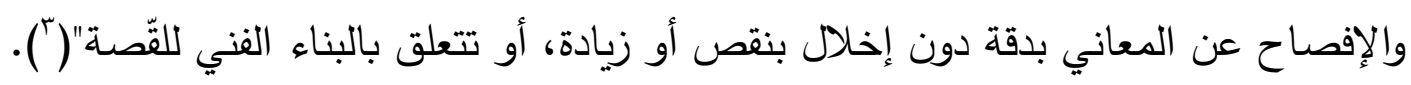

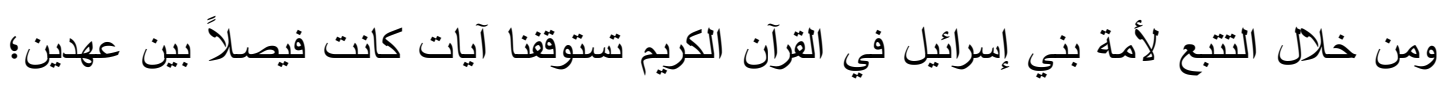

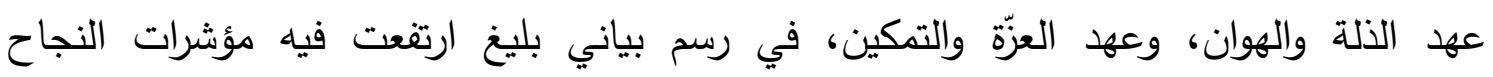

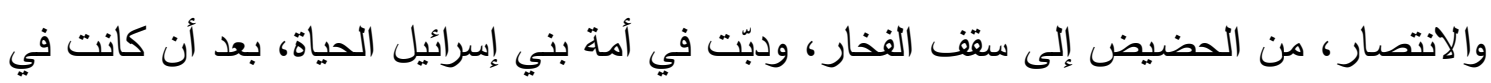

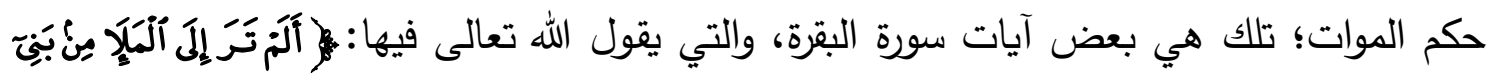

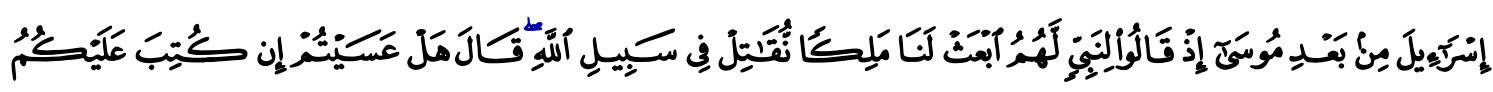

(') القصص القرآني في منطوقه ومفهومه لعبد الكريم الخطيب صد.ع-qء طب بيروت ط دارالمعرفة . $19 \vee 0-81490$

(r) النظم القرآني في آيات الجهاد لناصر بن عبد الرحمن بن ناصر الخنين صدץءه

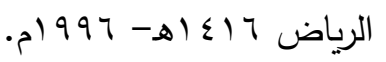

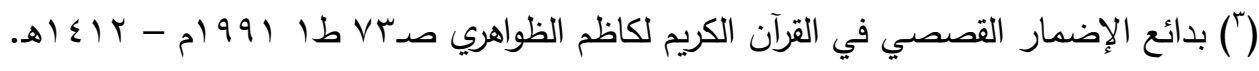


كعفقه القيادة العسكرية من خلال قصة طالوت

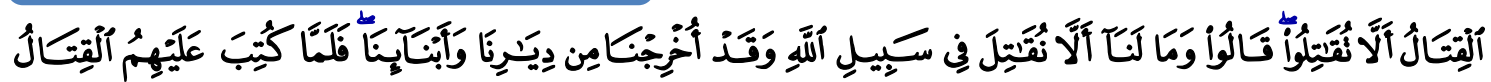

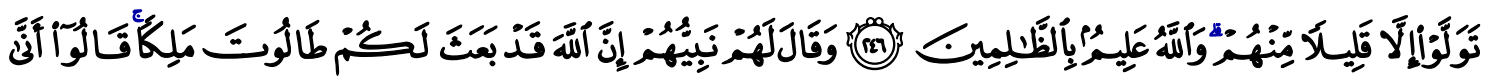

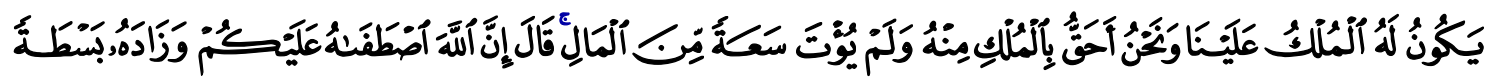

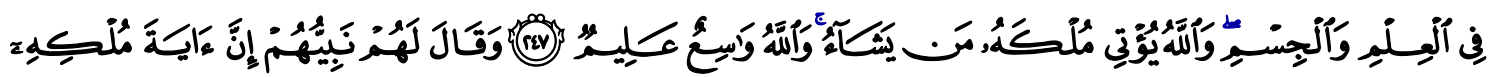

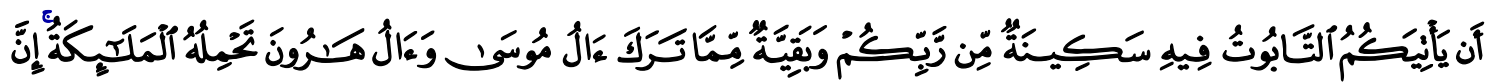

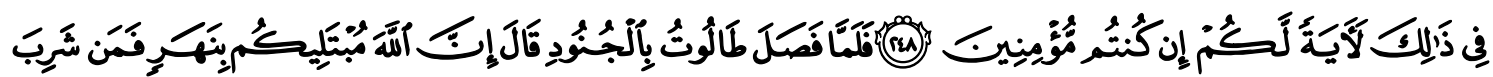

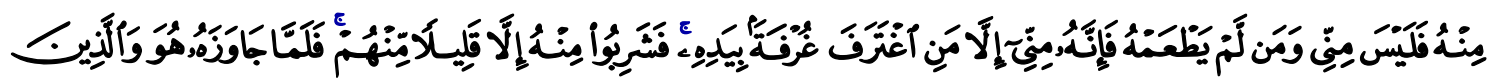

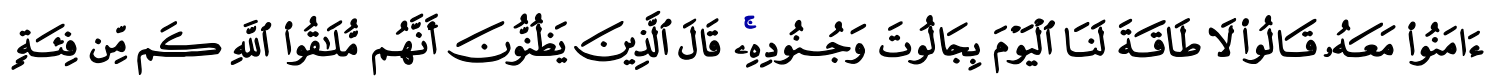

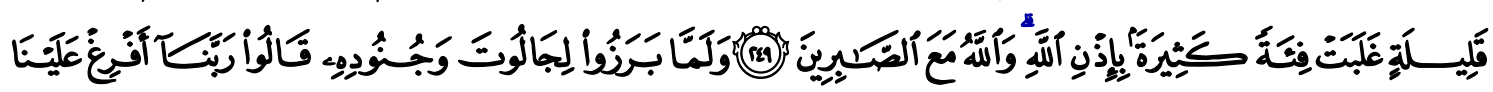

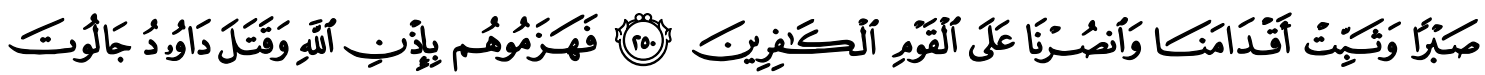

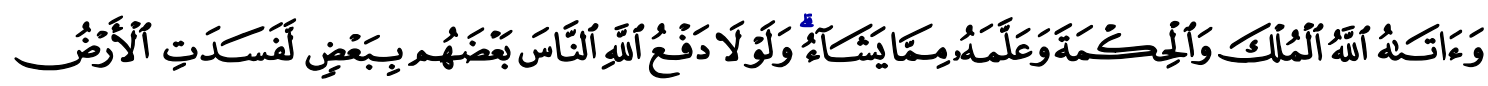

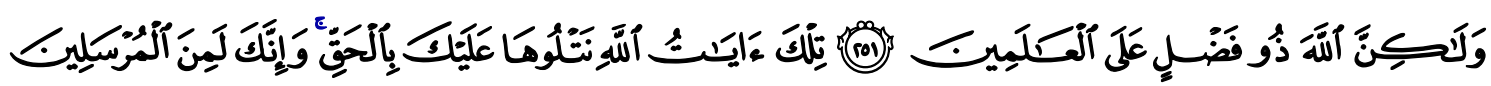

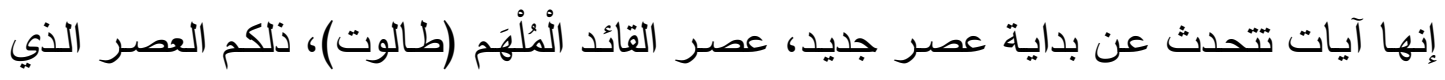

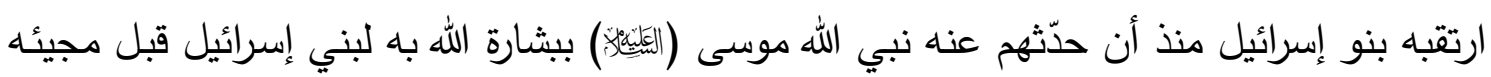

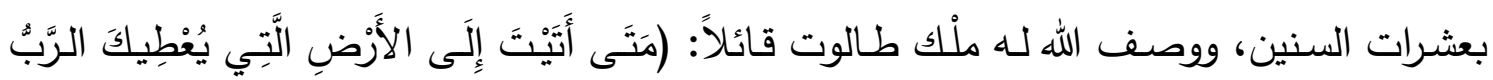

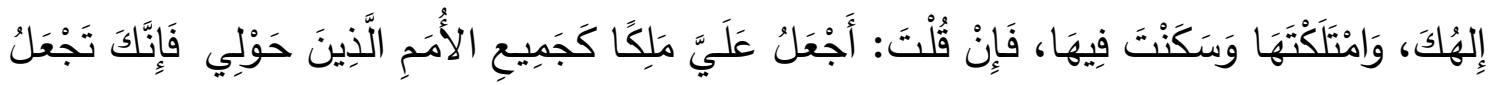

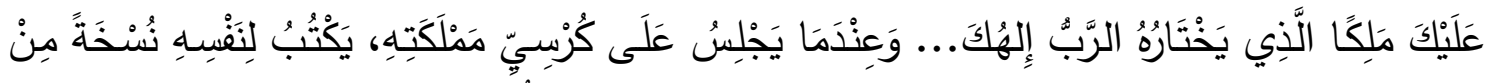

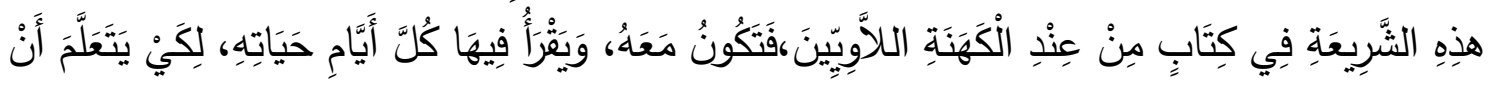

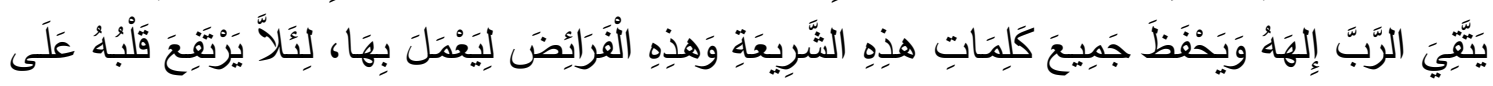

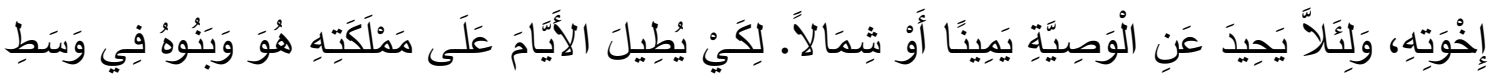
إِإِرَائِيلَ)(

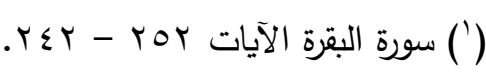

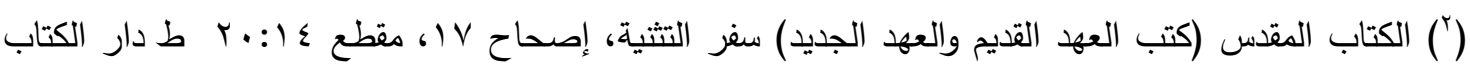




\section{هولية كلية الدعوة الإسلاهية بالقاهرة}

كعه فقه القيادة العسكرية من خلال قصة طالوت

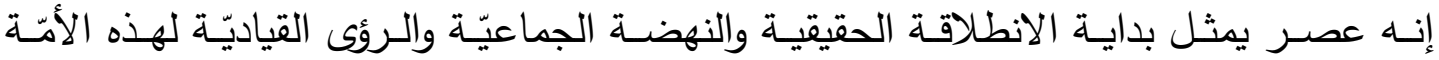
الإسرائيلية، يقول (غوستاف لوبون): "بثـاول بدأ بنو إسرائيل يؤلّفون أمـة، فاستحقّوا أن تفتح لهم

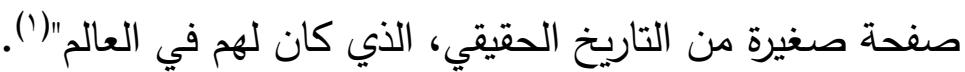

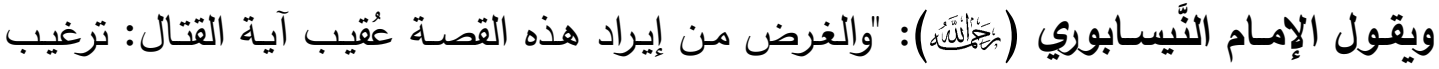
المكلَّين على الجهاد, وأن لا يكونوا كمَن أُمروا بالقتال فخالفوا وظلموا"(؟), فالسياق ليس شيئًا خارجاً تُعرض عليه النصوص أو الجُمل الملتبسة لتحظى بالتفسير الدلالي، أو التوجيه الإعرابي فحسب،

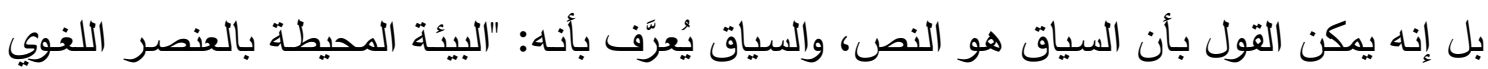

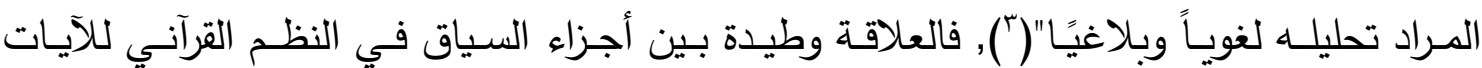
الكريمة, فمن شأن هذا إيجاد حمال بين الدِّلالة والسياق.

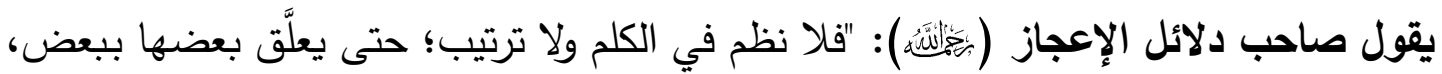
ويُبنى بعضها على بعض، وتجعل هذه بسببٍ من تلك"(๕), ولذلك كثيرا ما نرى الإمام ابن عاشور

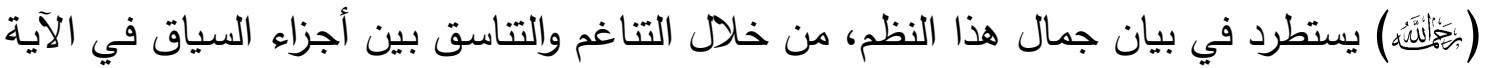
الواحدة أو الآيات، حين تحدث عن ردّ العجز على الصدر في السياق، قبل وبعد الآية الكريمة(ْ)". ولذلك يُعرَّف علم المناسبة بأنـه: "علمُ تعرف منـه علل الترتيب، وثرته الاطلاع على الرتبة التي يستحقها الجزء بسبب ما له بما وراءه وما أمامه من الارتباط والتعلق الذي هو كلحمـة النسب.

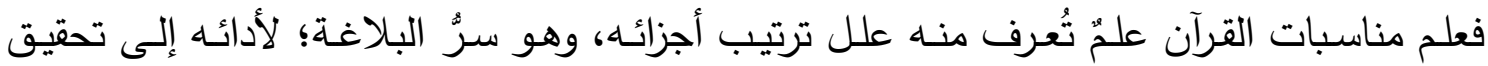
مطابقة المعاني لما اقتضاه الحال"( ). فإذا كانت البلاغة تبحث عن عللٍ عملية في حال المتكلم أو المخاطب أو سياق الكلام، وهي

$$
\text { (') اليهود في تاريخ الحضارات الأولى لغوستاف لوبون صدءه (م. س). }
$$

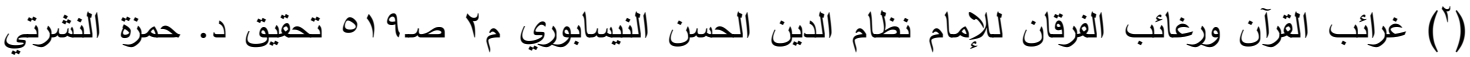

$$
\text { وآخرون, ط بدون. }
$$

(ץ) وإن كانت هناك أنواع أخرى من السياق لها تأثير مباشر على النصوص، كالسياق الثرعي، والنحوي، والنفسي

$$
\text { والاجتماعي وغيرها. }
$$

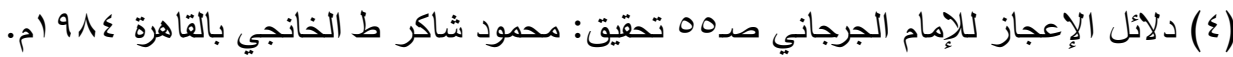

(0) انظر مثلا: التحرير والتتوير للإمام الطاهر بن عاشور ج؟ صدV VA -VV دار سحنون, تونس.

(1) نظم الدرر في تتاسب الآيات والسور للإمام برهان الدين البقاعي جا صده-؟ ط دار الكتب العلمية طץ

بيروت 0 ا عـ اهـ. 


\section{حولية كلية الدعوة الإسلاهية بالقاهرة}

كهيفه القيادة العسكرية من خلال قصة طالوت

العوامل الثلاثة التي جُمعت تحت اسم "مقتضى الجمال"(')، فإن ذلك يبرز في مراعاة السياق أو الو فالعيات

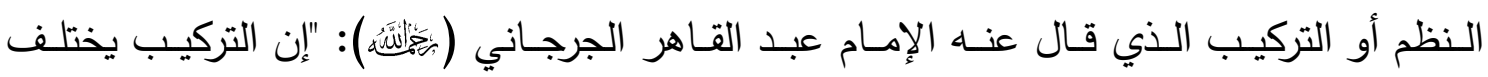

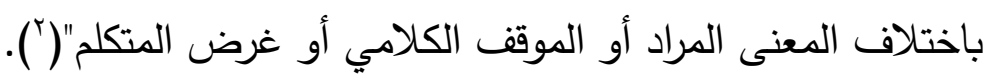
إن النظم في السياق القرآني يُعدُّ تنامياً طبيعياً نتيجة الربط المعجز بين الآيات القرآنية، بل تجاوز المعنى المعجمي لمصطلح الجمال إلى إيجاد علاقة وطيدة تربط بين أجزاء الآيات جميعاً

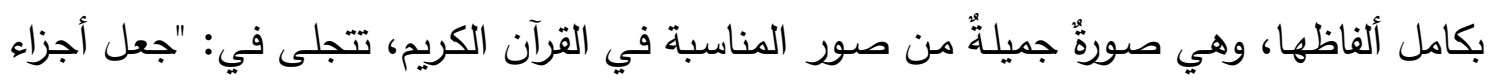
الكلام بعضها آخذاً بأعناق بعض، فيقوى بذلك الارتباط، ويصير حاله حال البناء المحكم، المتلائم

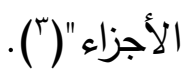

لقد أورد الدكتور محمد أبو موسى (مثله) نقلاً عن أحد العلماء، ما يُعدُّ منهجاً ينبض، ونبراسًا

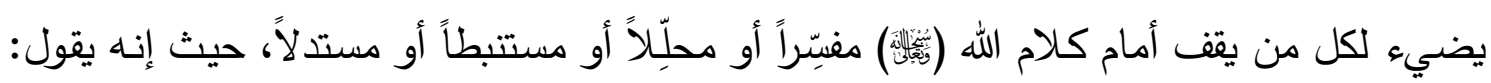

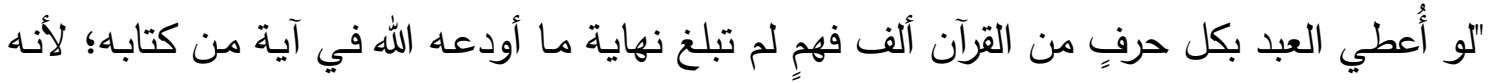

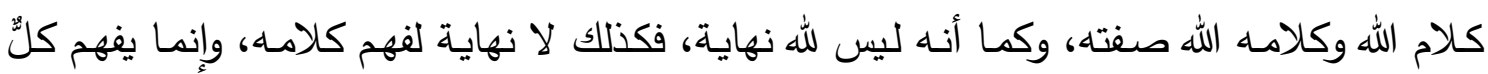
بمقدار ما يفتح الله عليه"( (أ)..

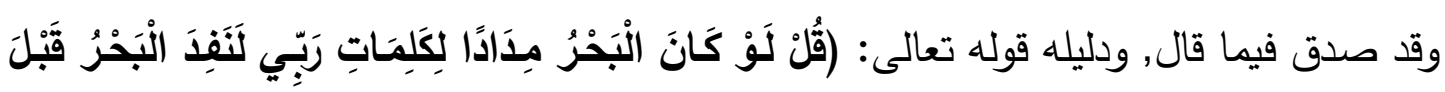

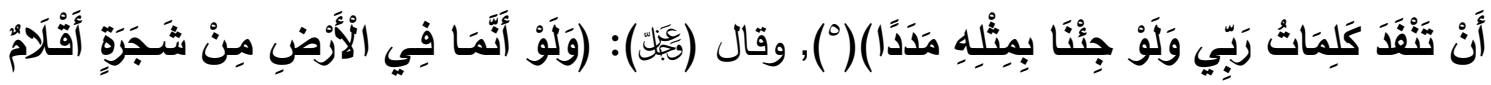

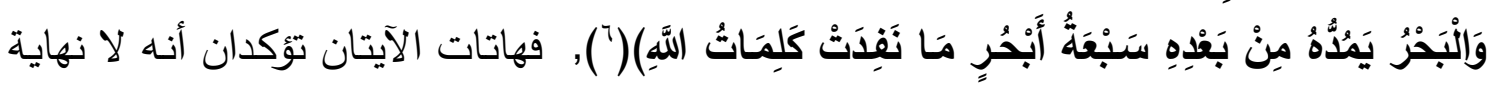

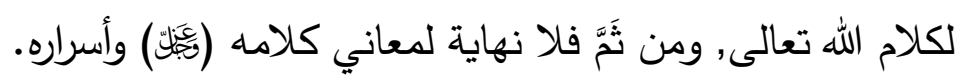

(1) اللغة والإبداع (مبادئ علم الأسلوب العربي) د. شكري محد عياد صداب ط مكتبة الأنجلو طا القاهرة .5191 .

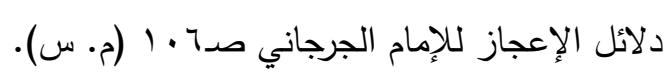

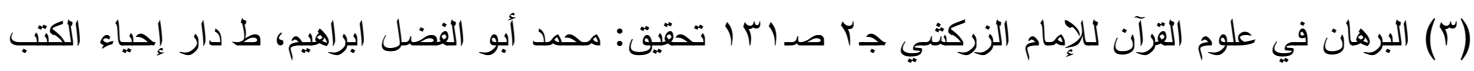

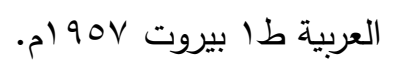

(ع) من أسرار التعبير القرآني (دراسة تحليلية لسورة الأحزاب) د. محمد محمد أبو موسى صدء ط مكتبة وهبة

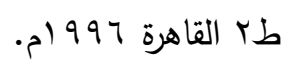

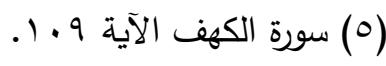

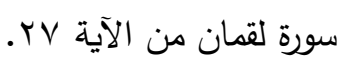


كهيقفه القيادة العسكرية من خلال قصة طالوت

والخلاصة: إن جمال الدلالة في قصة طالوت هي صورة من صور الإعجاز القرآني التام الذي قال عنه الإمام الخطابي (بِّئُ) ): "اعلم أن عمود هذه البلاغة التي تجمع لها هذه الصفات هو وضع كل نوع من الألفاظ التي تشتمل عليها فصول الكلام موضعه الأخص الأشكل باه، الذي إذا أبدل مكانه غيره جاء منه إمـا تبدل المعنى الذي يكون منه فساد الكلام، وإما ذهب الرونق الذي يكون منه سقوط البلاغة"(') من (')

فورود الألفاظ القرآنية بهذه الدقة، ومناسبتها المعاني المرادة منها، مع الربط بين أجزائها, من أبرز خصائص جمال التعبير القرآني؛ ولذلك عدّه علماء الإعجاز وجهاً مهماً من أوجه الإعجاز في ألفاظه بين الدّلالة والسياق, وهو رأيٌٌ سديدٌ في الإعجاز ، وهو لا يتعارض مع القول بأن إعجاز القرآن في نظمه، بل هو هو، فالقرآن الكريم بما في نظمهه من إثارةٍ للنفوس والمشـاعر احتل تلك المكانة من البلاغة التي فاق بها بلاغة البلغاء، والبحث في الإعجاز لا يعدو كونه بحثاً عن مأتى هوي تلك الإثارة، وذلك التأثير الجمالي المحض.

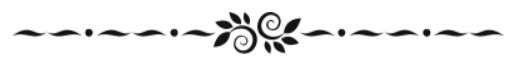




\section{حولية كلية الدعهوة الإسلامية بالقاهرة}

كهيعفه القيادة العسكرية من خلال قصة طالوت

\section{الاطبل الثاني \\ التناسب السياقي في القصة}

إن القصة القرآنية ليست رواية تاريخية إنما هي ذات هدف، والقرآن الكريم لم يتبع في حديثه

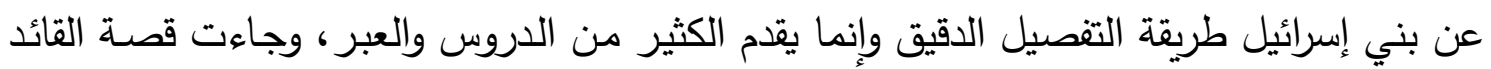
طالوت لمعالجة قضية فقه القيادة وتعزيز عوامل النصر التي توصل إلى العزة والمكانة ولو كانوا

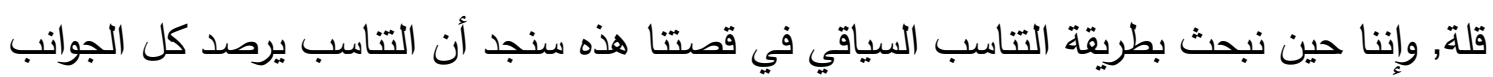

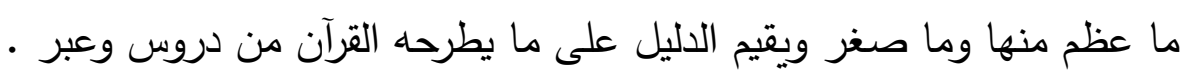

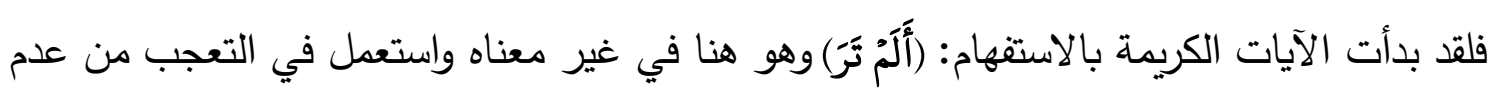
علم المخاطب بمفعول فعل الرؤية، ويحتمل أن يكون تقريريا أو إنكاريا(')، وهؤلاء الملأ قالوا بعد فئاه

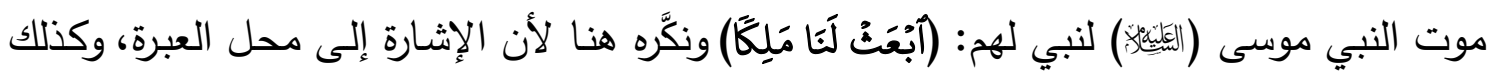
لم يقل نبيهم لأن هذا النبي لم يكن معهودا عند السامعين حتى يعرف لهم بالإضافة (بال). وقد وردت كلمتي الجهاد والقتال مترادفان في آيات كثيرة غير أن القرآن في آيات عديدة يفيد أن

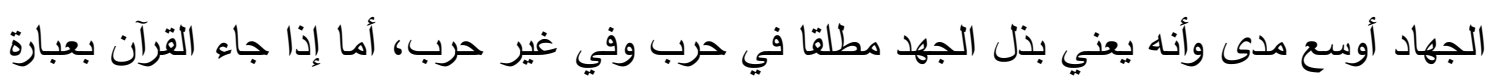

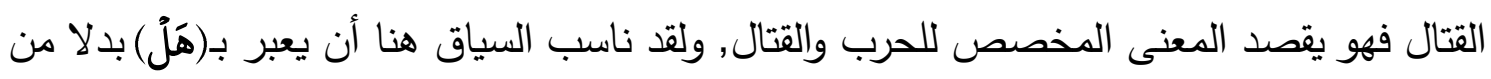
همزة الاستفهام ذلك أن هل تُبئ عن تحقيق الاستفهام وتأكيده(")، وكذلك التعبير بالفعل (كُتبَبَ)

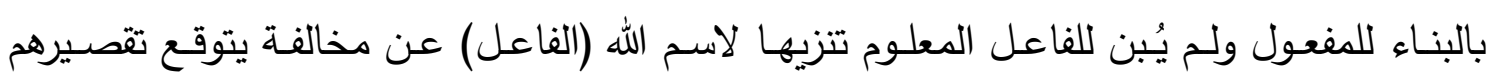

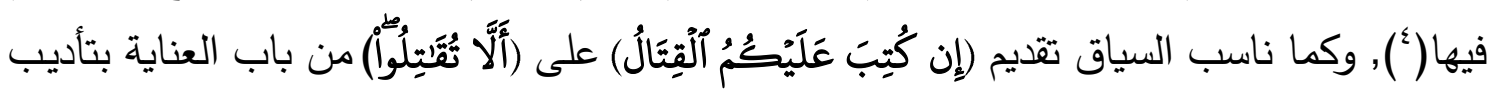

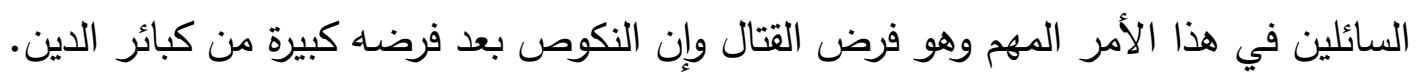

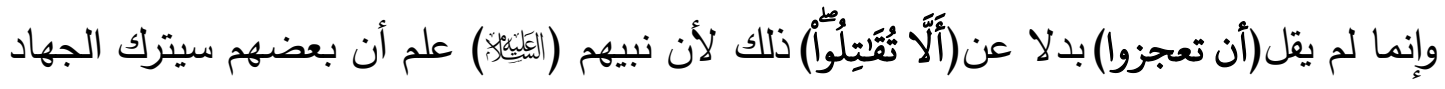

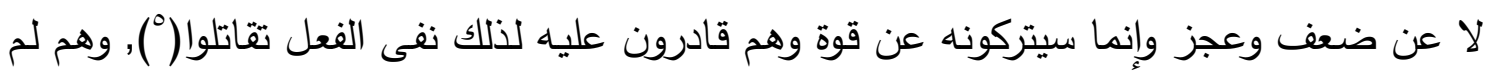

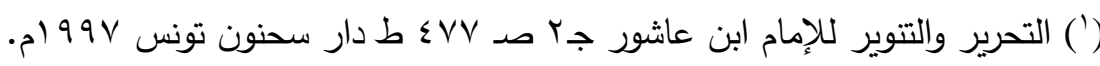

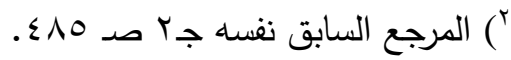

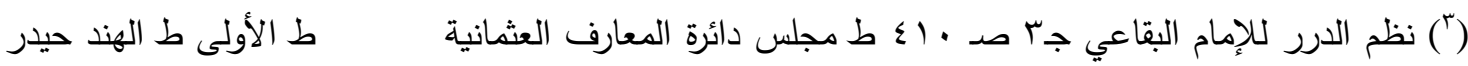

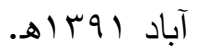

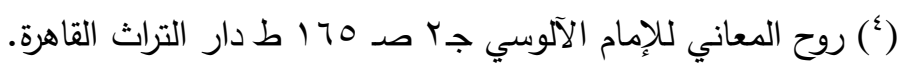

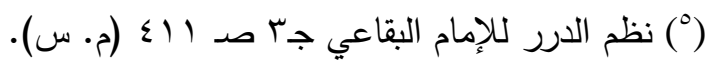




\section{حولية كلية الدعهوة الإسلامية بالقاهرة}

كهِفقه القيادة العسكرية من خلال قصة طالوت

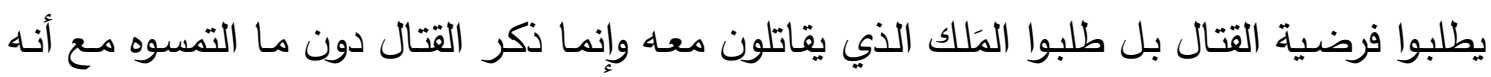
أظهر مبالغة في بيان تخلفهم عنه فإنهم إذا لم يقاتلوا عند فرضية القتال عليهم بإيجاب الله فلأن لم يقاتلوا عند عدم فرضيته أولى، وليبين لهم أن سبب تخلفهح عن القتال ليس هو عدم وجود الملك لكان

ولكن العلة في نفوسهج(').

وكما ناسب السياق دخول الواو على (وَمَا لَّاً) لتدل على ربط الكلام بما قبله تأكيدا لرغبتهم في تعيين ملك يدبر لهم أمور القتال لأنهم ينكرون كل خاطر يخطر في نفوسهم من التثبيط عن القتال,

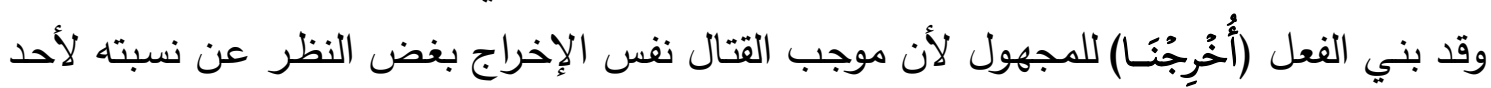
معين(r)، وإنما ذكروا الأبناء لأنهم الذين وقع عليهم السبي، أو لأنهم بمكان فوق سائر الترابة لمزيد

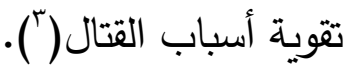

ثم بدأت الآيات في تفصيل ما جرى بينهم وبين نبيهم من الأقوال والأفعال، وقد أخبرهم نبيهم أن

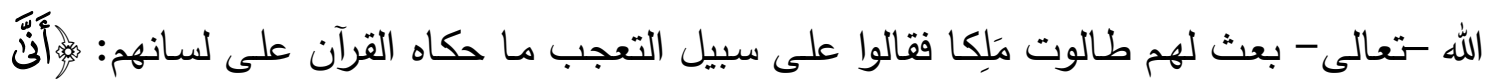

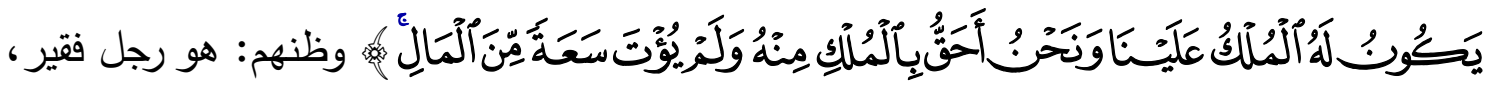

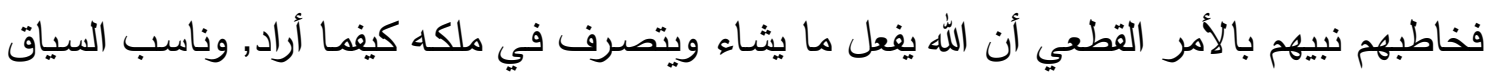

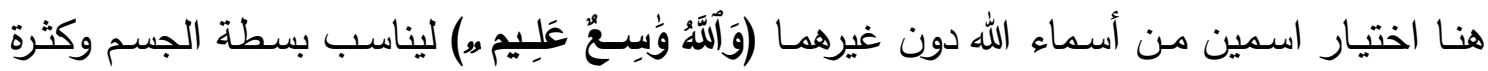

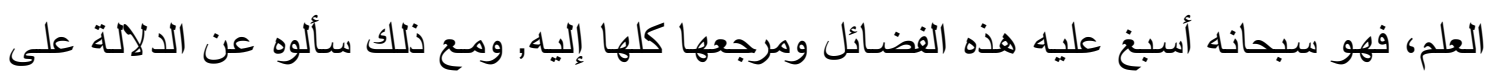

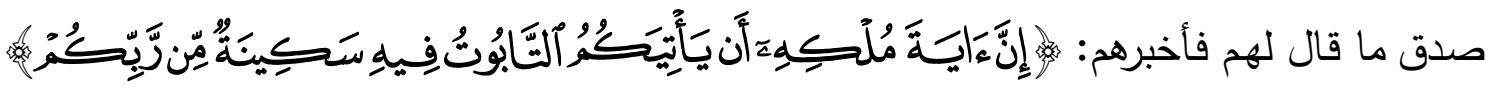

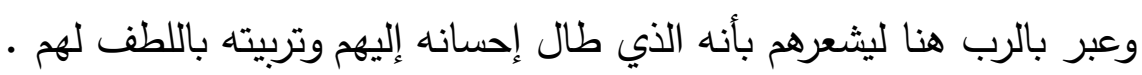

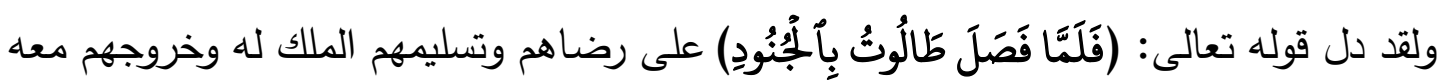

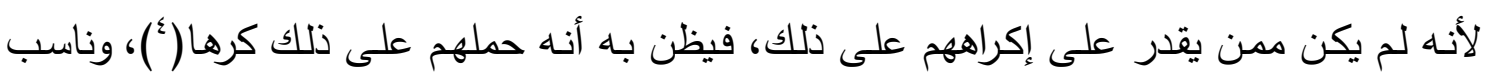

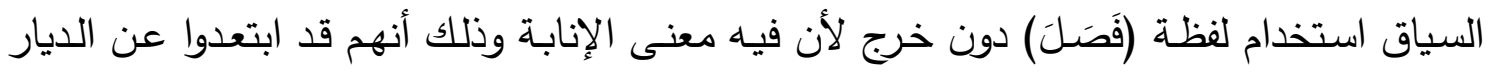

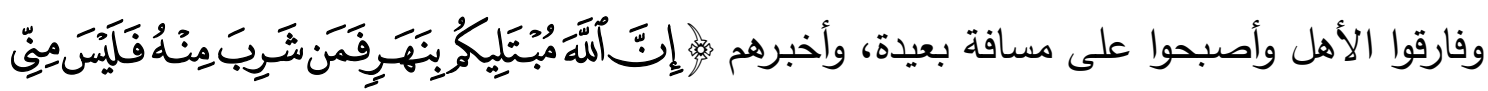

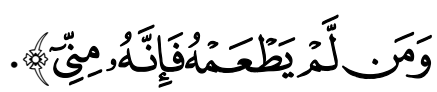

$$
\begin{aligned}
& \text { (') روح المعاني للإمام الآلوسي جr صد } 170 \text { (م. س). }
\end{aligned}
$$

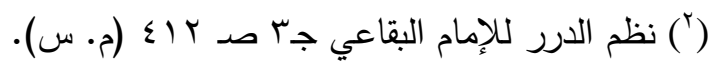

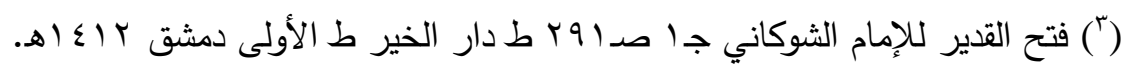

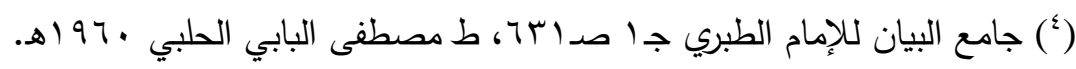




\section{حولية كلية الدعوة الإسلاهية بالقاهرة}

كهيعفه القيادة العسكرية من خلال قصة طالوت

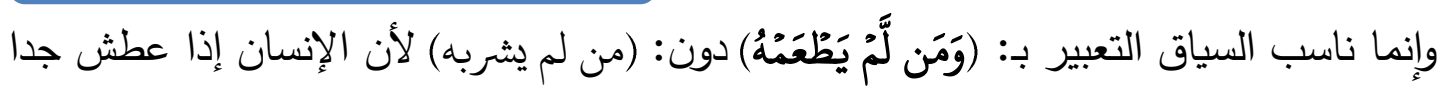

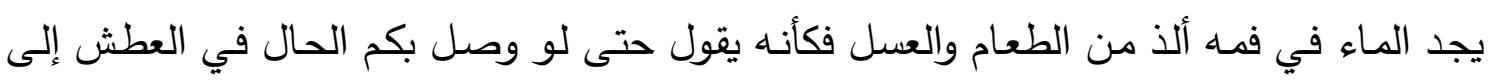
ذلك فإنه يجب الاحتراز منه، وأن من أدخل الماء إلى لسانه فقط وتمضمض به ثم أخرجه يصدق عليه أنه طعمـه وذاقه ولا يقال شربه، فلو قال القائد طالوت: (ومن لم يشربه) لظن البعض جواز الطعم خصوصا وأن الممنوع من شرب الماء إذا تمضمض به وجد نوع خفة وراحة( ').

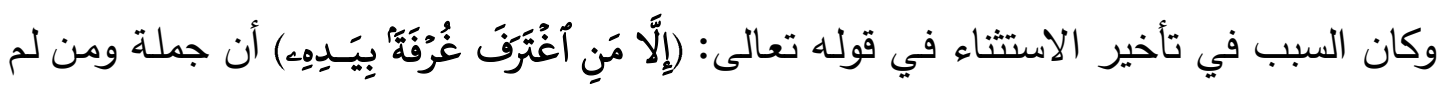
يطعمه إنما هي تتمة للجملة الأولى في النهي عن الثرب، وليعلم السامعون أن المغترف غرفة بيده هو كمن لم يشرب شيئا، وأنه ليس دون من لم يشرب في الولاء والقرب وليس هو قسماً ثالثاً ()'. ولما برزوا لجالوت وجنوده) قال الذين لايهم علم ويقين (كم من فئة قليلة غلبت فئة كثيرة)، وناسب السياق لفظة (غَلَبت .) دون (أطاقت) حسبما وقع في كلام أصحابهم الذين (قالوا لا طاقة) لنـا مبالغـة في تشـيعهم وتسلية لقلوبهم(")، وقد دعوا الله أن يصـب عليهم الصـبر حتى يكون مستعليا عليهم، ويكون الصبر كالصندوق وهم في داخله وقد امتلئوا بـه وأحاط بهم من كل جانب،

وتثبيت الأقدام كناية عن تقوية القلوب وتثجيعها حتى لا تفر وتتهزم(").

وجاء بوصف (ألْكَفِرِينَ) بدلا من الضمير العائد إلى جالوت وجنوده للإشعار بعلية النصر عليهم وخذلان أعدائهم بصفة الكفر التي هم عليها( (), فاستجاب لهم ربهم فأفرغ عليه صبره وثبت

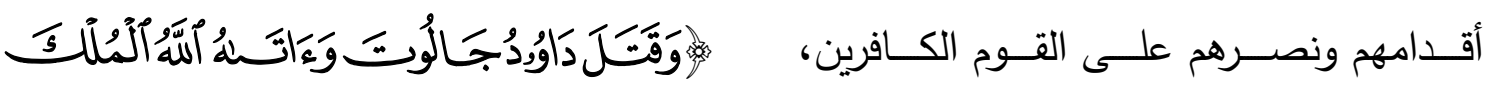

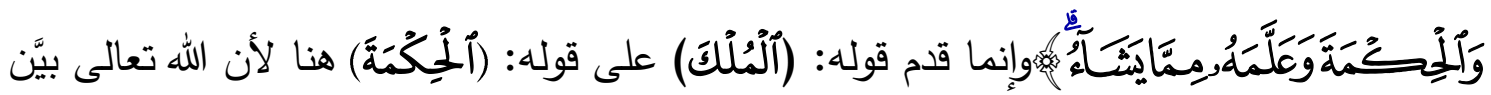
كيف ترقى داود (الئلنِّهُ) إلى المراتب العالية، فكان ما كان أكثر تأخرا من الذكر كان أعلى حالا وأعظم رتبة.

ولما بيَّن سبحانه أن الفساد الواقع بجالوت وجنوده زال بما كان من طالوت وجنوده،بيَّن عقيب ذلك جملة تشتمل على أن الله يدفع الناس بعضهم ببعض لكي لا تفسد الأرض، ولما كانت الآية

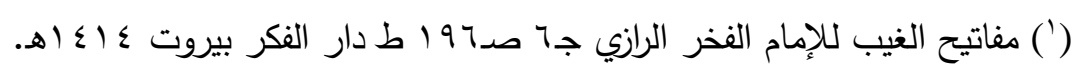

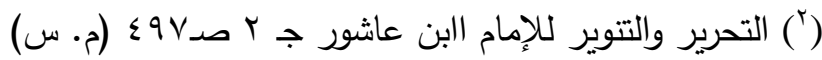

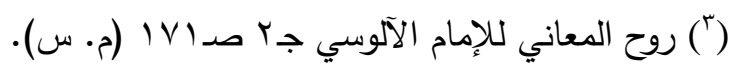

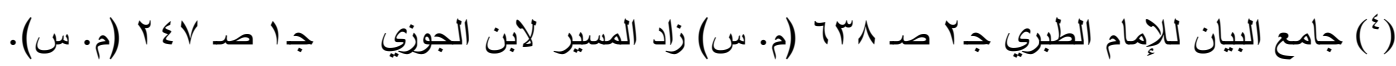

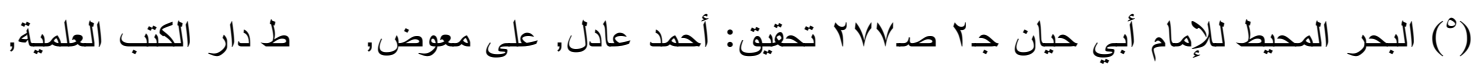

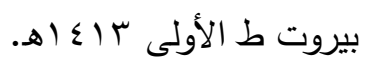




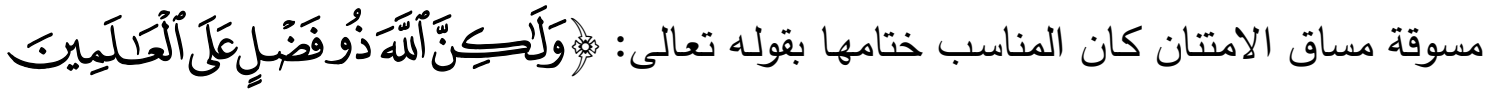
هأم لأن هذه المنة لا تختص بأحد فهو إنعام يعم الناس كلهم. والخلاصــة: إننـا نلحظ مدـا سـبق الدقـة التامسة في دقـة الألفـاظ وحسـن ورودهـا ووضـعها في مواضعها لإصابة المعنى، وقد يدركها القارئ وقد لا يدركها إلا بالتعدق في اللغة، فعبارة القرآن هي التي كست معـاني تلك القصــة حُلـة الإعجـاز ، وأوردتها إلى الأسـماع في تلك الحـلاوة, والتــاغم السياقي, فسبحان مَن هذا كلامه.

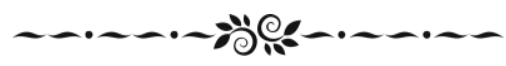




\section{المبحث الثاني}

( العطاءات الإلهية في شخصية القائد الألهُهَمر)

ويشتمل على ثلاثة مطالب:

• المطلب الأول: الاصطفاء الإههى

• المطلب الثانى: البسطة في الجسم

• المطلب الثالث: البسطة في العلم 


\section{حولية كلية الدعهوة الإسلاهية بالقاهرة}

كعيقه القيادة العسكرية من خلال قصة طالوت

إنه في ظل فترات عصيبة عاشها بنو إسرائيل في حالة مُزرية من الذل والانكسار , حيث سلَّط

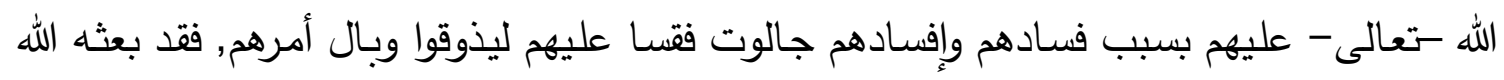

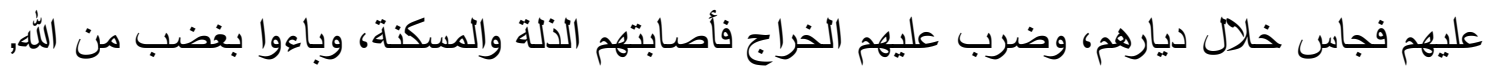

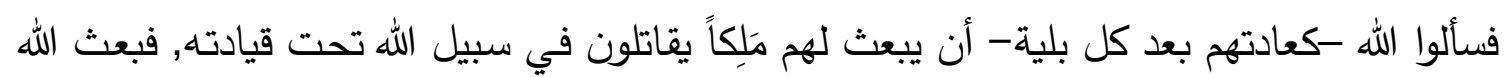

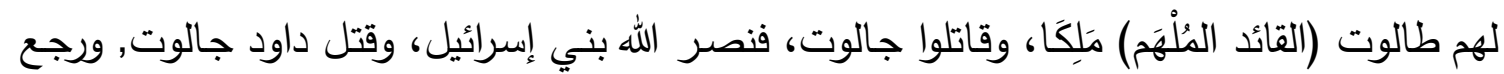

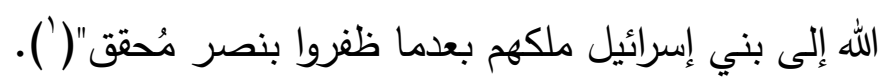
وهذا ما اختاره الإمام الأكبر المرحوم الدكتور محمد سيد طنطاوي (بكالمنَّ) ذاكرا أن هذا ما يراه المحقّون من أهل التفسير، وقد شفع اختياره هذا بعدة أمور , أههها:

أولاً: أن هذه القصة (قصة طالوت) ذكرت في القرآن الكريم كمثال لحالة الذلة والهوان والهزيمة

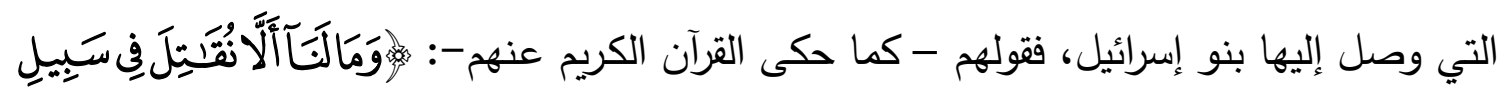

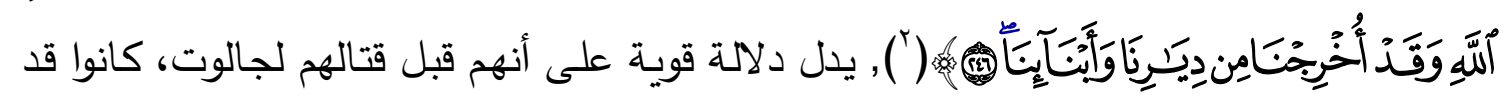

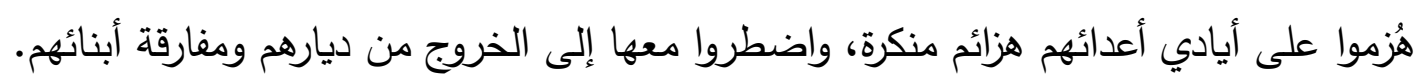

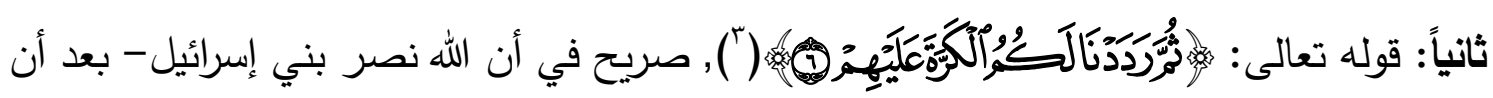

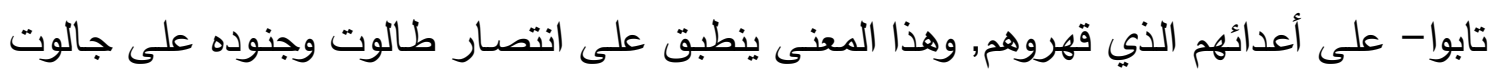
وجنوده. وكان هذا النصر نعمة كبرى بعد أن أُخرجوا من ديارهم وأبنائهج.

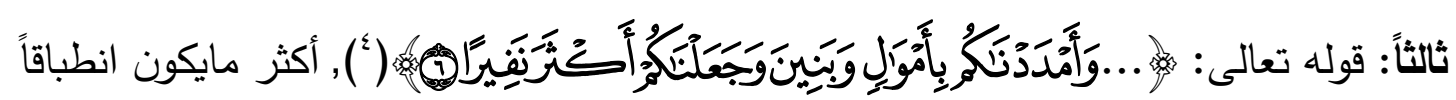

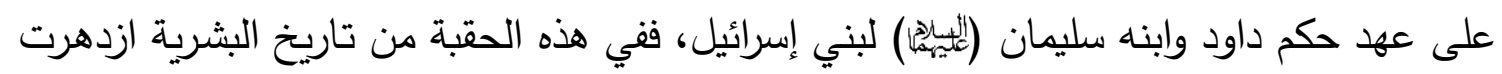

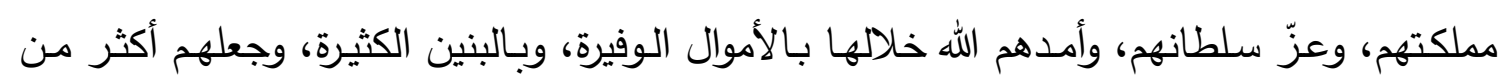

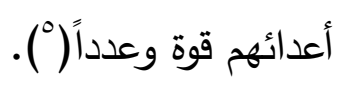

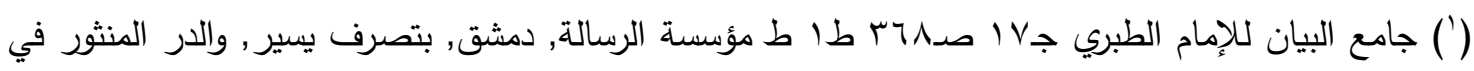

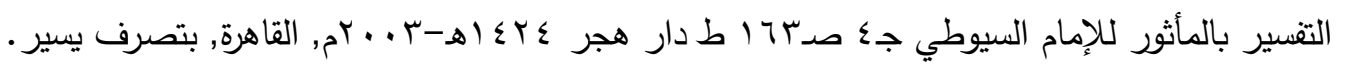
(') سورة البقرة من الآية بك بك.

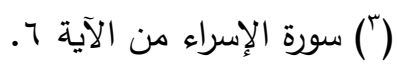
(") سورة الإنراء من الآية الكصدر السابق.

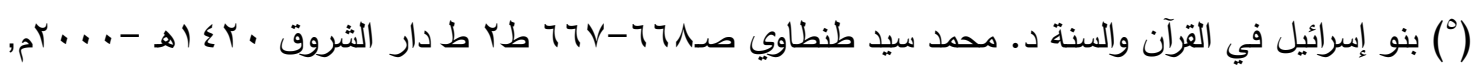




\section{حولية كلية الدعوة الإسلاهية بالقاهرة}

كهِفقه القيادة العسكرية من خلال قصة طالوت

والحقيقة: لقد نجـح القائد المُلْهَهم (طالوت) في تنظيم الجيش وإعداده وإعادة هيكلته على نُظم حديثة, ونجح في تغيير مسار الهزيمة إلى نصر ورفعة, وهو شان القادة العظام, وذلك بما وهبه الله -تعالى - من عطاءات وقُدْرات عقلية وجسمية ساعدته على ذلك, ننجزها في الآتي:

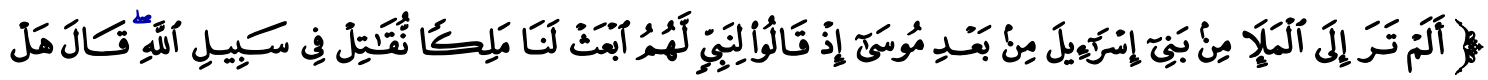

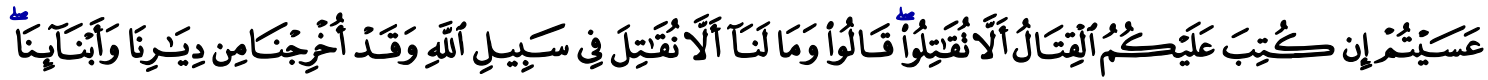

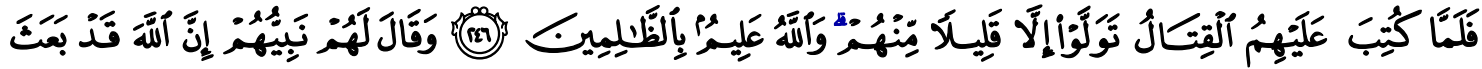

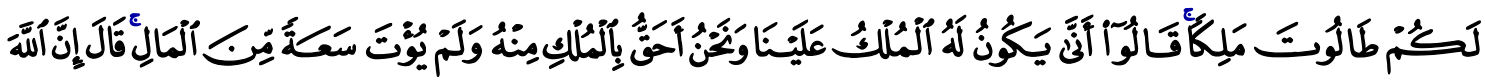

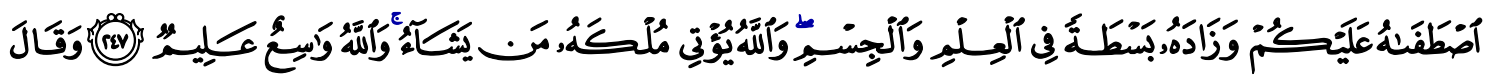

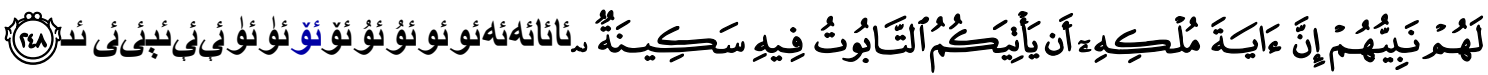

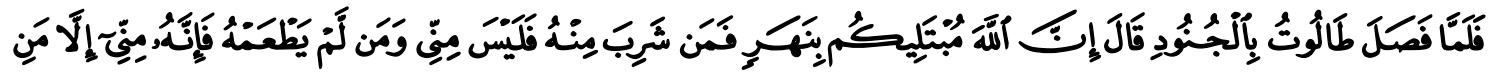

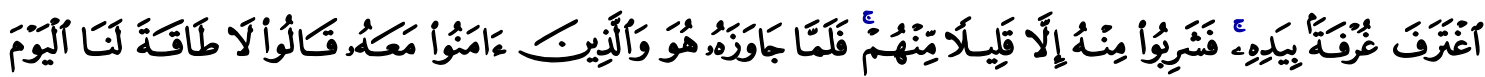

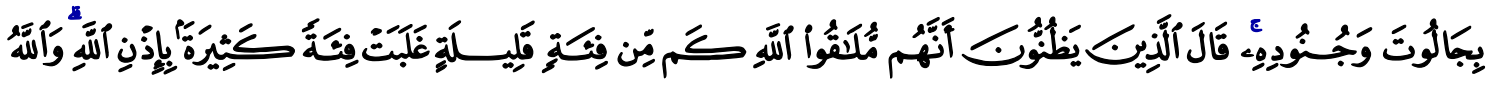

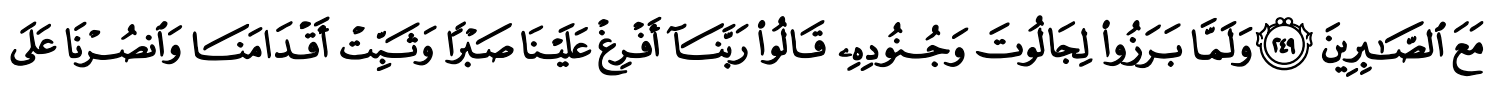

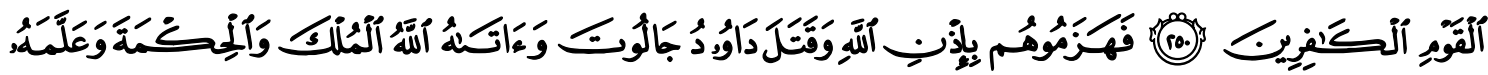

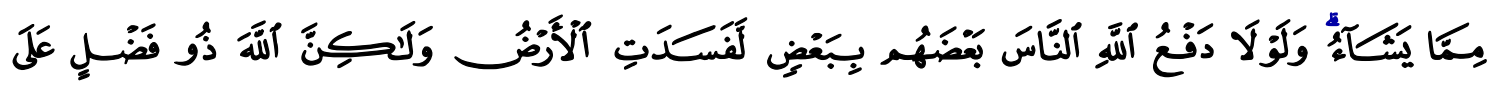

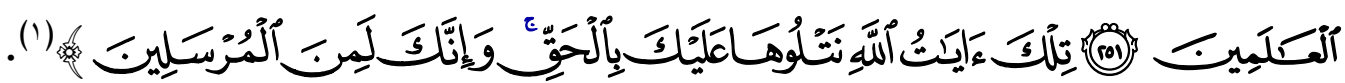
ولعلنا -من خلال النص القرآني السابق- نستطيع أن نستخلص العطاءات الإلهية أو أسباب

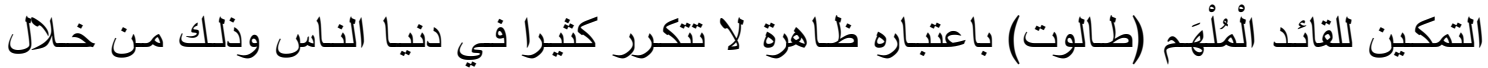

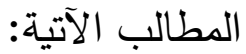

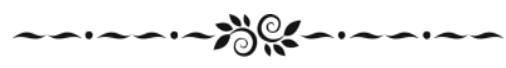




\section{المطاب الأول \\ الاصطفاء الإهي}

إن الله - تعالى - اصطفى طالوت واجتباه على بني إسرائيل, والاصطفاء يعني: الاختيار ،

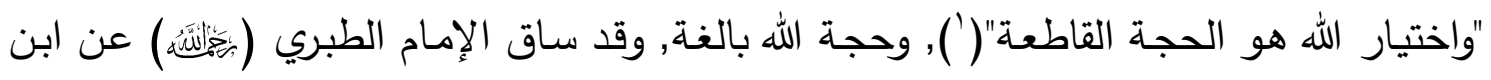

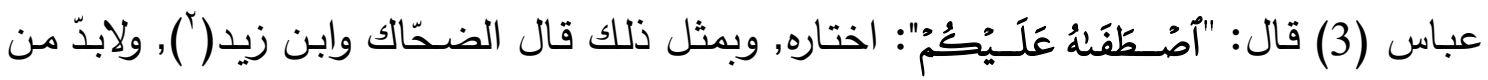

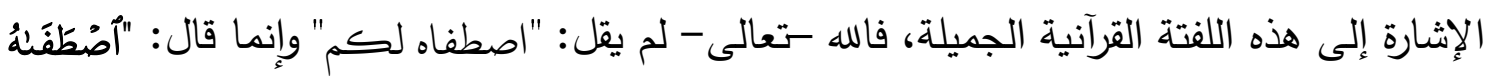

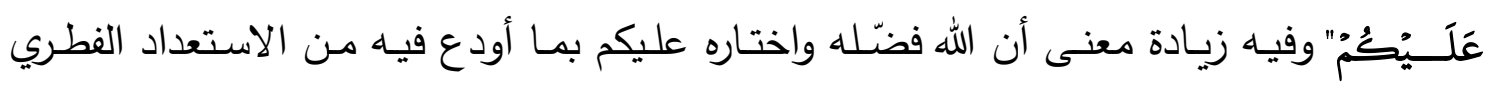
للمُّلك ("), وذلك فضل الله يؤتيه مَن يشاء, وكذلك كاد الله له. إن بني إسرائيل لم يفقهوا, وإن شئت فقل: إنهم قوم لم يُهدوا إلى معنى اصطفاء الله -تعالى -

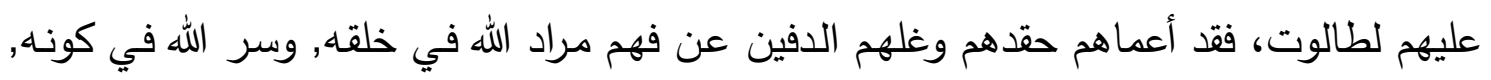

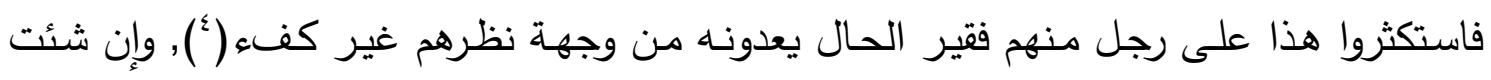

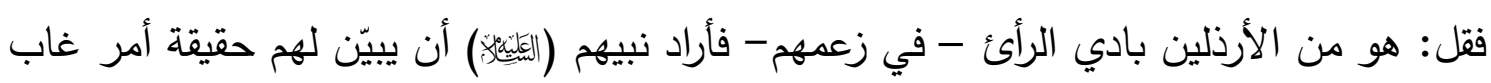

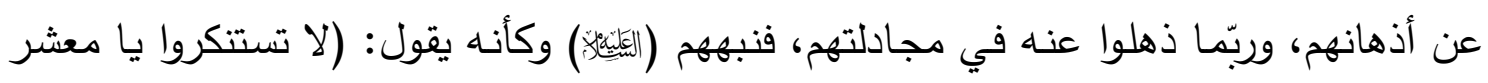

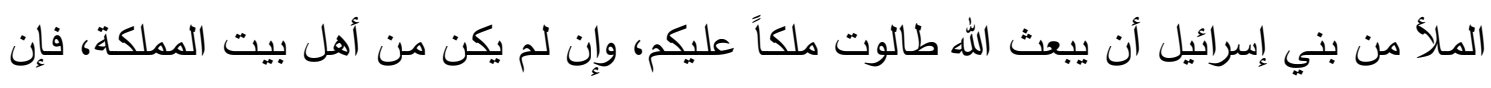

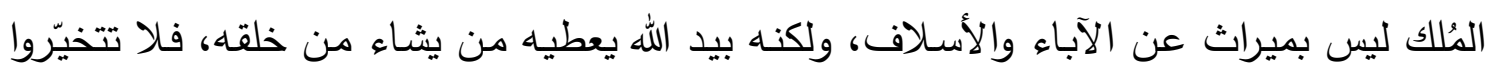

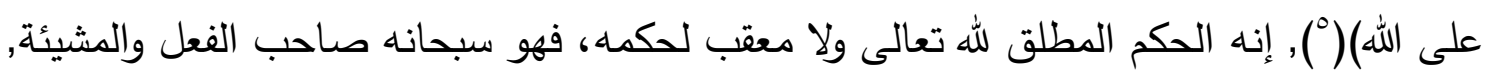

(') فتح القدير الجامع بين فني الرواية والدراية من علم التفسير للإمام الثوكاني جا صد اج طا ط دار الخير، دمثق.

(') جامع البيان للإمام الطبري, تحقيق: محمود, أحمد شاكر جه صد آب طا ط مؤسسة الرسالة, دمثق.

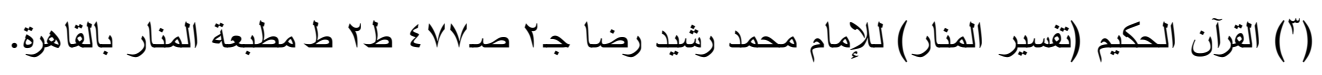

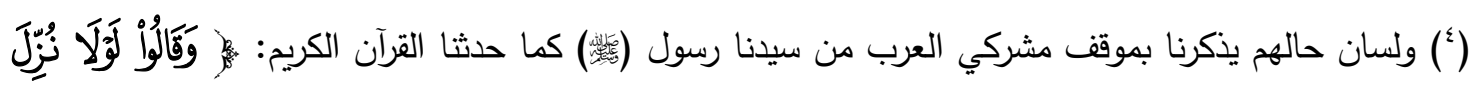

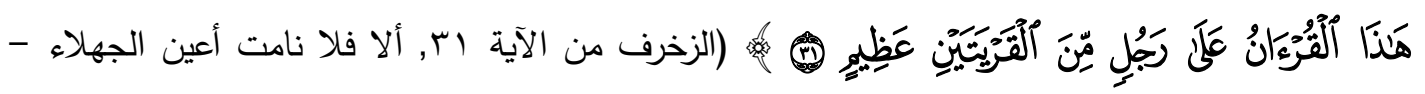

$$
\text { () جهلاء الفكر والبصيرة-. }
$$


كع فقه القيادة العسكرية من خلال قصة طالوت

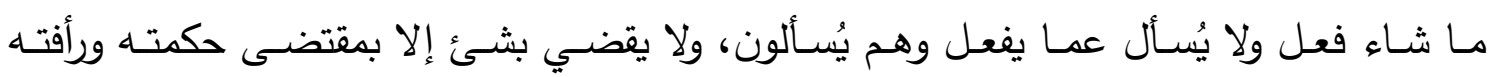
بخلقه(')؛ فإذا كان الله هو المالك فله أن يُمَكِّن مَنْ شاء من التصرف في ملكه بإذنها(').

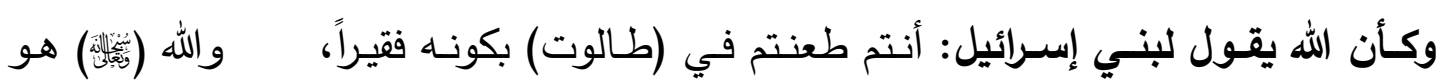
الواسع، فإذا كان المُلْك لا يتمشى إلا بالمال، فالله -تعالى - يفتح عليه باب الرزق والسعة في

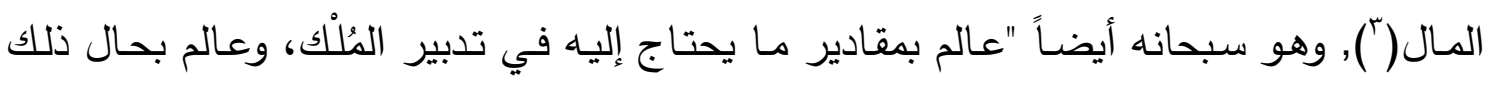
الملك في الحاضـر والمستقبل، فيختار لعلمه بجميع العواقب مـا هو مصـلحته في قيامـه بأمر المُلْك"() ), وبذلك تنقطع الأفهام السقيمة لأصحاب الفكر غير السوي, وتذل للواحد الأحد الذي أحاط بكل شيء علماً، فما اختاره -جلَّ شأنه- هو المختار لا مُحال، وليس لأحد معه خِيَرَة في الأرض ولا في السماء، يفعل ما يشاء ويختار , بل يفعل مالا تدركه العقول ولا تُحيطه، ولا تحتمل وصفه الألباب والفهوم, ولا تعيه القلوب.

لقد كان الدرس قاسيا حين خاب ظنهم, وأتت القضـاء بمـا لا يشتهون, وأتاهم القدر بما لا يريدون, فكم تمنوا واحدا من أصحاب الجاه والسلطان سليل بيت المملكة, ولو أُجيبوا لما طلبوا لجروا ذيل الهزيمـة والانكسـار الذين لازمهما -كعادتهم - لعقود طويلـة, لكنها إرادة الله ومشيئته الباقية أبد الدهر مـا قام الزمان في دنيا الناس, ليبقى الكون دائما قائما لله بحجتة البالغة, فهو وحده عالم بمصلحة عباده يفعل ما يشاء ويختار .

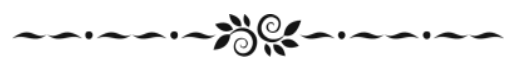

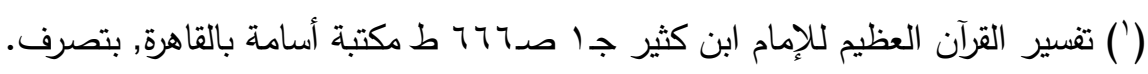

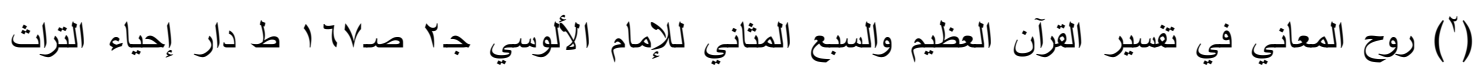

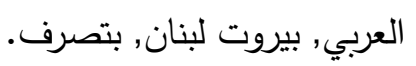

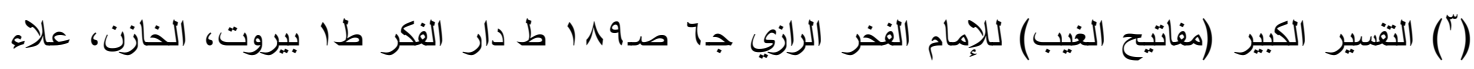

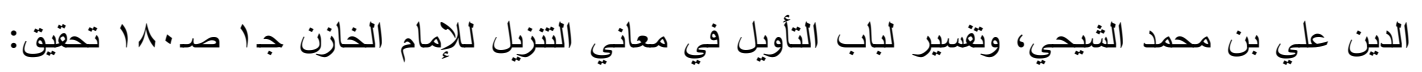

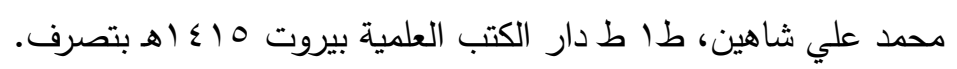

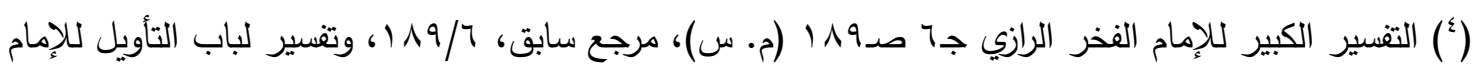

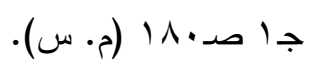




\section{الاطباب الثاني

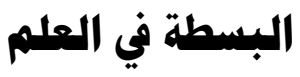

عن القائد المُلهَم يقول ابن عباس (3): (كان طالوت يومئذٍ أعلم رجل في بني إسرائيل)('),

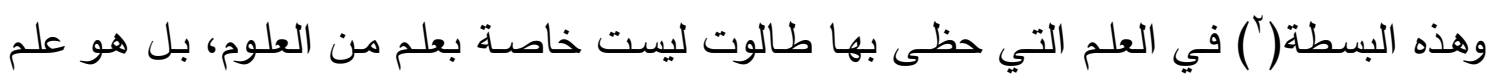
مطلق(")؛ وذلكم أن القرآن الكريم عندما أشار إلى أنه أوتي بسطة في العلم أشعرنا ذلك بأنه لم لم يختص بعلم واحد دون سائر العلوم، بل ينطبق ذلك على العلم الديني والدنيوي، إذ إن مهمدة إنها

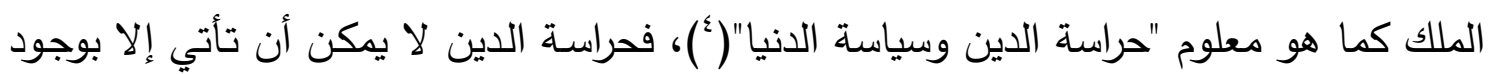

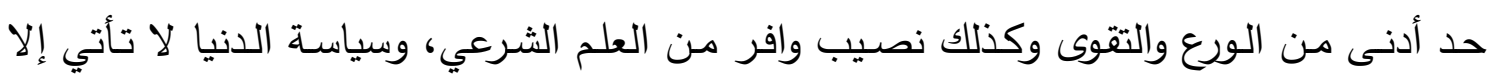
بوجود الخبرة الميدانية والثقافة العسكرية والحربية، وهو أهم جوانب المؤهلات القياديـة في أي ولي شخصية ريادية. ولأهمية العلم للملك والقيادة قدّمها الله في الآيـة على الجسم, وكذا قالوا: "الفضـائل النفسانية

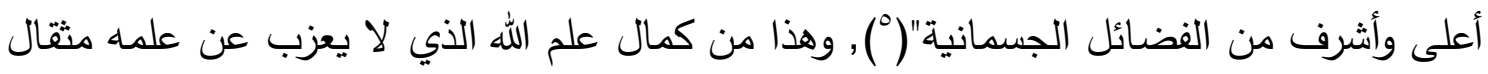

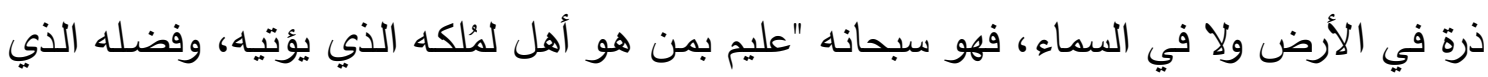

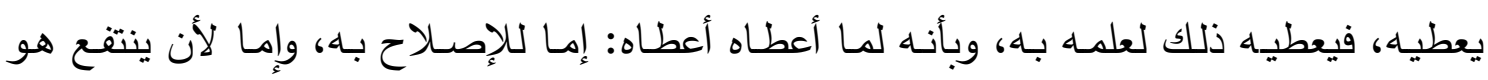

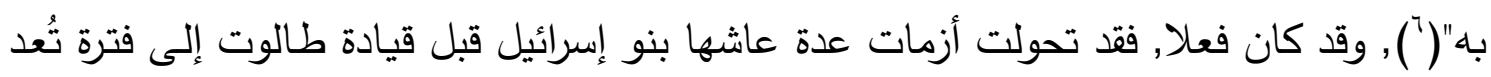

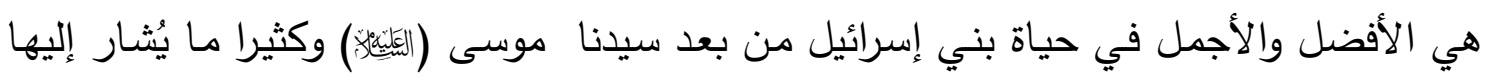
بالبنان, لما تحقق فيها من نصر وعزة نتيجة فقه القيادة الرشيد والحكيم.

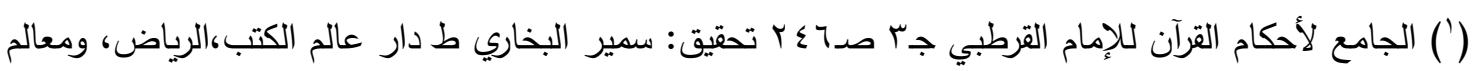

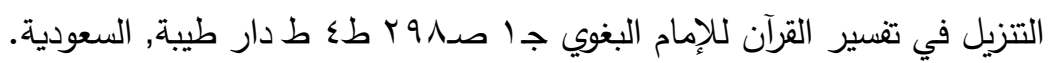

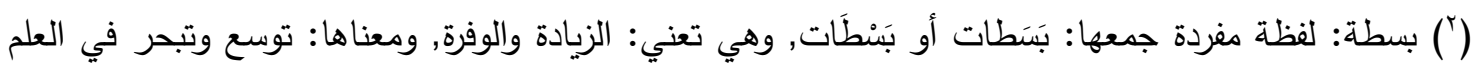

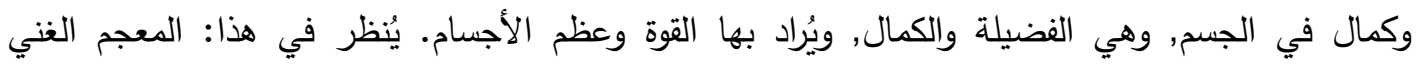

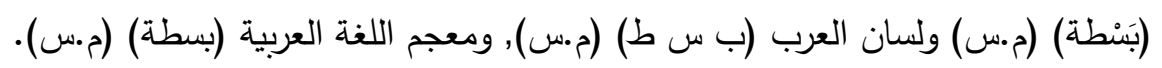

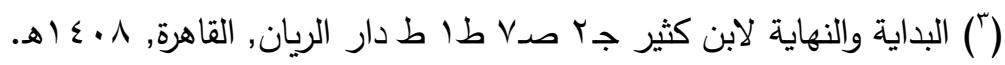

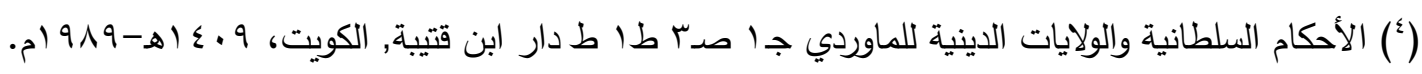

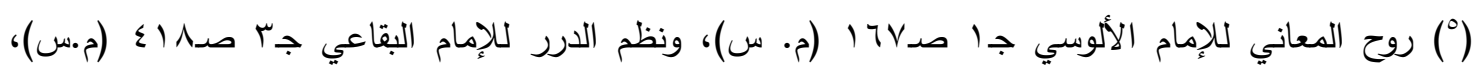

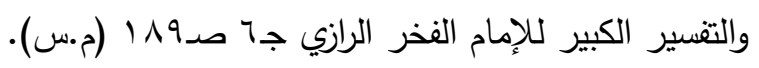

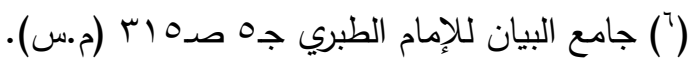


كعبقه القيادة العسكرية من خلال قصة طالوت

لقد كان من شأن العلم توليد الحكمة عند القائد المُلهَمَ, وهي مطلب هام في شخصية كل قائد,

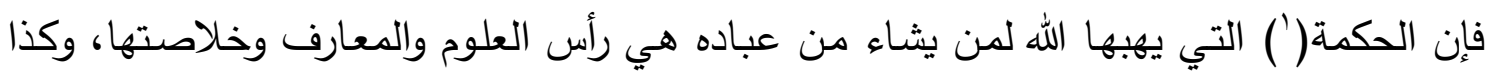

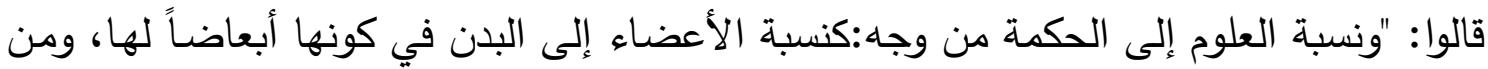

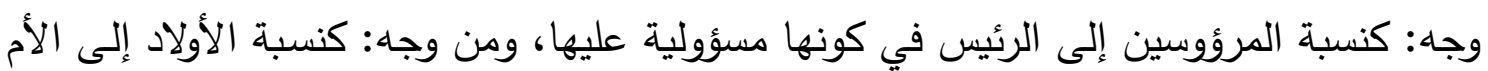
في كونها مولّدة لها، وهي في معارف الثروع: اسم للعلوم العقلية المدركة بالعقل. وكما يقول الراغب الأصفاني (كائ)): "ولايبلغ الحكمة إلا أحد رجلين: إمـا مهذب في فهمها،

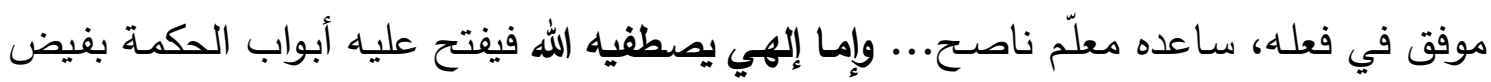

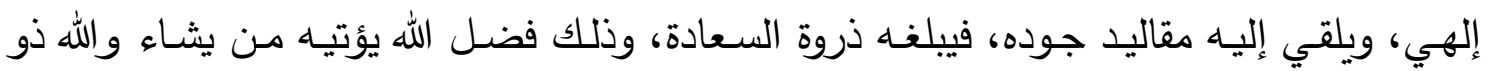

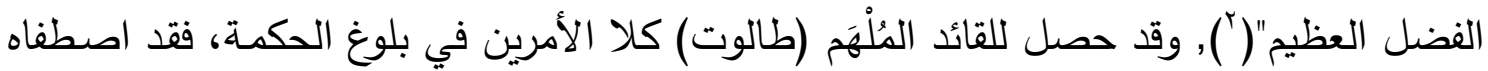
ربّه بذلك.

فالحكمة من المعاني الجامعة التي يندرج تحتها أمور كثيرة, أهمها: سداد الرأي، والدقة والعمق

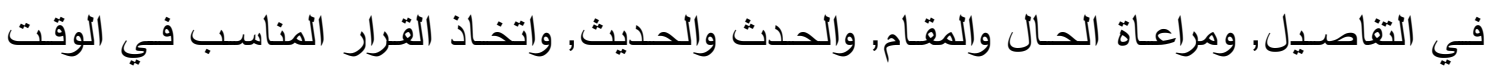

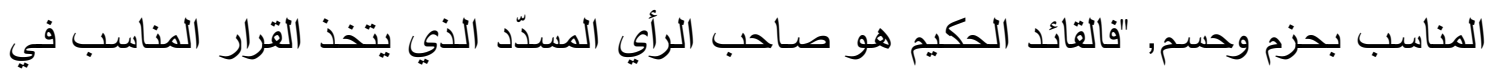

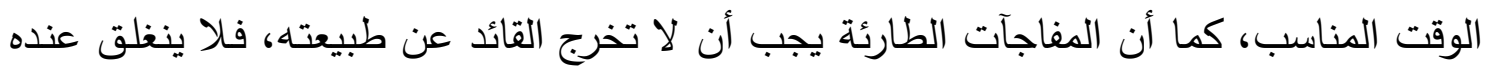

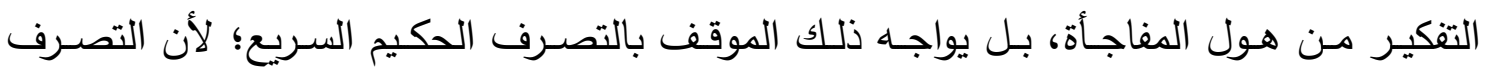

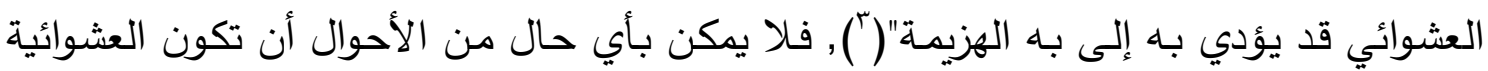

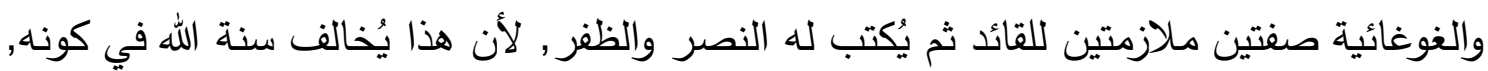

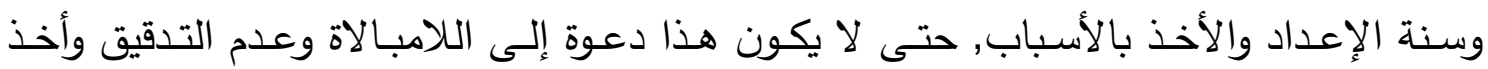

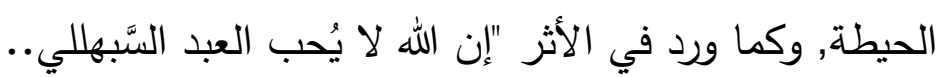

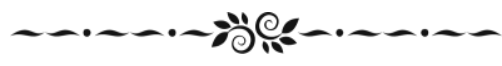

(') (') السابق نفسه, الصفحة نفسها.

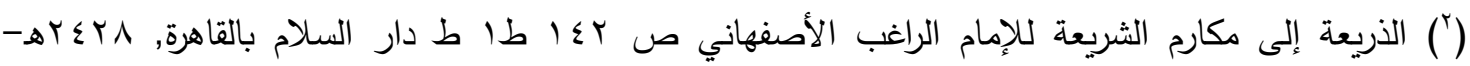
. ז. . V

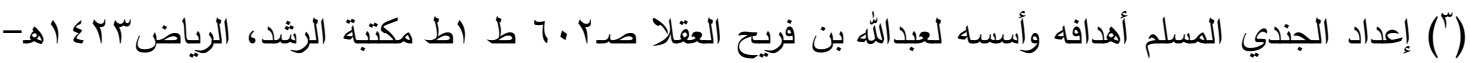

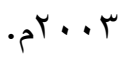




\section{الإطلب الثالث}

\section{البسطة في البسم}

إن المعنى اللغوي للبسطة سواء في العلم أو الجسم يوحي بالسعة والانتشـار، فالبسطة هي:

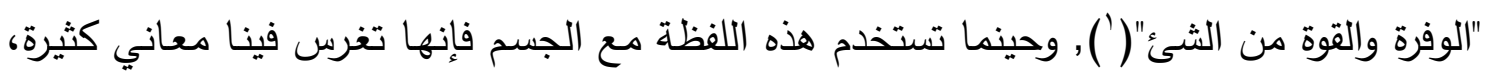

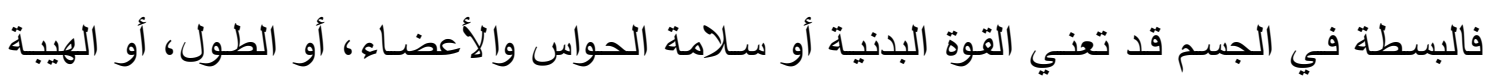
والجمال، أو غير ذلك من المعاني المتعدّدة من جملة بسطة الجسم. ويجدر بنا هنا أن نميز بين لفظة (الجسم) ولفظة (الجسد) فهما كلمتان متقاربتان في الحروف

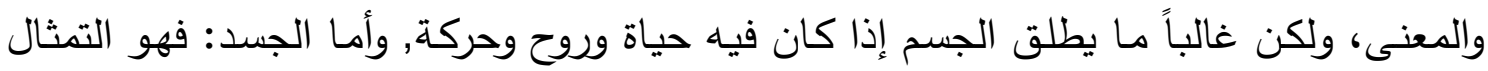

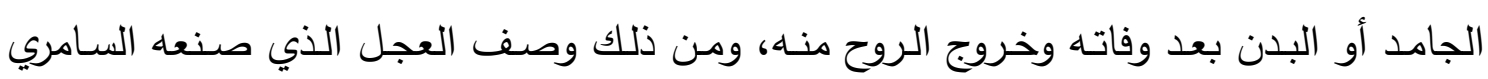

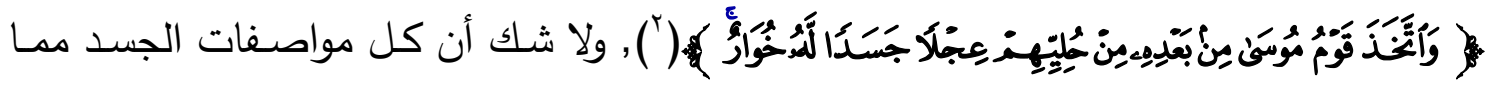

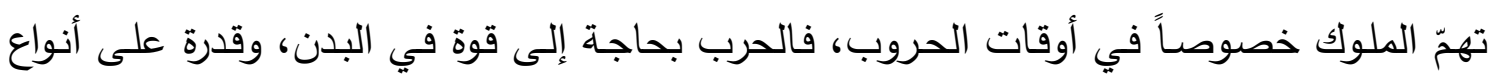

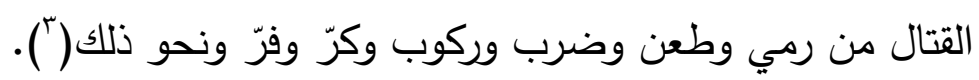

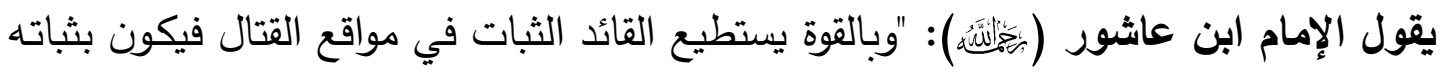

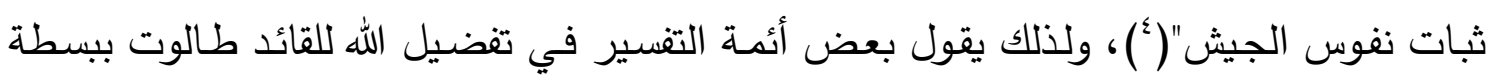

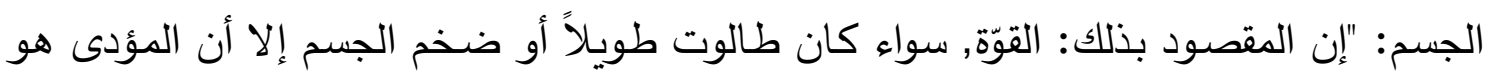

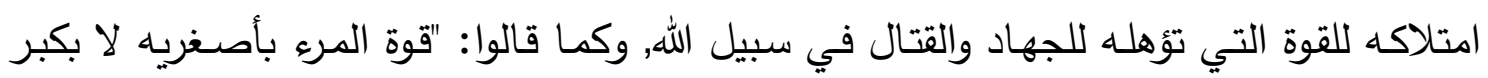

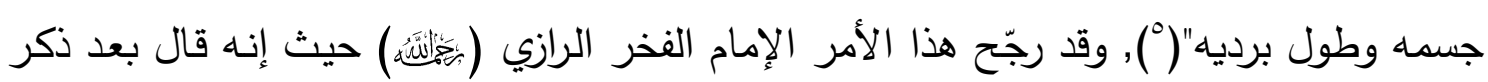

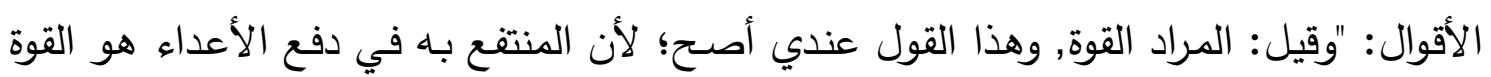
والثدة, لا الطول والجمال"(").

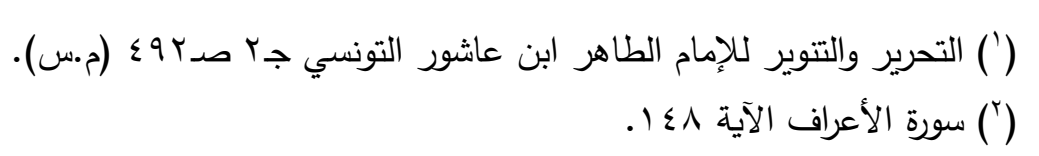
(") حسن السلوك الحافظ دولة الملوك لابن الموصلي صدوه تحيق: فؤاد عبد الهنعم طا ط دار الوطن

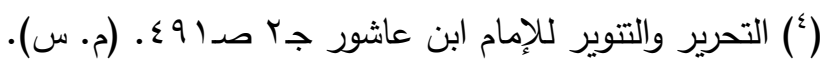

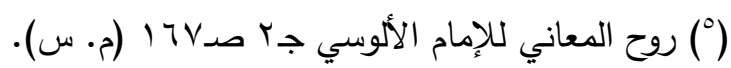

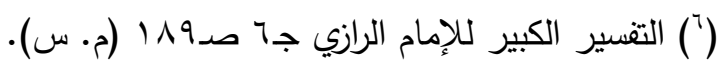




\section{هولية كلية الدعوة الإسلاهية بالقاهرة}

كعه فقه القيادة العسكرية من خلال قصة طالوت

ولقد بلغ القائد الْمُلْهَمَ (طالوت) غاية القوة في جميع جوانبها, والتي تختزل عدداً من الصفات المتنوّعة, وهي بمجموعها تعطي شخصية القائد طالوت قوة فوق قوته, ومن أهمها: الشجاعة والإقـدام, والفصـاحة والبيـان, الذكاء والكِياسـة, الاستقلالية والثبات, وقد ذهـب الإمـام القرطبي

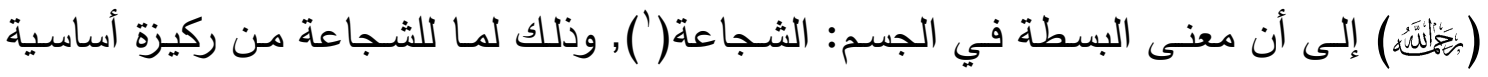
ورئيسة في الثخصية القيادية الريادية وهي بمفهوم فقه القيادة تُمثل الرصسانة والرزانـة والثبات, ولقد كان الصحابة كرضوان الله عليهم- يلوذون بسيدنا النبي (管) إذا حمى الوطيس, وقد ظهر ذلك يوم حنين(r) لما رشقت هوازن خيل المسلمين بالنبال فولوا مدبرين في بادئ الأمر منهزمين,

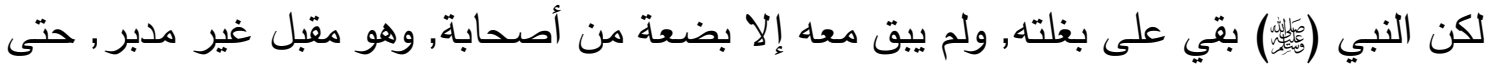

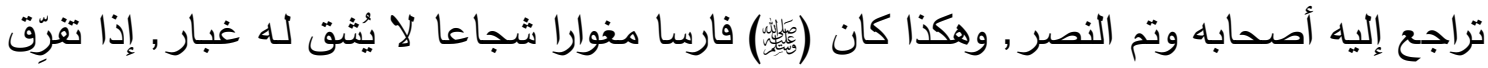
مَن حوله وقف يُنادي بأعلى صوته: أنا النبي لا كذب أنا ابن عبد المطلب. أضف إلى ذلك صفة الصبر وما تتضمنه من تحمل للمسؤلية الملقاة على كاهل القائد, والتي تُعد أمانـة في عنقه أمام الله والوطن, مما يستوجب الصبر عليها وعدم التهرب منها, وقد رأينا كيف أن القائد طالوت لم يتهرب من مسؤولية القيادة بل أخذها بحقّها, وصبر عليها حتى ظفر , ناهيك عن صفة الحزم وما يترتب عليها من القوة في اتخاذ القرار وتنفيذه مع تحمل تبعاته, أو

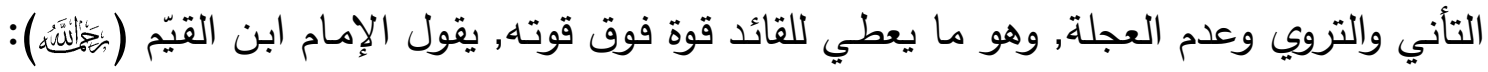
"لفظة الحَزْم تدل على القوة والاجتماع, ومنـه حزمة الحطب, فحازم الرأي هو الذي اجتمعت له شؤون رأيه, وعرف منها خير الخيرين وشرّ الثرّين, فأحجم في موضع الإحجام رأياً وعقلاً لاجُبناً

إن هذا من شأنه أن يعكس على شخصية القائد الهيبة والحلم مع الاستقلالية والثقة في النفس,

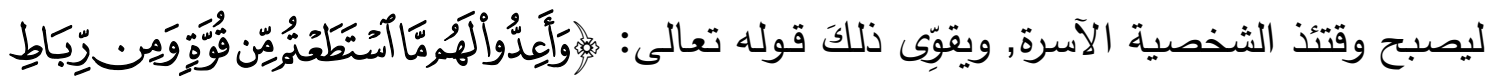

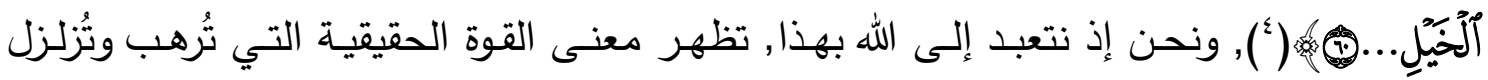

(') الجامع لأحكام القرآن للإمام القرطبي جr صت ع ب (م. س), والبحر الدحيط للإمام أبي حيان الأندلسي جr

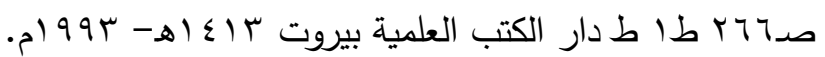
(r) هي غزوة وقعت في الثالث عشر من شهر شوال في السنة الثامنة للهجرة, وكانت بين المسلمين وقبيلتي هوازن وثقيف, في واد يُسمَّى حُنين بين مديمة مكة والطائف, وانتهت بنصر المسلمين, لمطالعتها كاملة انظر السيرة

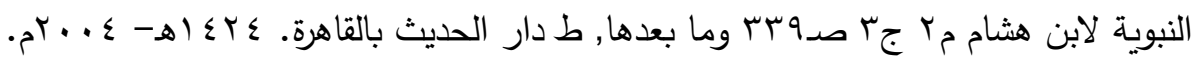

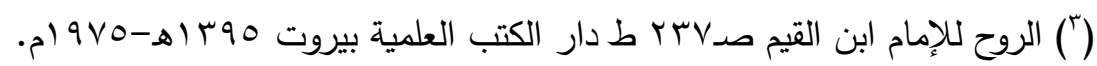

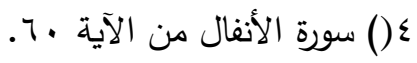


كعرفقه القيادة العسكرية من خلال قصة طالوت

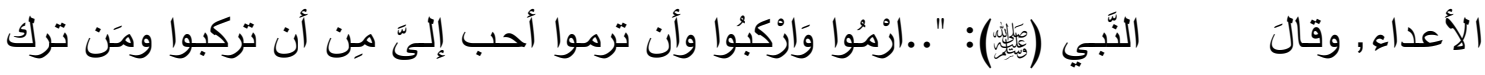

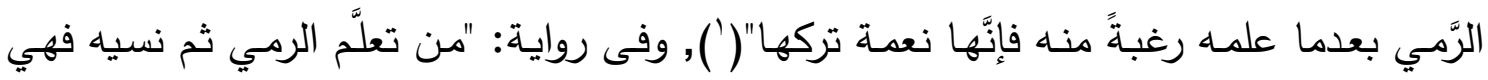

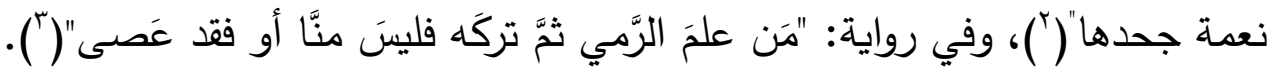

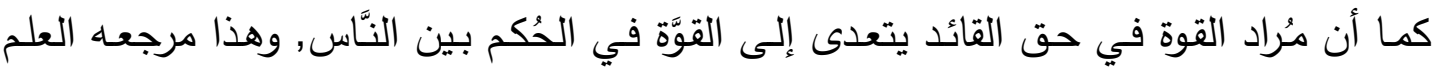
بالعدل حتى وإن تطلب هذا الإنصاف من نفسه, وإلى القدرة على تطبيق وتنفيذ الأحكام، بأمانة

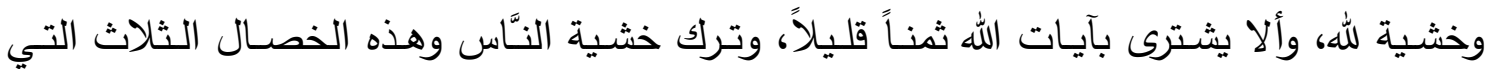

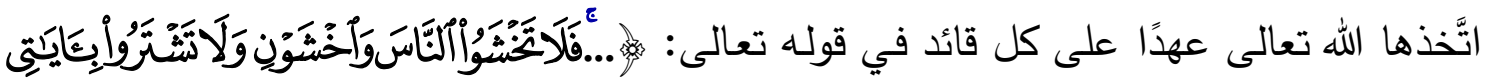

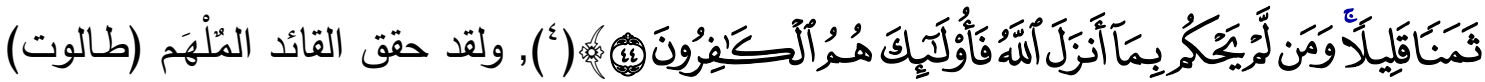
هذا فعلا فاستحق أن يكون شخصية آسرة. وتبقى الحقيقة: ثمة مبادئ تُمثل فقه القيادة العسكرية في شخصية القيائد الناجح من أهمها: غرس العقيدة الصـيحة (الثقتة في نصـر الله), صدق النيـة, الإعداد الجيد, التقوى والصـلاح, الصبر والأناة, الثجاعة عند اللقاء, الثبات إن حمي الوطيس, عدم التأثر بالإثـاعات (الحرب التاب

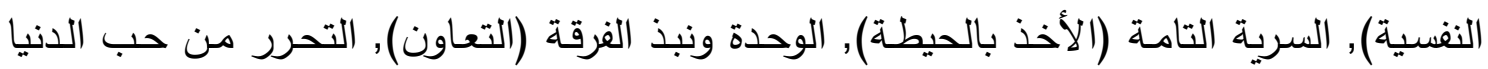

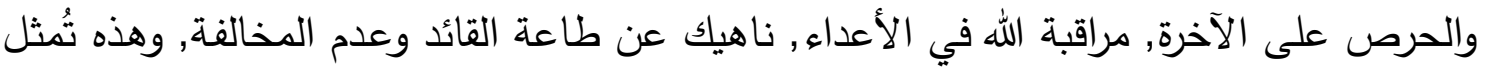
أهم المبادئ الهامة في تكوين نمط (شكل) أيّ شخصية قيادية ناجحة ذات طابع خاص وسل وسلوك

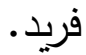

(') الترغيب والترهيب للإمام الحافظ المنذري جr صد هrr ط دار الحديث القاهرة.

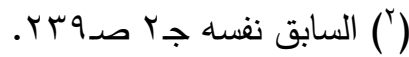

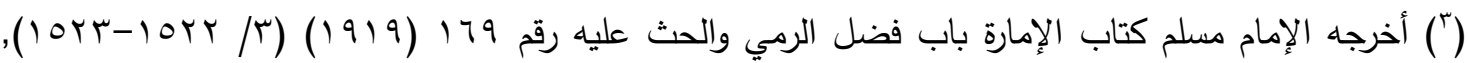




\section{المبحث الثالث}

(الأؤهلات القيادية في الشخصية الرياديةة)

ويشتمل على أربعة مطالب:

المطلب الأول: الكفاءةٌ

المطلب الثاني: احترام ضوابط الاختيارِ

المطلب الثالث: الاراسة العسكرية وفن القتاله

• المطلب الرابع: ضبط النفس 


\section{المطاب الأول}

\section{الكفاءة}

وهي في اللفــة تُطلق ويُراد بها: المساوي أو النظير أو المماثل, يُقـال: تكافـأ الثـيئان أي:

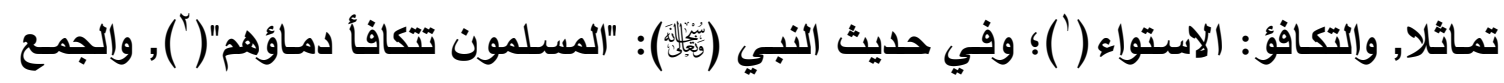

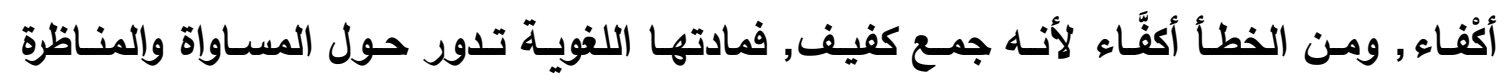
والمماثلة. وأمـا اصطلاحا فهي: "موهبة وقدرة على إنجاز العمل عند مستوى محدد، وقد تكون هذه

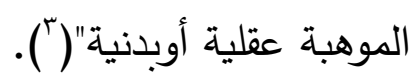

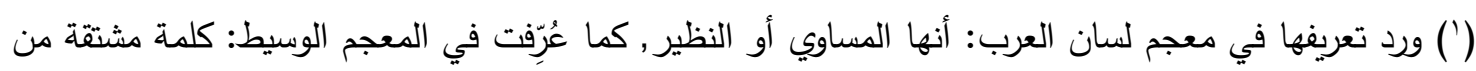

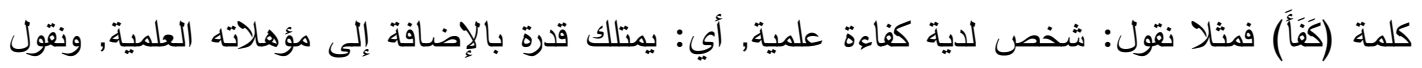

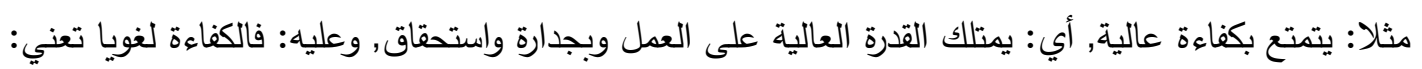

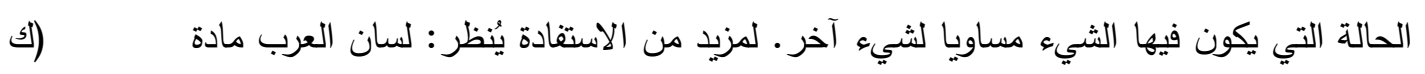

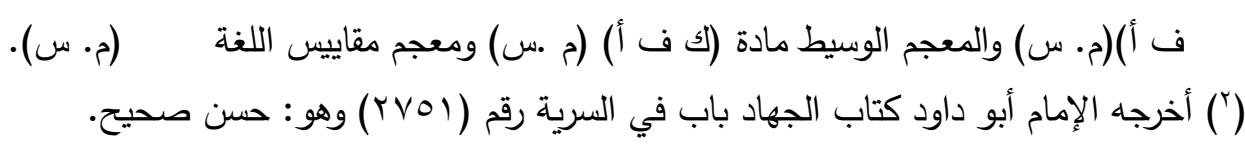

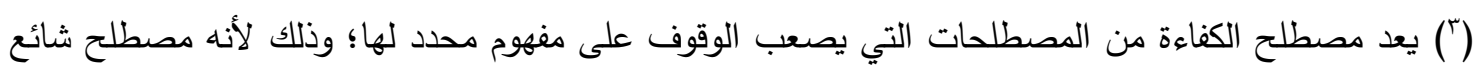

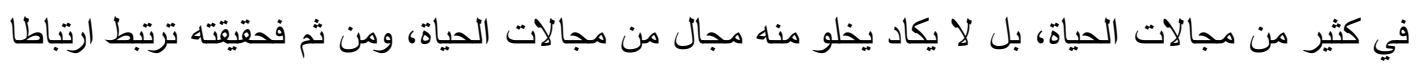

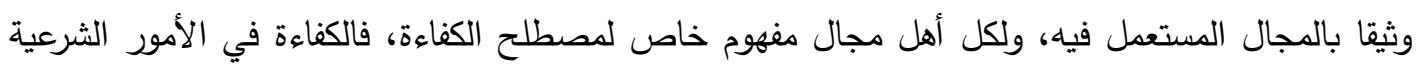

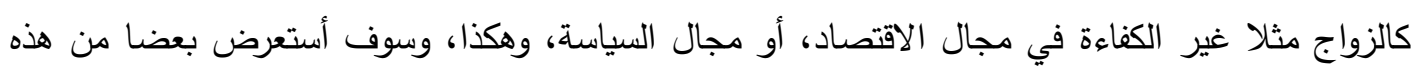

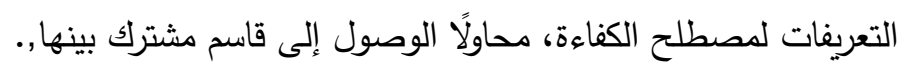
أما عن الكفاءة عند الفقهاء فقد اختلت تعاريفها بحسب اعتبارات معينة لها عندهم, فنها الدجمل ومنها الدفصل

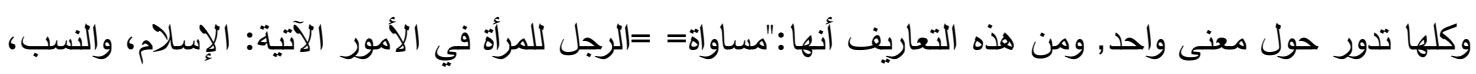

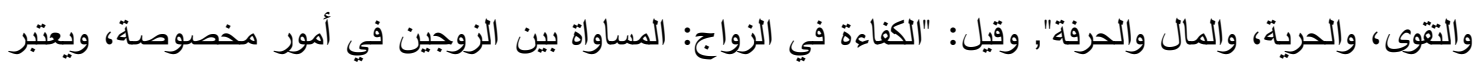

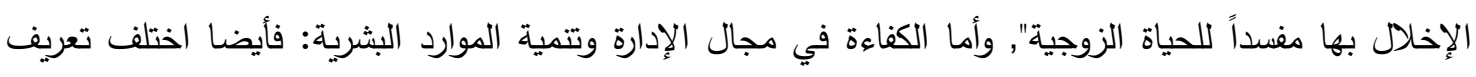

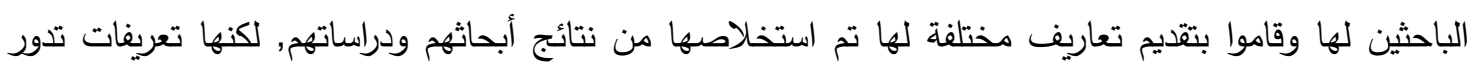

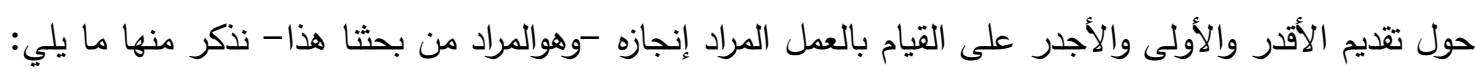

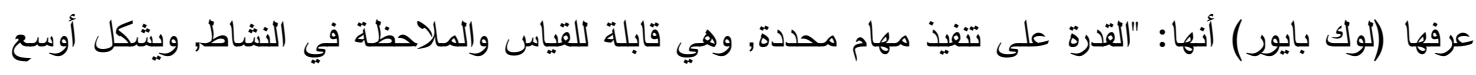

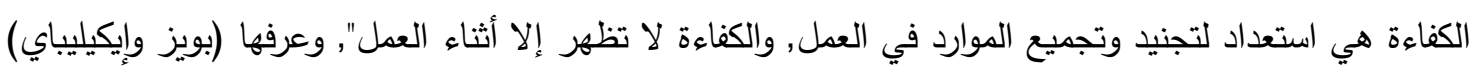

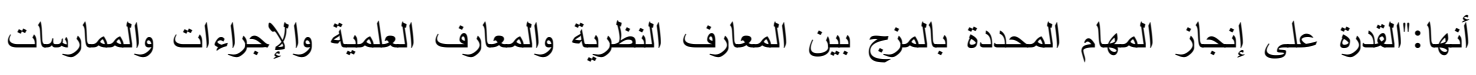




\section{كهيفه القيادة العسكرية من خلال قصة طالوت}

والكفاءة من أهم مقاييس النجاح للمؤسسـات في تحقيق أهدافها بأقل تكلفة وأقل وقت مدكن, وأجود عمل, وتصل إلى قمة الهرم حينما تجتمع الموهبتان في شخصية واحدة كما هو الحال في شخصية القائد المُلْهَم (طالوت), ومن هنا أردت أن أبدأ بها لما يترتب عليها من نجاحات قيادية

والخبرة, وعرفها (ماريو) أنها :"القدرة التي يتصرف من خلالها الفرد في وظيفة وفقًا لشروط معبئة لتحقيق الأهداف . . . . . . . .

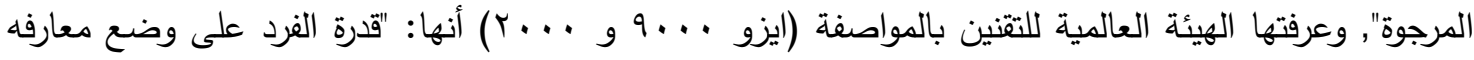
في حيز التنفيذ", وعرفتها المجموعة المهنية الفرنسية أنها: "مزيج من المعارف النظرية والمعارف العملية والخبرة الممارسة, والوضعية المهنية هي الإطار الذي يسمح بملاحظتها والاعتراف بها وعلى المؤسسة تقييمها وتطويرها", وعرفها (جان ماري بيريتي) أنها: "مجموع ثلاثة أنواع من المعارف: معارف نظرية ومعارف عملية (خبرة) ويُبْد سلوكي (الكينونة) معبأة أو قابلة للتعبأة يستخدمها الفرد لإنجاز المهام الموكلة إليه بطريقة أحسن", وعرفها

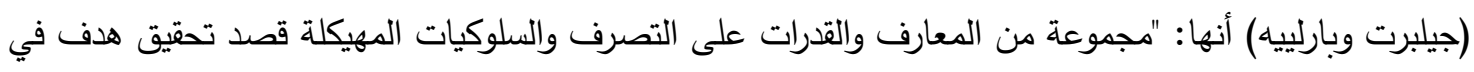

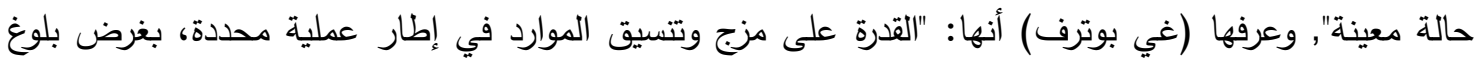

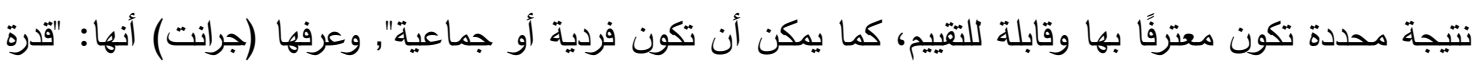

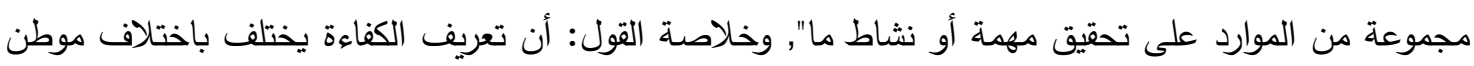
بحثها فالكفاءة في القصاص غير الكفاءة في المبارزة غير الكفاءة في الزواج, ومما سبق من تعاريف للكفاءة في مجالات مختلفة يمكن الوصول إلى قاسم مشترك بينها هو أنها: مجموعة من الملكات والقدرات والإمكانيات

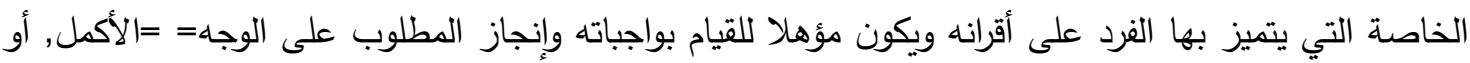

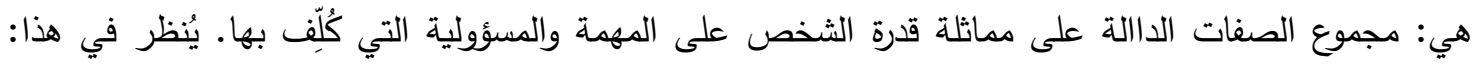
مغني المحتاج إلى معرفة معاني ألفاظ المنهاج للخطيب الثربيني سمس الدين جء صد ب rV ط دار الكتب العلمية

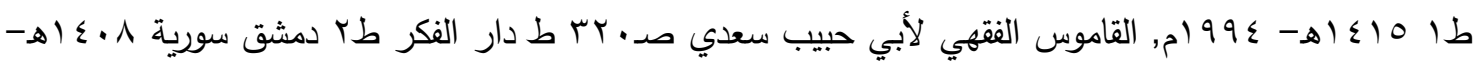

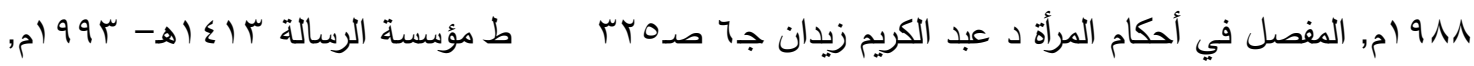

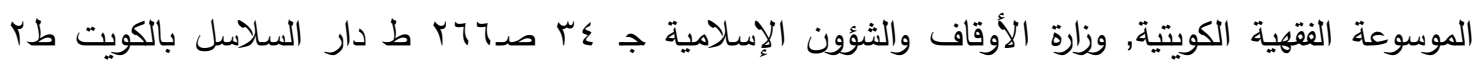

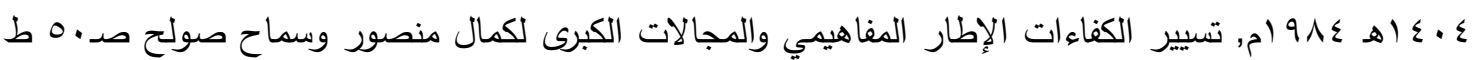

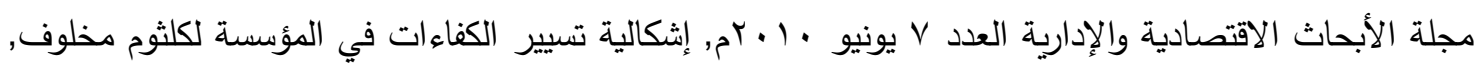
مذكرة لنيل شهادة ماستر الأكاديمي في علوم التسيير, جامعة عبد الحميد ابن باديس لإديس مستغانم، كلية العلوم

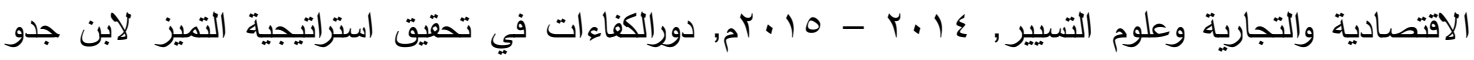

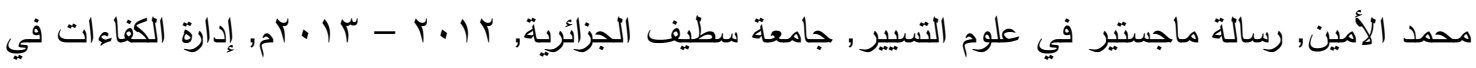
المؤسسات العمومية دراسة حالة مؤسسة عمومية جزائرية, لخديجة عميار وتسعديت ورداني, شهادة ماستر في

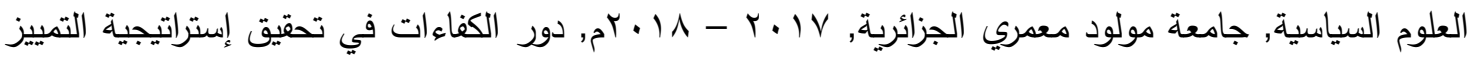

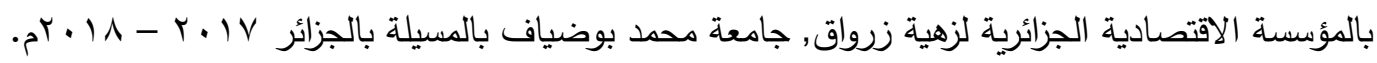




\section{حولية كلية الدعهوة الإسلاهية بالقاهرة}

كعه فقه القيادة العسكرية من خلال قصة طالوت

متى توفرت بمصداقية وشفافية, ومن رقي أو انحطاط للأمسة, وإن شئت فقل: نصر أو هزيمـة, ولأهميتها جاء الحديث عنها في القرآن الكريم وأيضـا في العهد القديم بأسـاليب ومفاهيم شتى تصب في النهاية على مدلول الكفاءة.

أولاً: نماذج من العهد القديم لقد ورد في العهد القديم: "لذلك يقول أصحاب الأمثال ايتوا إلى حشبون فنتُنْى وتصلح مدينـة سيحون"('), ففي هذا النص إشارة إلى أن رجلاً ذا كفاءة وقدرة إذا كان في المسؤولية فإنه يعدر ويقوم المعوج, وورد: "لا يبرح سفر هذه الشريعة من فمك بل تلهج فيه نهارًا وليلًا لكي تتحفظ للعمل حسب كل ما هو مكتوب فيه لأنك حينئذ تصلح طريقك وحينئذ تفلح"( ), ففي هذا النص أيضًا دلالتة على تولي صساحب الكفاءة العلميـة فيكون على يديـه الفـلاح والنجاح, وورد: "فقال الشعب لا تخرج لأنـا إذا هربنا لا يبالون بنـا وإذا مـات نصفنا لا يبالون بنـا والآن أنت كعشرة آلاف منا والآن الأصلح أن تكون لنا نجدة من المدينة"() ), وفي هذا النص أيضـاً إشارة إلى أن لن صاحب الكفاءة الخِلْقية يكون على يديه الصـلاح، وهو أجدر أن يتولى القيادة والمسؤولية؛ لأنـه يعطي القوة للضـعفاء, وورد: "والرب أعطى سـيمان حكمـة كمـا كلمـه, وكـان صـلح بين حيرام وسليمان وقطع كلاهمـا عهدًا"(") وفيـه إثـارة إلى الكفاءة العلميـة لأنـه تعلم الحكمـة التي من خلالها يكون الصلاح, وورد: "لا تسمعوا لحزقيا لأنه هكذا يقول ملك آشور : "اعقدوا معي صلحا واخرجوا إليَّ وكلوا كل واحد من جفنته وكل واحد من تينته واشربوا كل واحد ماء بئره"(), وفيه إثارة إلى أن الكفاءة الخُلُقية التي من خلالها تنقى القلوب تجعل كل إنسان في موقعه ولا يجور أحد على الآخر , وورد: "انظروا الأفضل والأصلـح مـن بني سيدكم واجعلوه على كرسي أبيـه وحاربوا عن بيت سيدكم"(†)), وفيـه إشـارة إلى الكفاءة السياسية التي من خلالها يقدم الأصلح ليكون هو المسؤول عن شؤون الرعيـة فيكون قائداً يـافع عن عربنـه وبيته, وورد: "لأنكم إن

(') الكتاب المقدس (كتب العهد القديم والعهد الجديد) سفر العدد, الإصحاح بr, الفقرة YV ط دار الكتاب

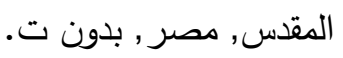

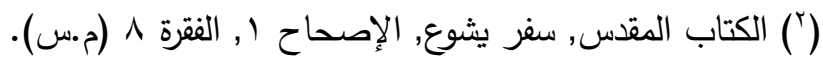

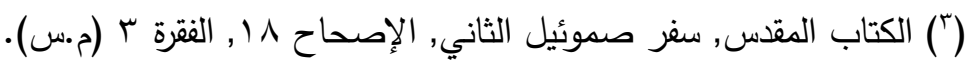
(ع) الكتاب المقد, سفر الملوك الأول الإصحاح ه, الفقرة بال (م.س). (') الكتاب المقد, سفر الملوك الثاني الإصحاح • (, الفقرة اب (م.س).

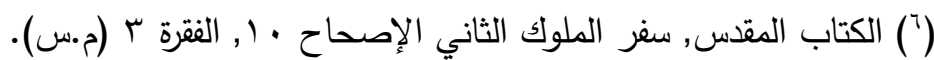




\section{حولية كلية الدعوة الإسلاهية بالقاهرة}

كهِفقه القيادة العسكرية من خلال قصة طالوت

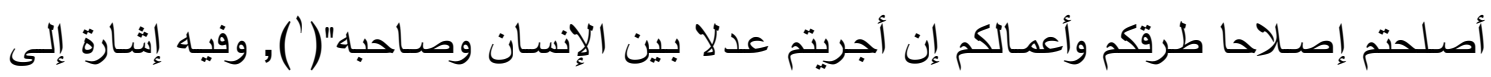
الكفاءة الإدارية والسياسية إن وُجد صاحب كفاءة فإنه يعدل بين الناس.

ثانياً: نماذج من القرآن الكريم لقد ورد في القرآن الكريم العديد من مدلولات الكفاءة وضوابطها التي من شأنها أن تُحقق

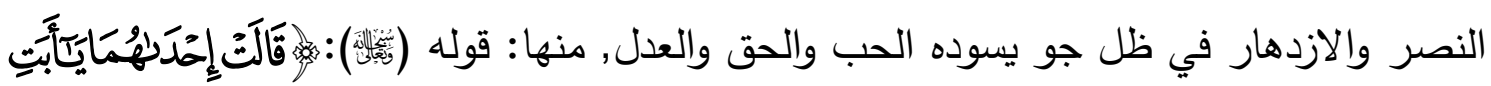

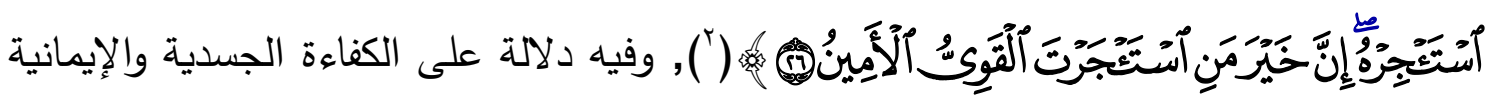

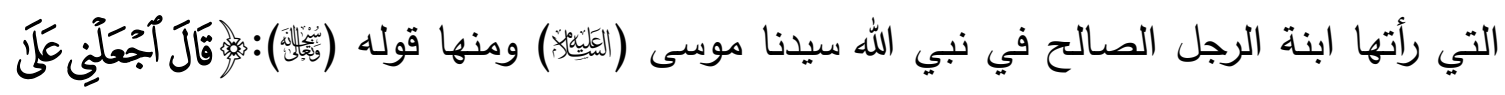

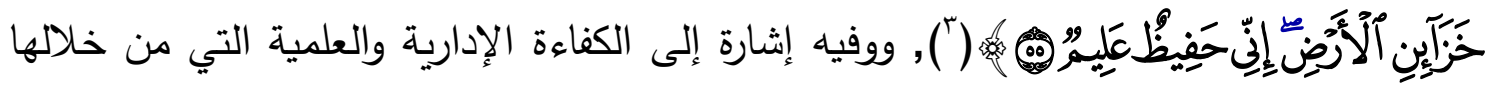

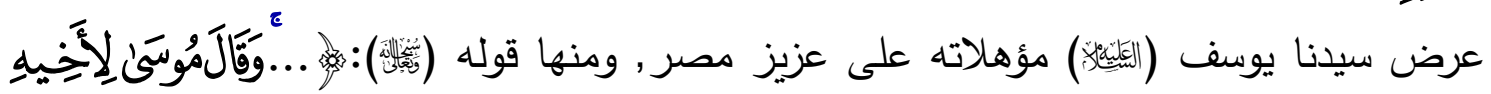

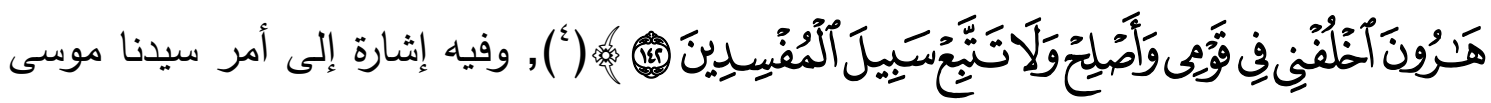

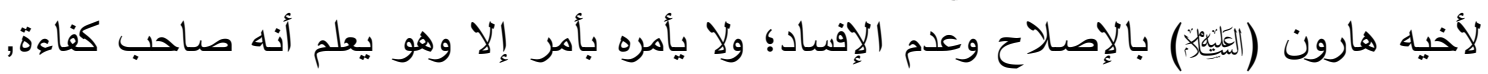

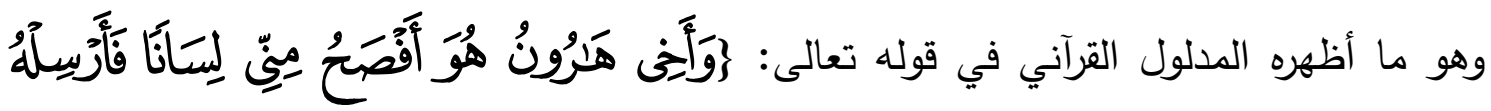

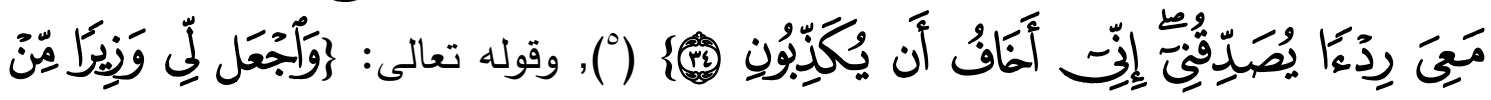

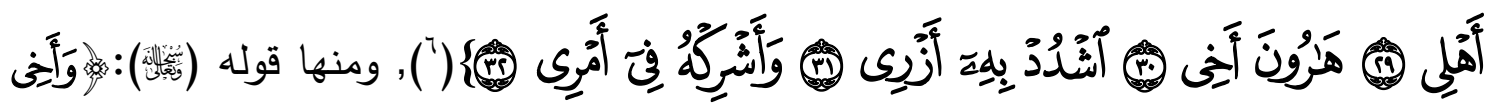

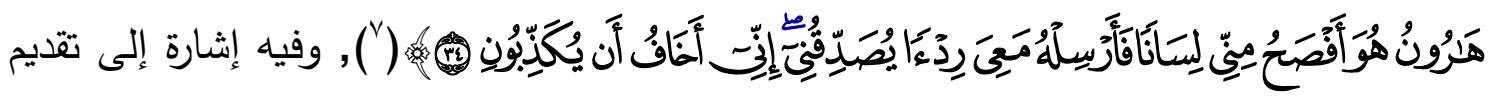

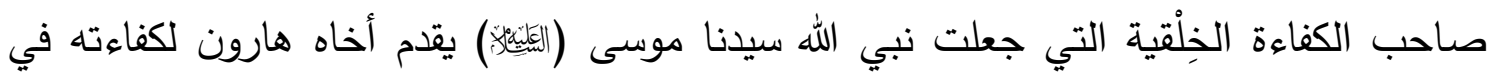

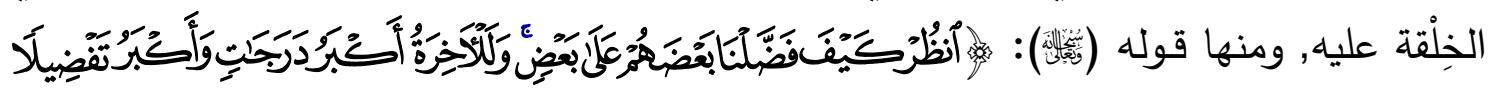

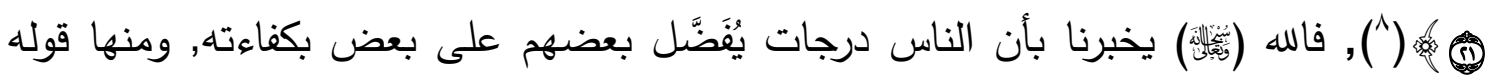

$$
\begin{aligned}
& \text { (') الكتاب المقدس, سفر أرميا, الإصحاح V, الفقرة ه (م.س). }
\end{aligned}
$$

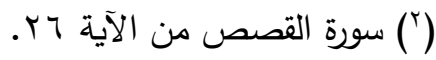

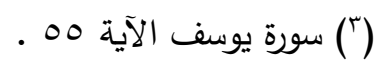

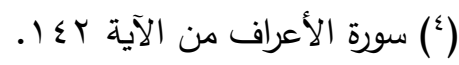

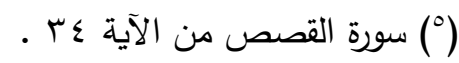

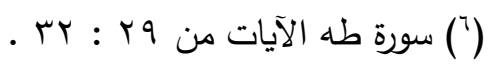

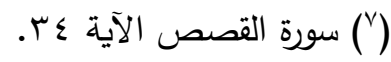

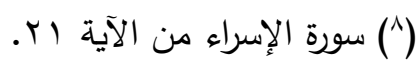


كعفقه القيادة العسكرية من خلال قصة طالوت

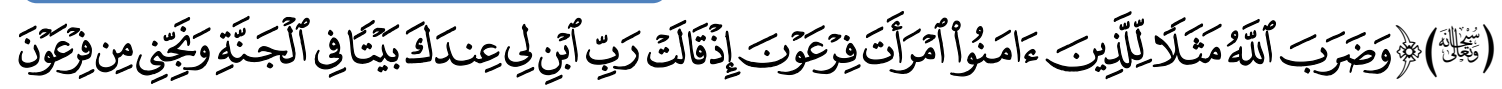

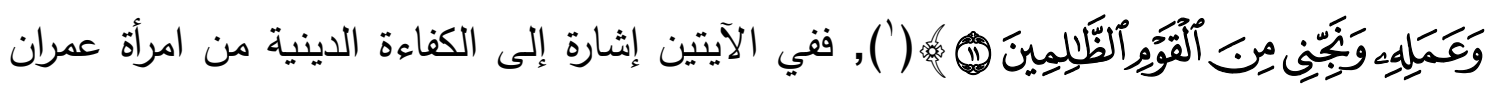
وامرأة فرعون.

إن من شأن الكفاءة بوجه عام أن تخلق عند القائد حالة من الثقة بالنفس مما يعكس عليه

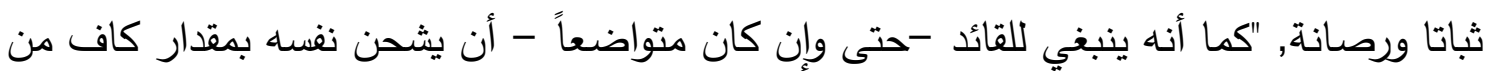

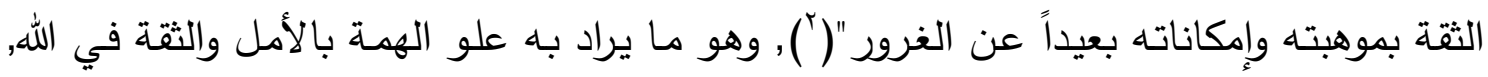

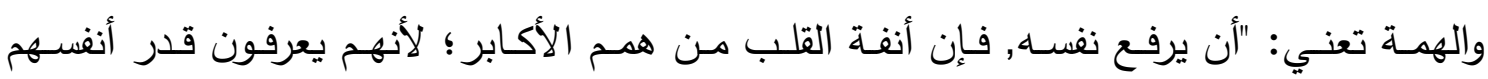

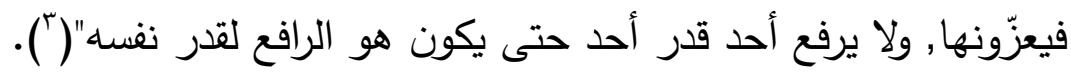

وكل هذا لا يعني قسوة القلب فهو أول عوامل الانهزام, بل إن القائد الكفه هو الذي يجمع

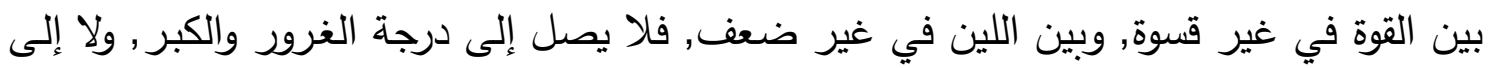

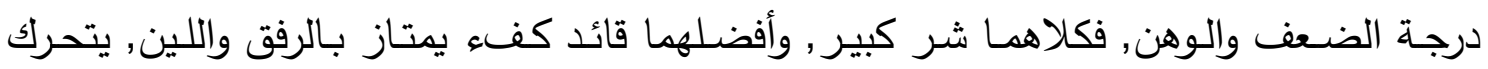

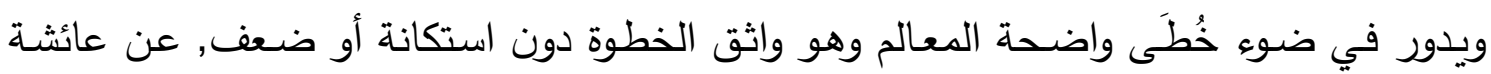

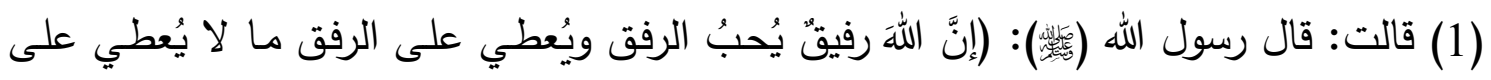

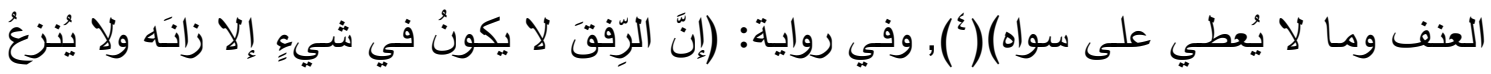

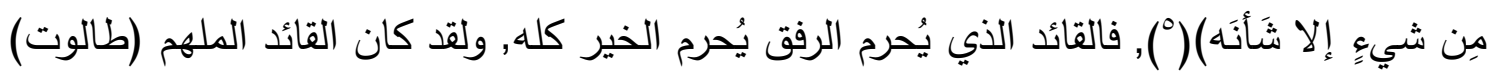

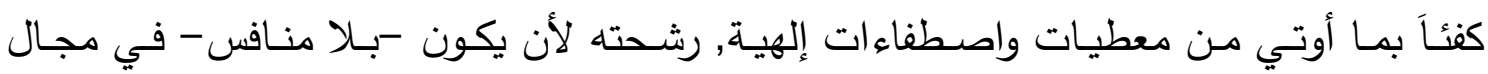
القيادة, وصار قائدا وفارسا لا يُشق له غبار .

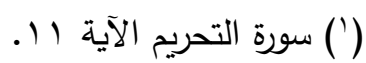

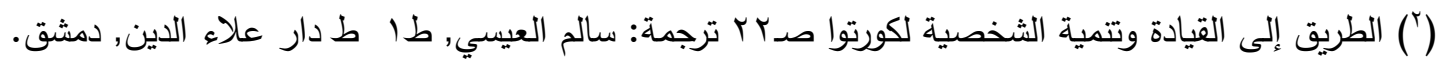

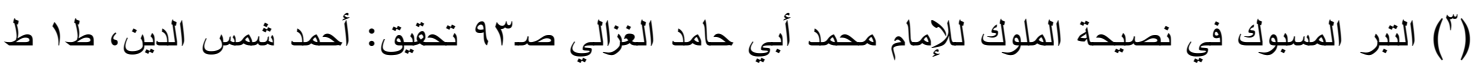

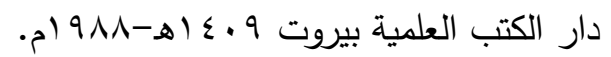

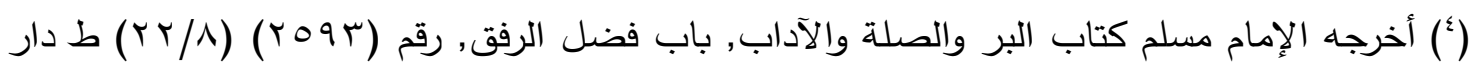
الحديث بالقاهرة.

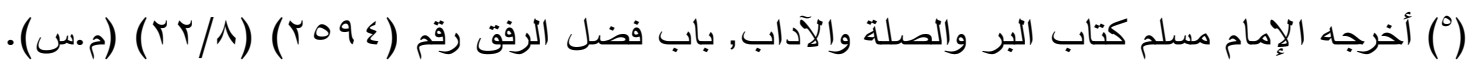




\section{حولية كلية الدعهوة الإسلامية بالقاهرة}

كهِفقه القيادة العسكرية من خلال قصة طالوت

\section{الاطلب الثاني \\ احترام ضوابط الاختيار}

ويُعنى بها: حُسن الاختيار القائم على ضوابط علمية دقيقة غايتها الحق والعدل والمصلحة العامة, ليست المجاملة والمحسوبية أو المصلحة الخاصة، حتى يلى يتسنى للقائد أن يعلو بمؤسنسته

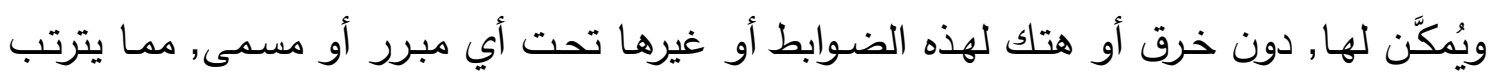

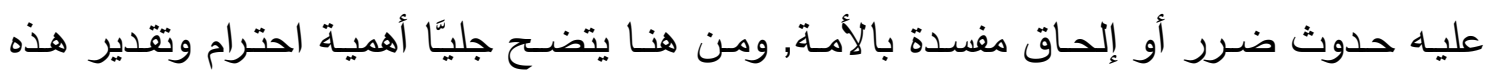

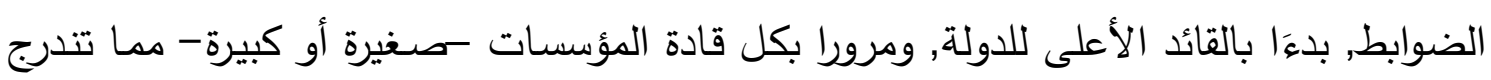
تحت قيادة الدولة.

ألا وإن هؤلاء القادة يجب عليهم أن يُؤدوا عملهم المنوط بهم بحكم الأمانـة, مقدِّرين قيمـة

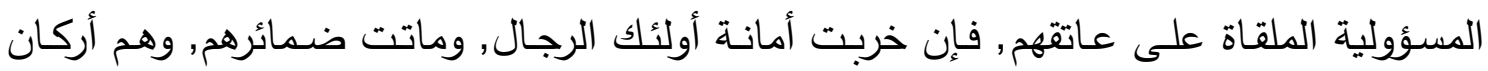

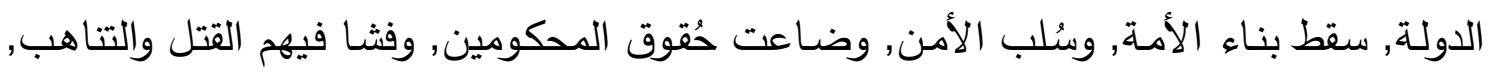

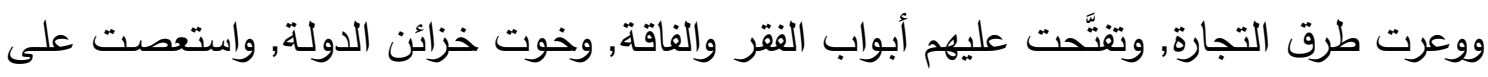

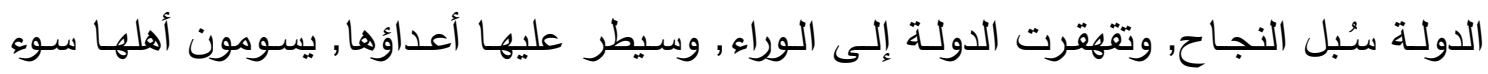

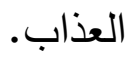

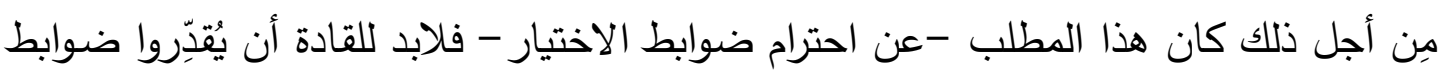

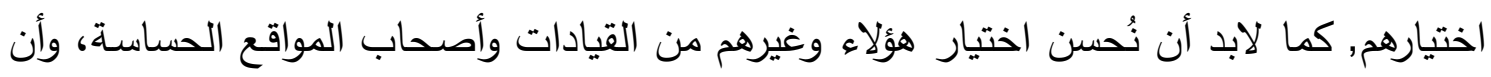

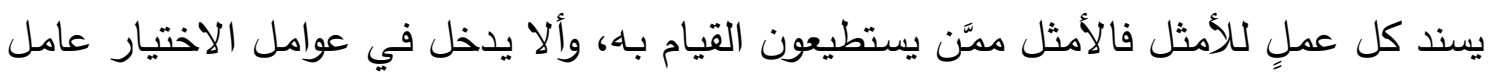

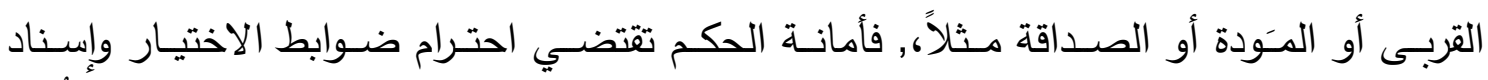

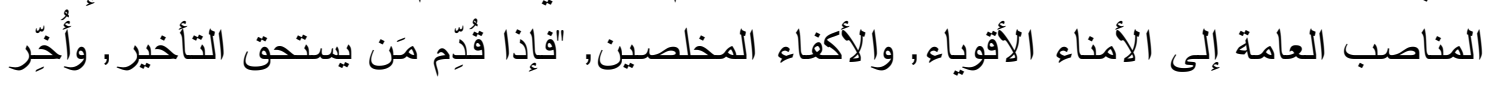

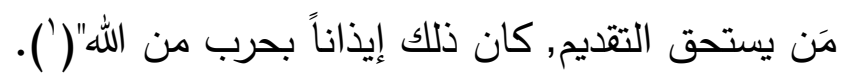

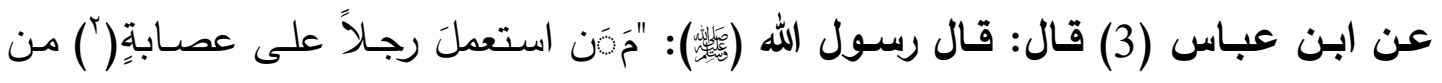

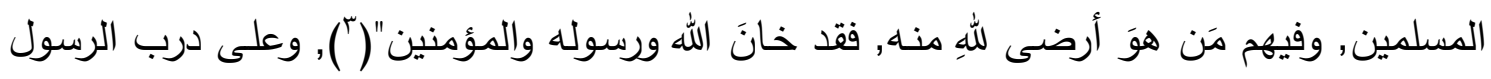

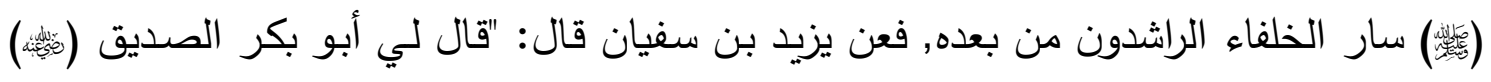

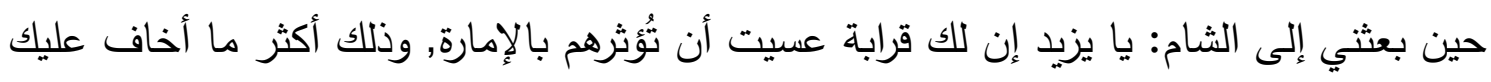

$$
\text { ' () إسلامنا للشيخ: السيد سابق صد1 } 17 \text { ط الفتح للإعلام العربي, بتصرف. }
$$

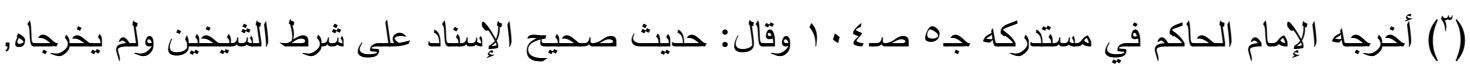

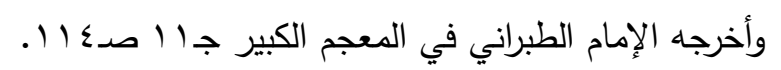


كع فقه القيادة العسكرية من خلال قصة طالوت

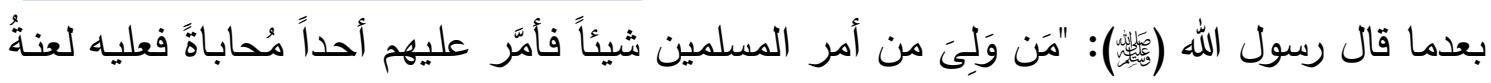

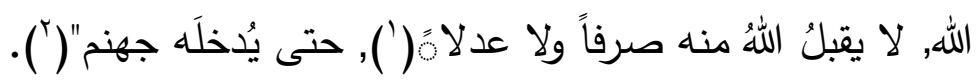
فجميع الحقوق المشروعة للمحكومين أمانة في عنق قادتها, وإنهم مسؤولون عن عن حمايتها,

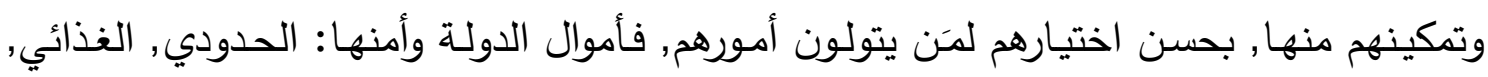

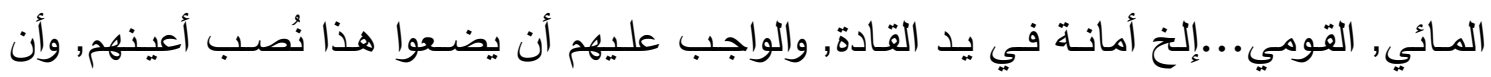
يتخذوا كل الإجراءات اللازمة لحماية هذا والحفاظ عليه بقوة وحسم دون تردد أو يد مرتعشة.

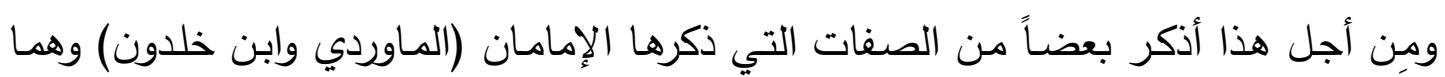

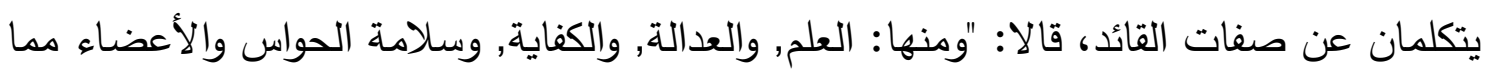

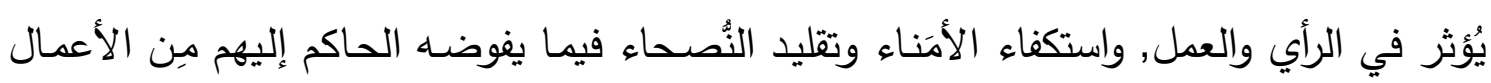
ويوكله إليهج مِن الأموال؛ لتكون الأعمال بالكفاية مضبوطة والأموال بالأمناء محفوظة, وأيضاً:

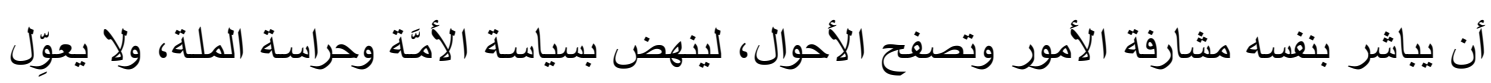

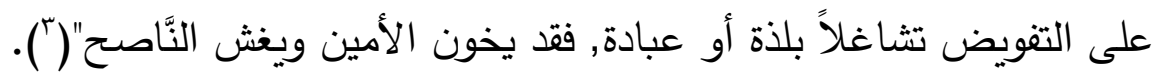

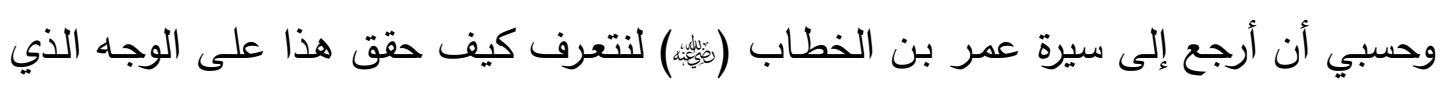

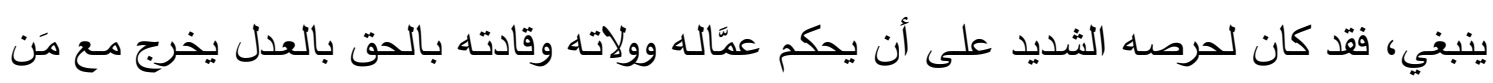

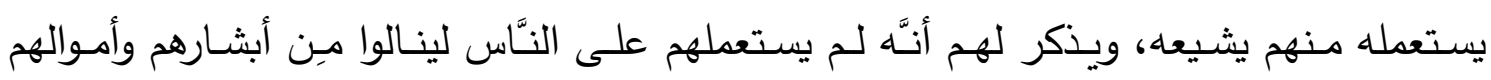

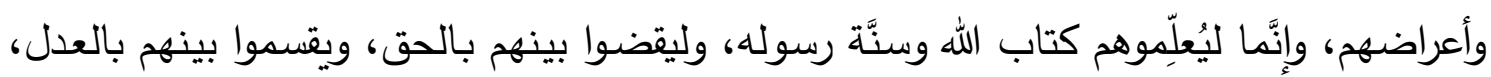

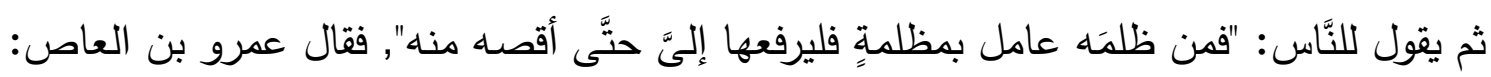

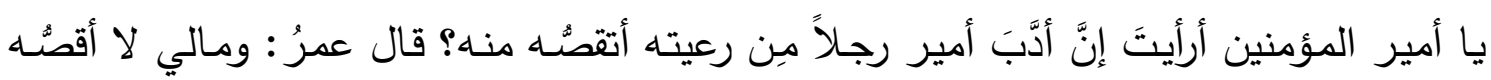

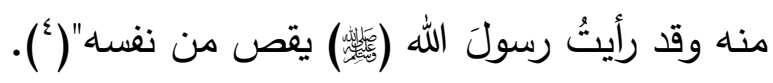
ومكمن القضية: أن احترام ضوابط الاختيار يهدف إلى النصر والظفر , والحفاظ على الرعية

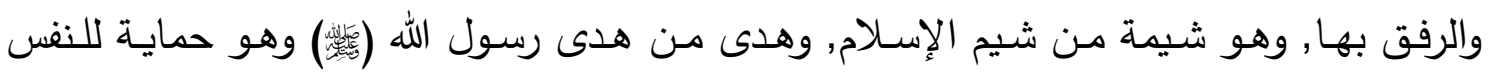

(') (') أي: لا يقبل الله منه فرضاً ولا نفلاً.

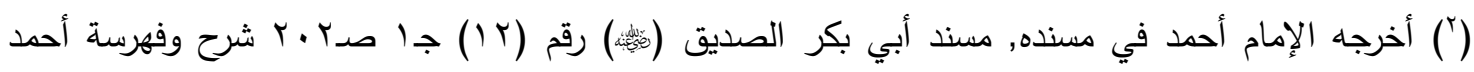

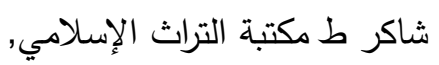

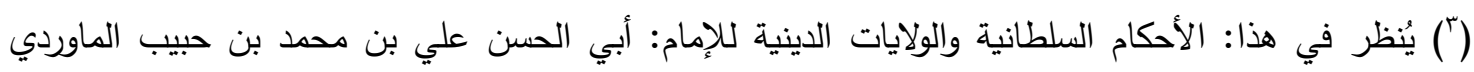

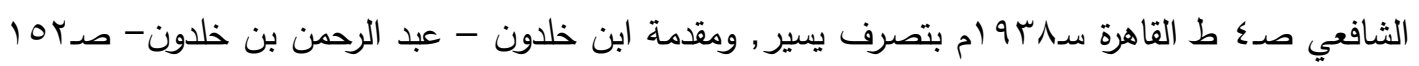

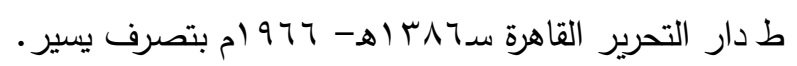

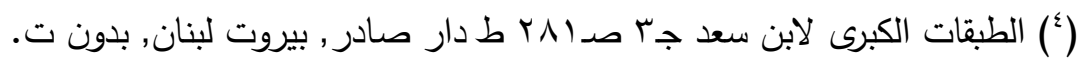




\section{حولية كلية الدعهوة الإسلامية بالقاهرة}

كهيقه القيادة العسكرية من خلال قصة طالوت

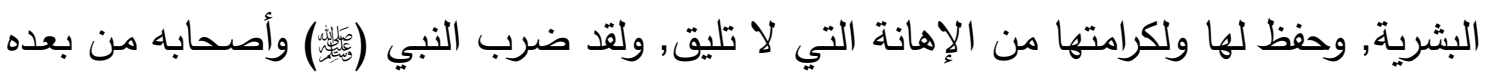

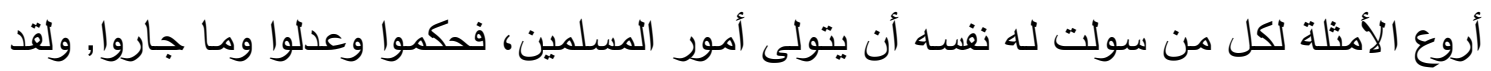

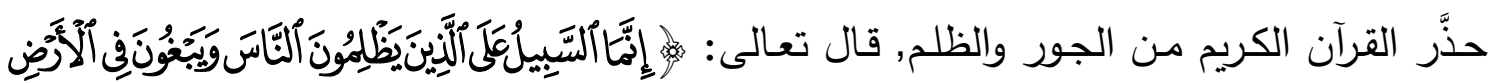

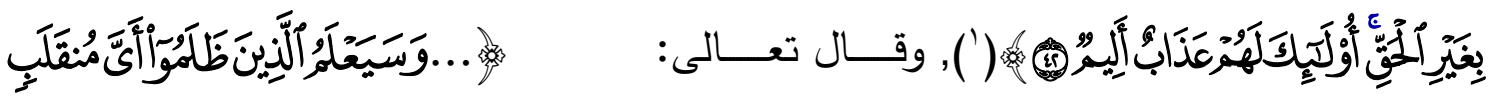

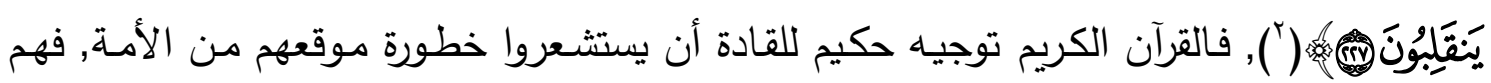

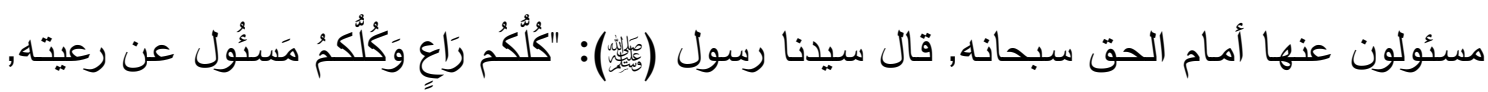

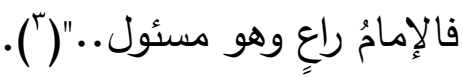

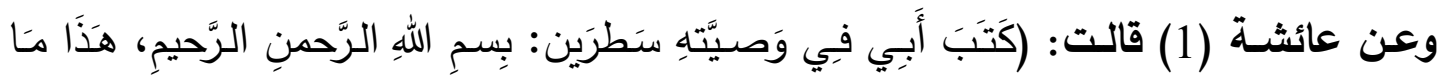

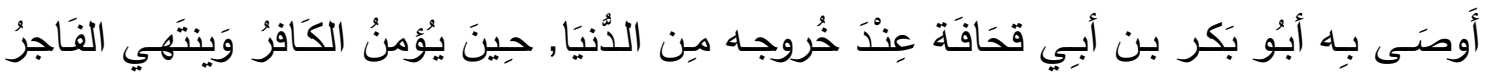

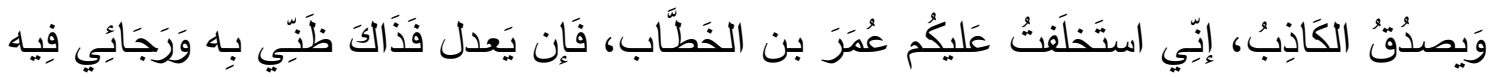

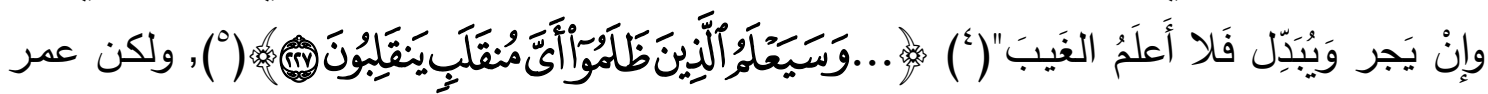

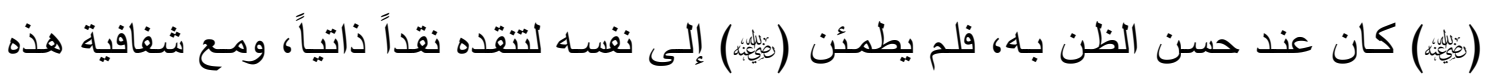

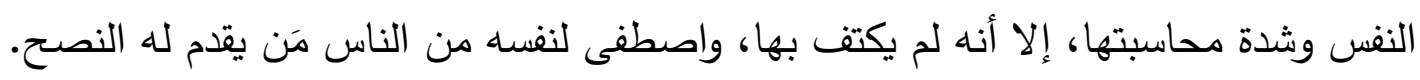

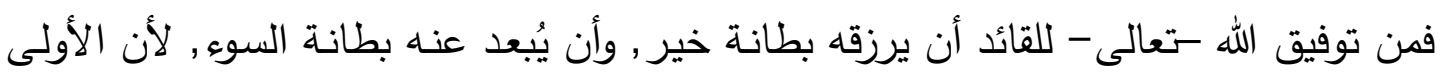

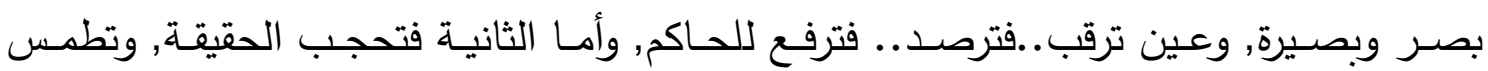

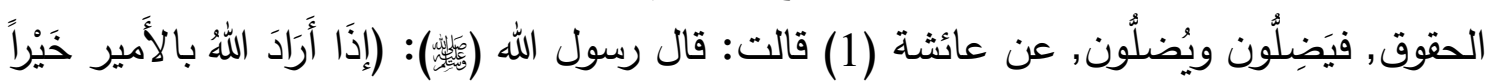

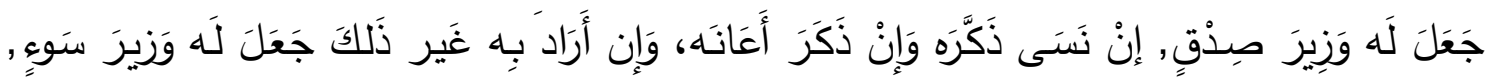

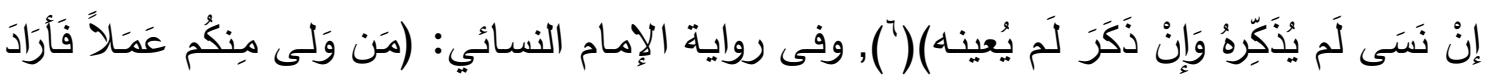

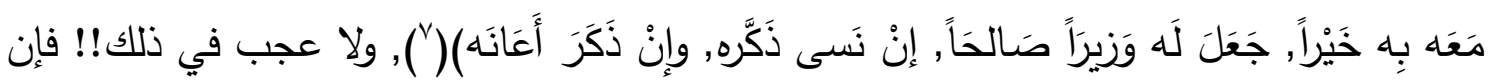

$$
\text { (') سورة الثورى الآية rآع. }
$$

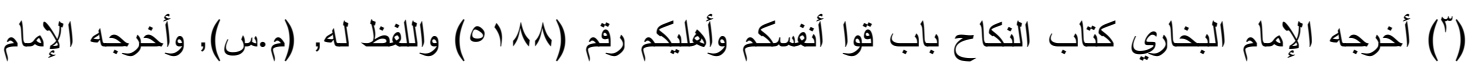

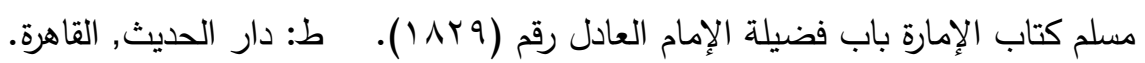

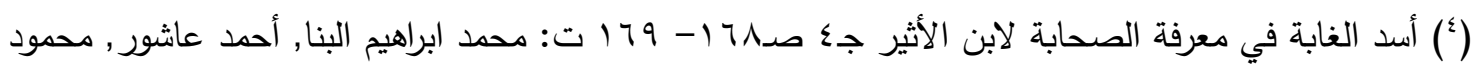

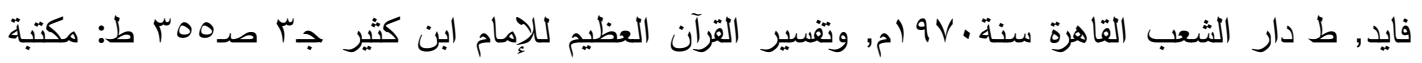

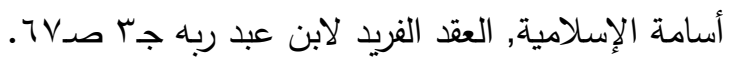

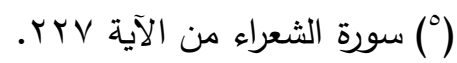

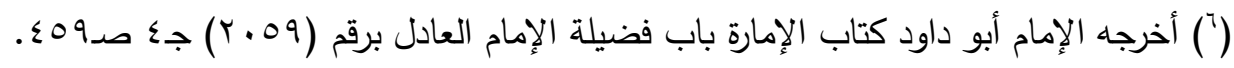

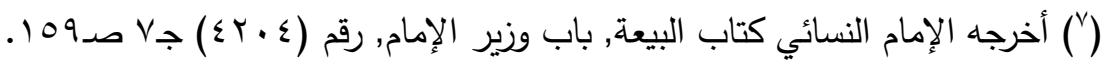


كعبقه القيادة العسكرية من خلال قصة طالوت

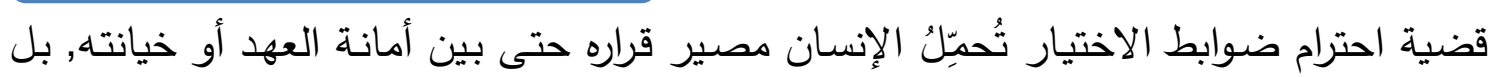
بين الإيمان والشرك, وبين الجنة والنار •

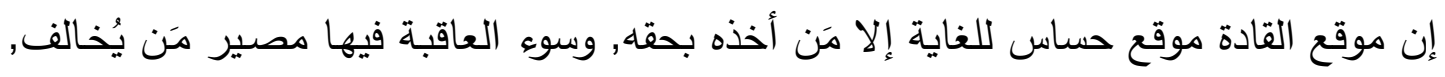

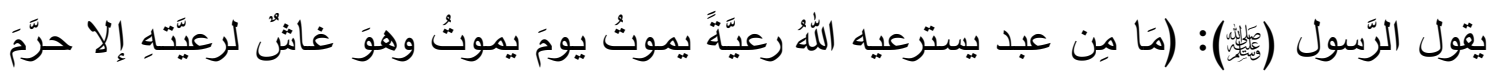

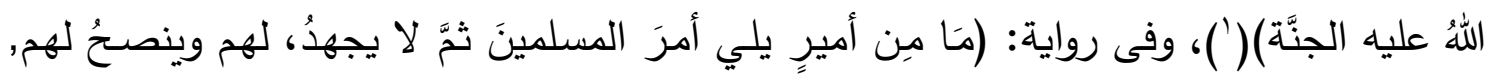
إلا لم يدخل معهم الجنَّة)( (†)، وإذا كانَ الرَّسول يحذرُ من خطورة موقع القائد ويبين أنَّ عقاب مَن

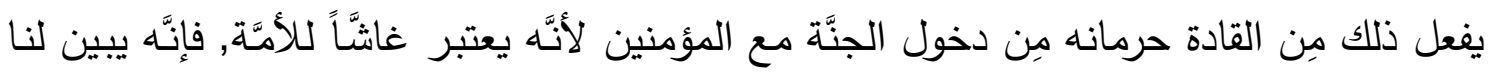

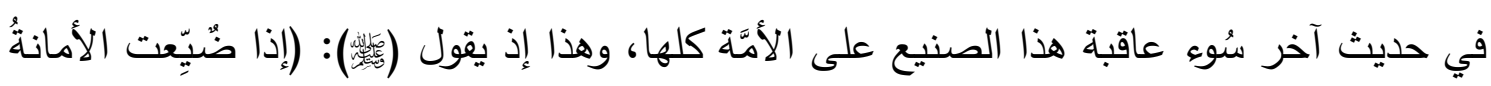

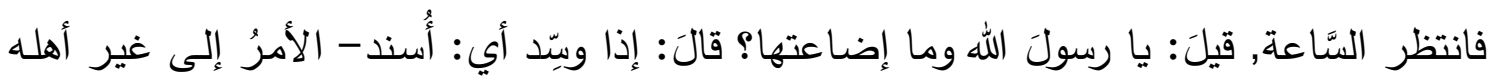
فانتظر السَّاعة)( (")، ومعنى انتظار السَّاعة: خراب أمر الأمَّة وضياعها. إن القيـادة مسؤوليات وتكـاليف لا يتحمـل الإنسـان فيها مسؤولية نفسـه فقط, ولكنـه يتحمـل

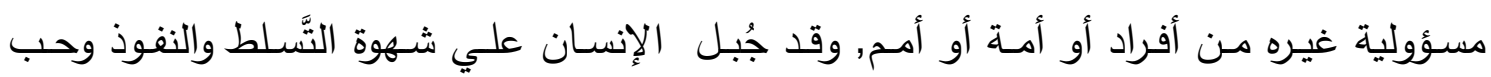
الظهور والتَّلُّك, وقد تدفعه هذه الثهوة إلى أن يسعى إلى منصب القيادة دون أن يكون أهلا لها,

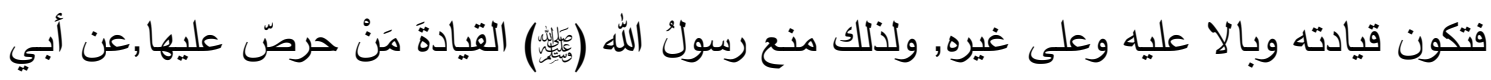

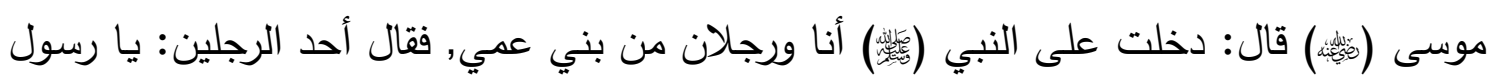

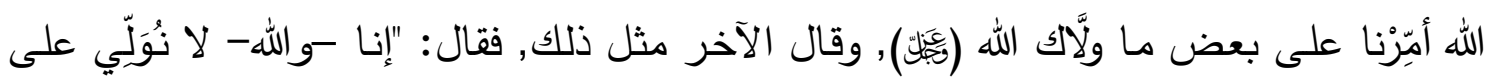

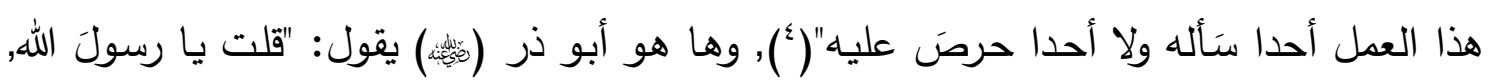

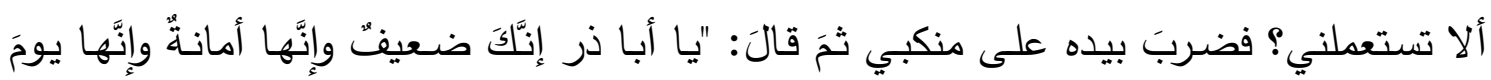

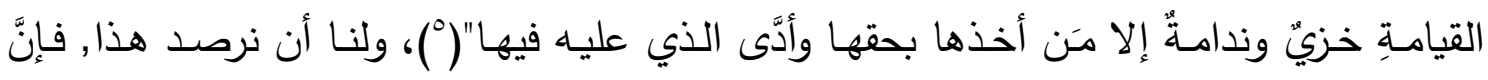

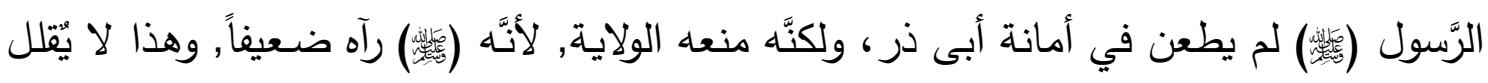

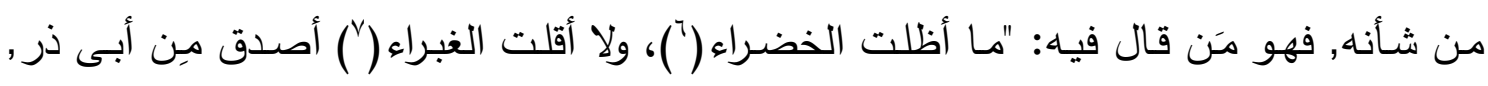

(') أخرجه الإمام مسلم كتاب الإيمان, باب الوالي الغاش لرعيته رقم (بـ ()).

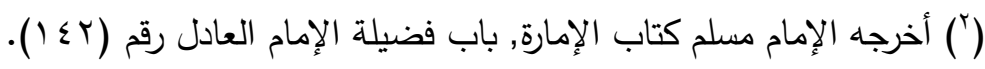

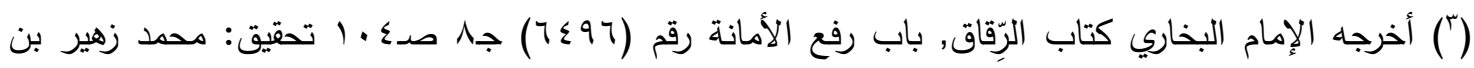

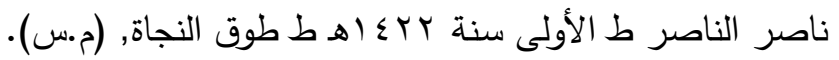

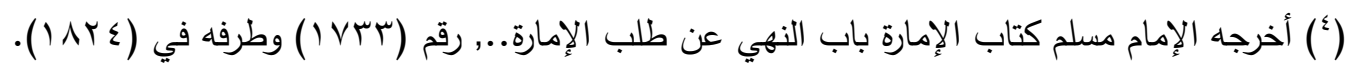

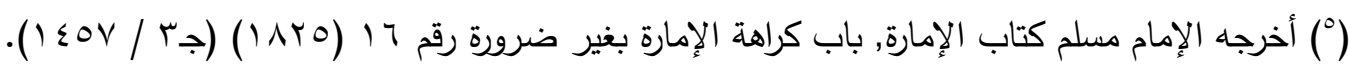

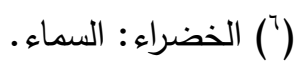

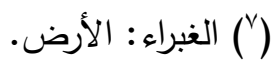




\section{حولية كلية الدعهوة الإسلامية بالقاهرة}

كعه فقه القيادة العسكرية من خلال قصة طالوت

ولكن إذا كان الإنسـان يرى من نفسـه أهـلاً لهذا المنصـب فـلا مـانع مـن طلبه, وهـا هو سيدنا

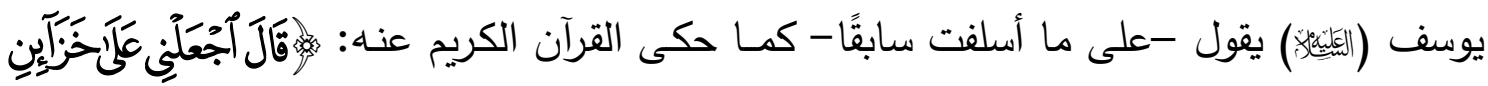

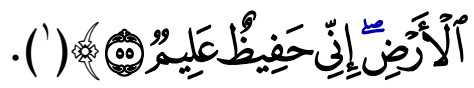

هذا, وإن لخطورة المسؤولية في هذا الموقع الحساس, قد يكون مِن القليل اجتماع القوَّة والأمانة في القادة الذين يختار منهم لتولي المناصب القياديـة، وإدارة شـئون الدولـة ـإلا مَا رحم ربي ولذلك مِن المأثور عن عمر بن الخطاب أنَّه قال: "اللهُمَ إنِي أشكو إليك جلد الفاجر وعجز الثقة", وإذن: فالإسـلام يأمر بالاختيار لكل أمرٍ أو عملٍ بحسب مـا يتطلبه مِن القوَّة أو الأمانـة، ففي إمارة الحرب مثلاً يجب تقديم القويّ على الضَّعيفِِ الأمين، وفِى أمر المال ونحوه يجب ملاحظة الأمانة قبل القَّةة..وهكذا.

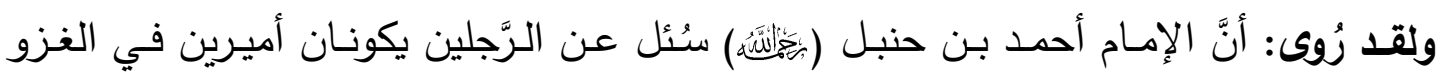

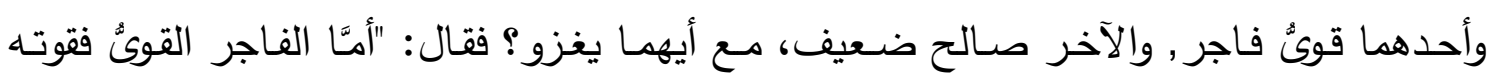

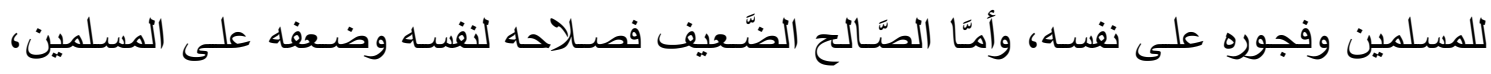

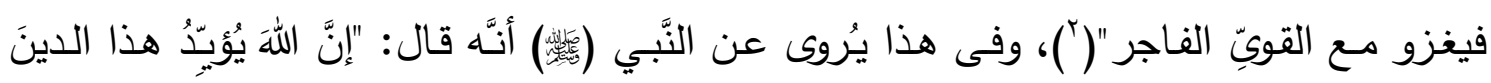

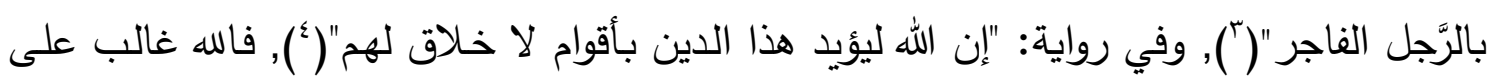
أمره ولو كره الكافرون.

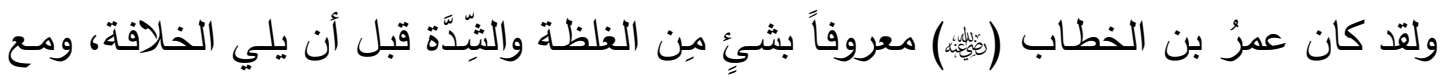
هذا فقد عهد إليه أبو بكر بعد أن استشار أهل الرأي فيه, ولكنَّ عليَّاً وطلحة (3) دخلا عليه وقالا

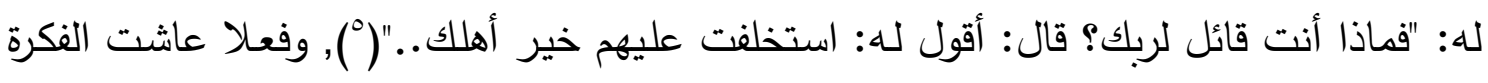

$$
\begin{aligned}
& \text { (') (') سورة يوسف الآية }
\end{aligned}
$$

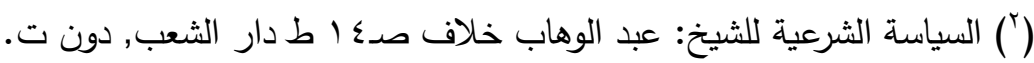

(r) جامع الأصول في أحاديث الرسول للإمام مجد الدين أبو السعادات المبارك بن محمد بن محمد بن عبد الكريم

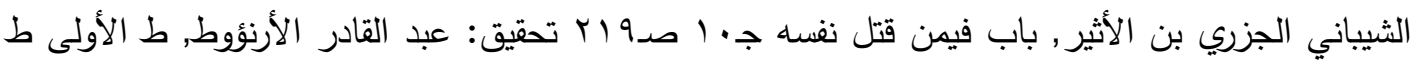

مكتبة الحلواني.

(4) السنن الكبرى للإمام أبي عبد الرحمن أحمد بن شعيب بن علي الخرساني النسائي, باب الإستعانة بالفجار في

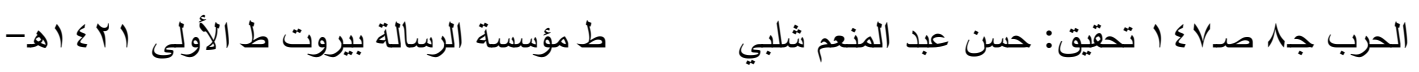

$$
\cdot \text {. }
$$

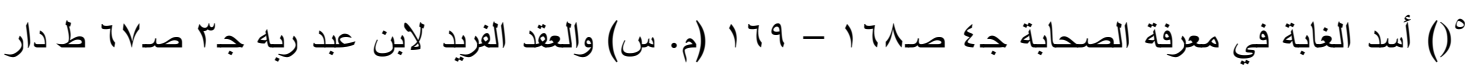
الفكر العربي. 
كئفة القيادة العسكرية من خلال قصة طالوت

ولقد عاش بها ولقي الله -تعالى - عليها, أي: إنها ظلَّت حقيقة يُعايشها طول عمره, وقد كان الفاروق فعلاً عند حُسن الظن به, فكان خير خلف لخير سلف. لقد كان لإحساسه التَّام بثقل ما وقع على عاتقه مِن تبعاتٍ ثقالٍ، وبما عليه مِن مسؤوليَّةٍة أمام

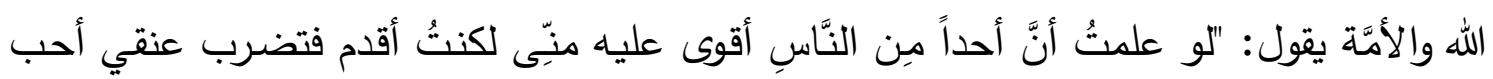
مِن أن أليه", فرحم الله هؤلاعِ القادة العظام وأمثالهم وجزاهم عن الإسلام خير الجزاء.

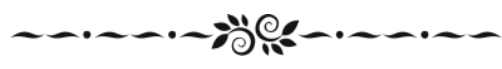




\section{المطلب الثالث \\ الدراسة العسكرية وفنون القتال}

ويُقصد بها: وقوف القائد على كل ما يتطلبه علم المدرسة العسكرية ومعارك النزال, نظريًا

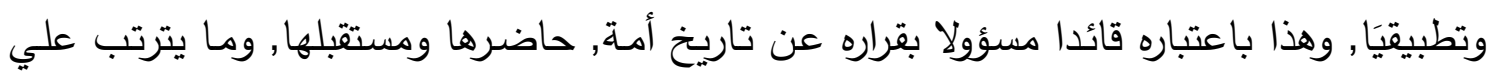

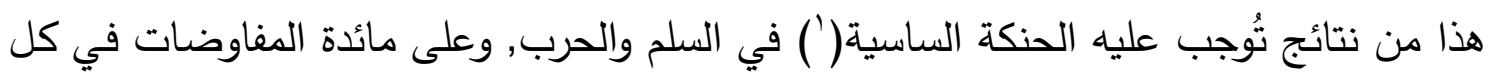

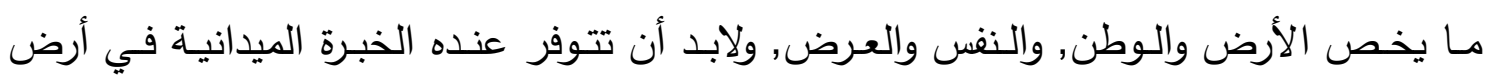

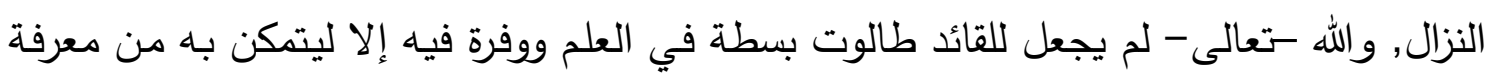

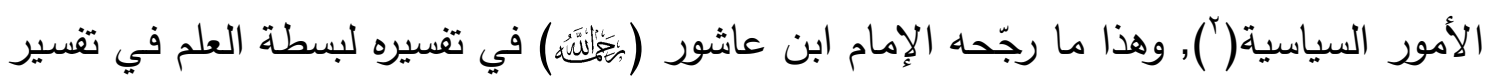
الآية الكريمة من حديث قصة القائد المُلْهَم(").

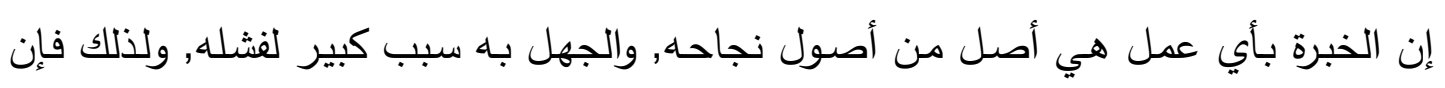

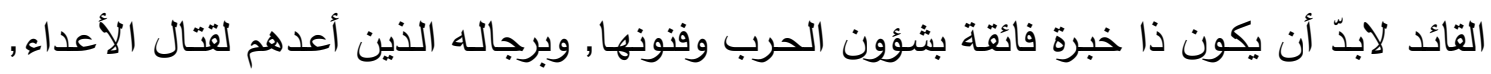

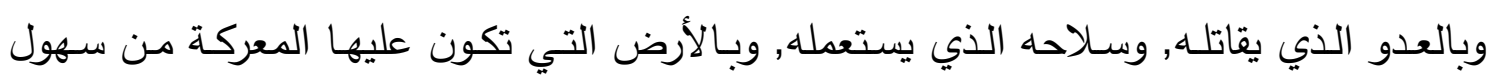

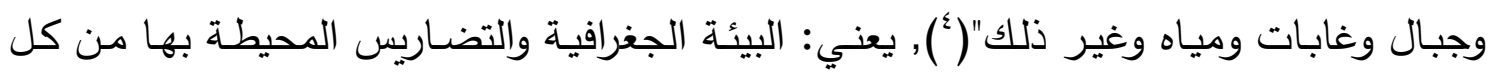
جانب, مع العلم بدراسة فنون الحروب, والاطلاع على كل حديث من آلياتها وأسلحتها وفنونها

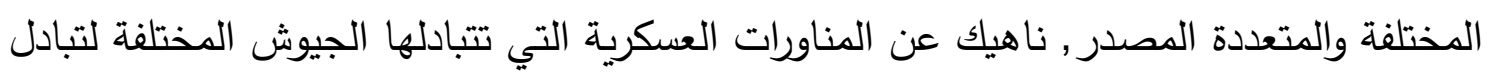

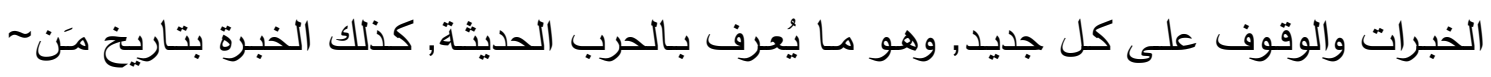

(') هي من حيث اللغة تعني: "القيام على الثيء بما يصلحه, وسُسْت الرعية سياسة: أمرتها ونهيتها, وسوِّس

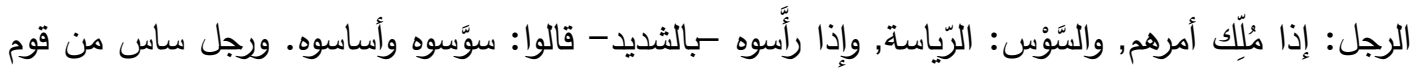

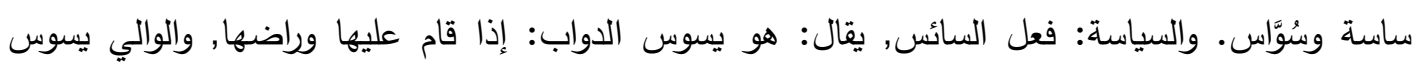

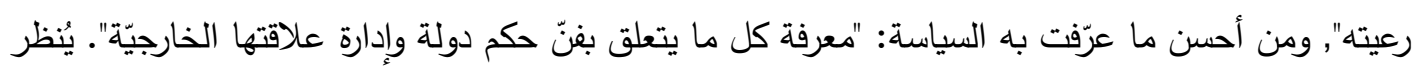

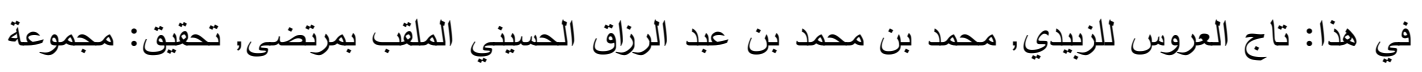

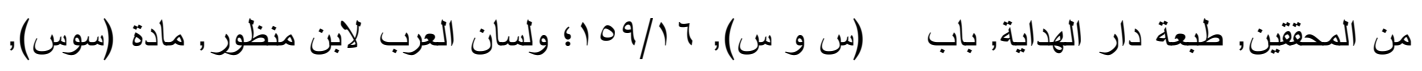

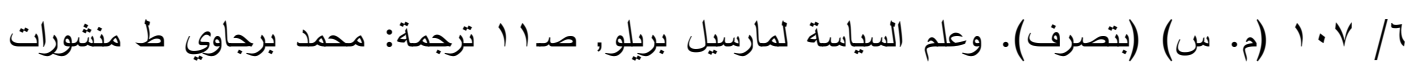

$$
\begin{aligned}
& \text { عويدات, بيروت لبنان. }
\end{aligned}
$$

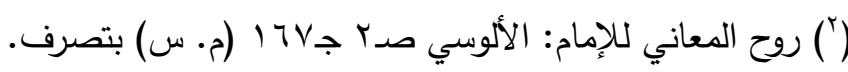

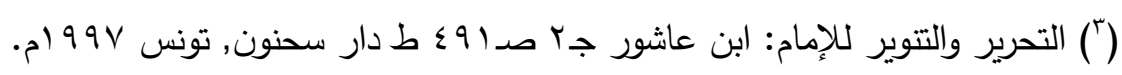

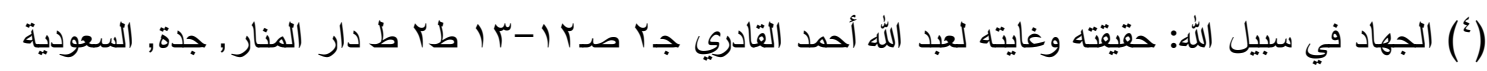

rا (الهاد 


\section{هولية كلية الدعهوة الإسلامية بالقاهرة}

كهيفه القيادة العسكرية من خلال قصة طالوت

يُحاربهم للوقوف على تراثهم الفكري ومخزونهم الثقافي والحضـاري في هذا المجال, وكل ذلك داخل في بسطة العلم.

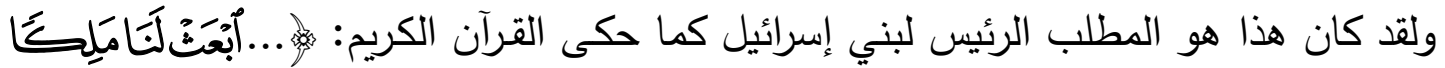

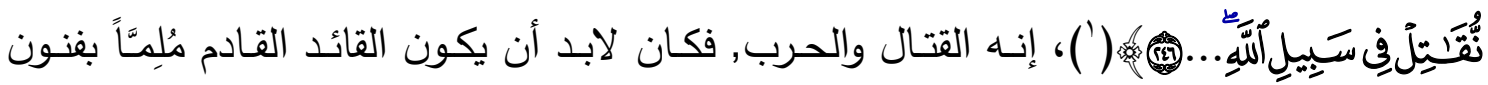
الحرب والنزال, إذ هي المقصود الأول من اختياره, وهذا ما توفر في القائد المُلْهَمُ طالوت, فعن ابن عباس (3) قال: "كان طالوت أعلم بني إسرائيل بالحرب"()), وهو ما أيده الإمام الكلبي

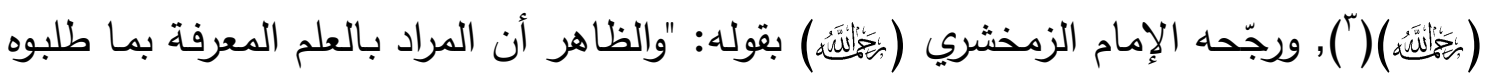

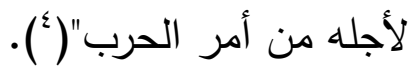

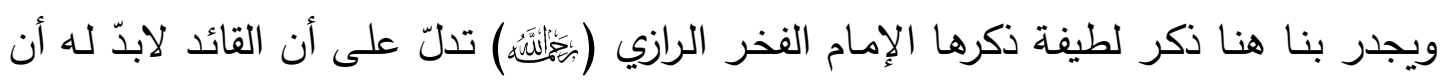
يكون عالي الهمة في التطوير الذاتي الدائم لعلمه, وأن لايقف عند حد معين ولو كان مَلكِاً, حيث

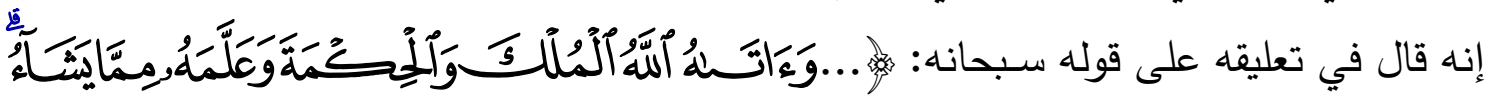
...

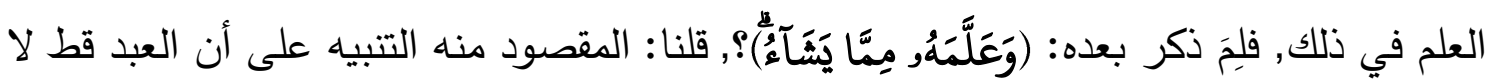
ينتهي إلى حالة يستغني فيها عن التعلم, سواء كان نبياً أو لم يكن, ولهذا قال سبحانه لسيدنا

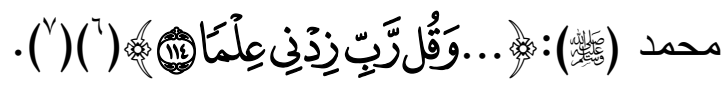
فيتبين لنا بذلك أن العلم في الآية الكريمة يدخل فيه العلم بالثؤون العسكرية وفنون القتال التي

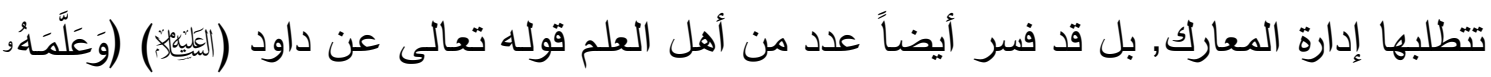

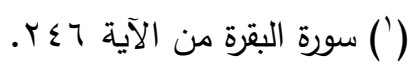

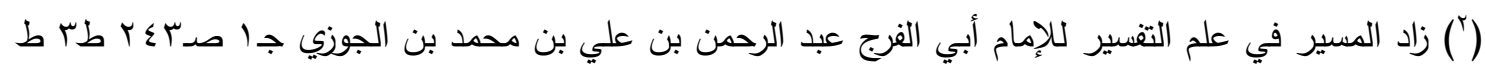

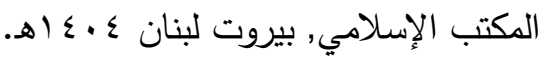

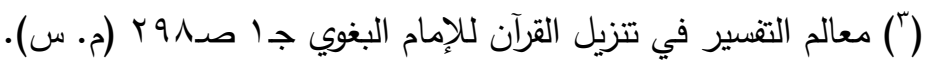

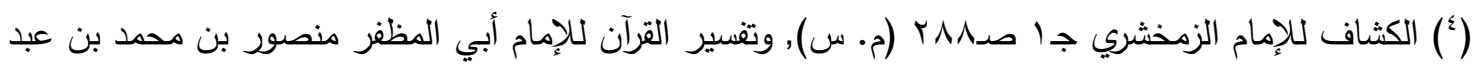

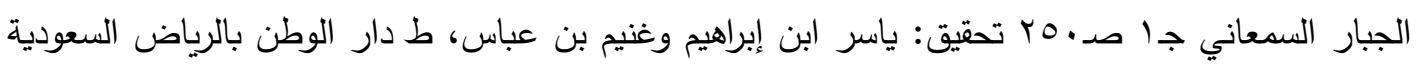
. $99 \vee-ه 1 \leqslant 11$

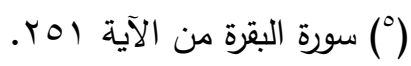

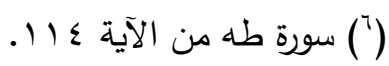

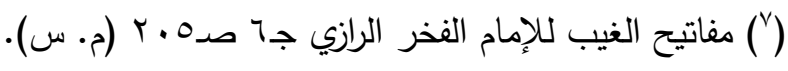


كع فقفه القيادة العسكرية من خلال قصة طالوت

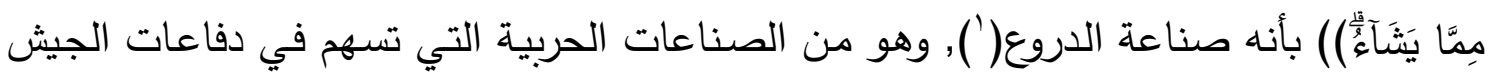
وتعزيز موقفه, ولا يوجد في تاريخ بني إسرائيل دلالة على قيام جيش قوي ومنظّم إلا في عهد القائد المُلْهَم (طالوت), ومما يؤكد مهارته وعلمه بفنون الحرب والقتال, سياسته الرائعة في إدارة دفّة المعركة لصسالحه, حتى حظى بالنصر والظفر , وتمكن من بتر دار الأعداء, وهو ما حكاه

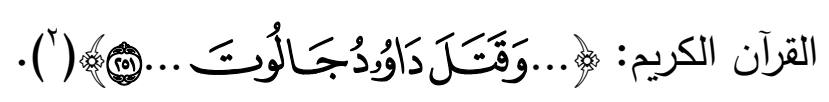

كما أن من شأن الدراسات العسكرية الناجحة أن تُخرِج قائدا يمتلك فن القيادة في التعامل مـع جنده وقواده, وهو ما يُعرف بفقه القيادة لدى القائد الفارس, ولقد أجمع قادة الحروب العسكرية في العصر الحديث على أن القائد الناجح لابد أن يمتلك فن الاتصال, والتواصل الدقيق والعميق بينه وبينـه جنده, أو أفراد مؤسسته, وهو مـا يتوفر نتيجـة مجموعـة مسن الضـوابط والأسس النظريـة والتطبيقية, وعلى رأس ذلك دور الكلمة ومدى تأثيرها على نجاح أي قائد, ولذلك نجد بين أنواع الخطابة: الخطابة الحربية التي يُلقيها القائد لجنده حتى يُشمِّروا عن ساعد الجد في شجاعة وإقدام

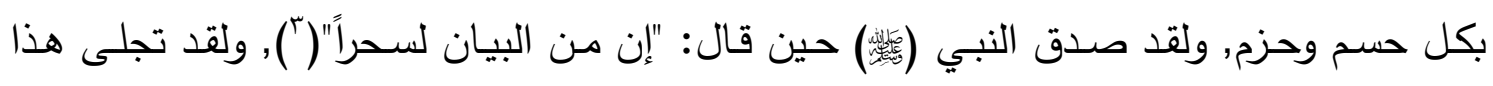
واضحا بين ثنايا القصة من خلال مخاطبة القائد الْمُلْهَم لبني إسرائيل, فقد خاطبهم بكل فصاحة وبيان لاقناعهم والتأثير عليهم.

ومن هنا تأتي خطورة الكلمـة التي تُمثِّل عند القائد الحياة أو الموت, عن عبد الله بن عمر

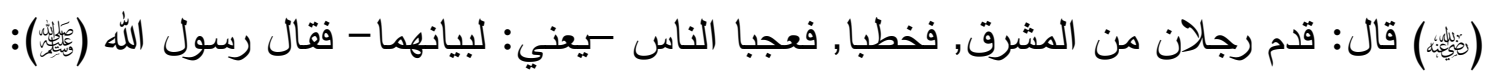

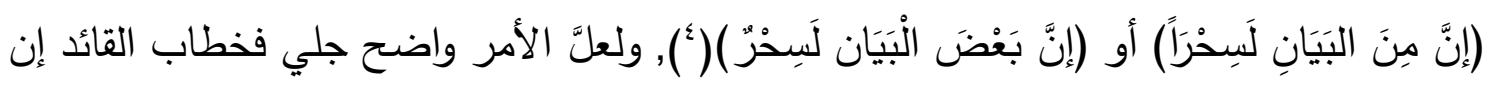
كان فيه إطناب ممل, واستطراد غير مقبول, تشمئزه النفوس الآذان, ولا ترتاح له العقول, يرفضـهـ الجندي المقاتل, أو الفرد داخل المؤسسة, فيُدبر عنه غير مُقبل عليه, ولا شك فإن للقلوب إدبارًا وإقبالًا, فهي مقبلة على ما تُحب وتعشق, ومدبرة عن كل تشمئز وتكره. كما أن الكلمة الآسرة من القائد من شأنها أن تجذب الأبصار والعقول, وهذا خطرها إذ قيلت في غير موضعها, عن عبد الله بن ثابت (نِيّ⿰幺幺) قال: حدثي صخر بن عبد الله عن أبيه عن جده

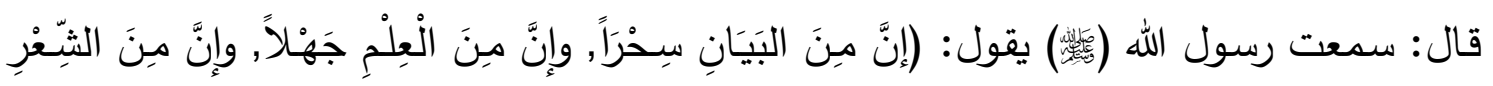

$$
\begin{aligned}
& \text { (') معالم التقسير في تتزيل القرآن للإمام البغوي جا صد •ب (م. س). }
\end{aligned}
$$

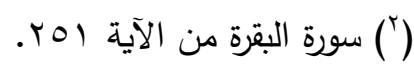

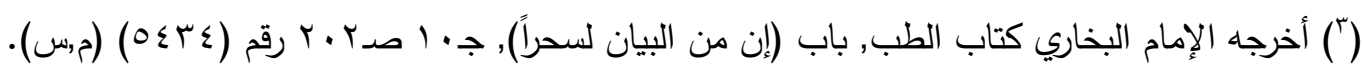

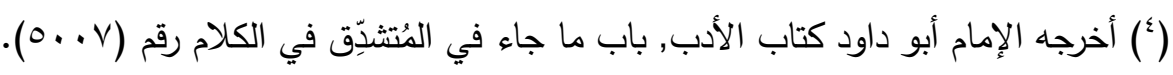


كهيقفه القيادة العسكرية من خلال قصة طالوت

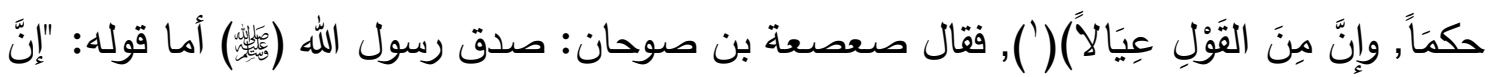

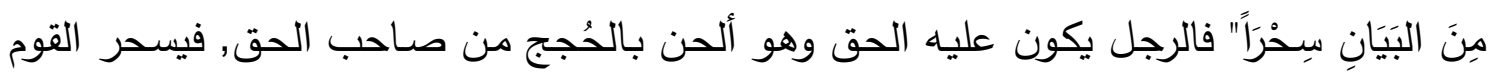

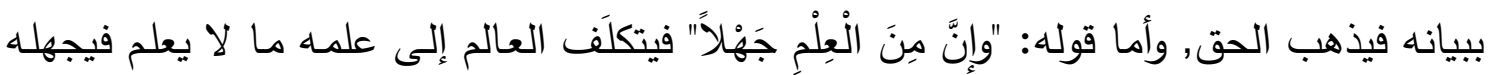

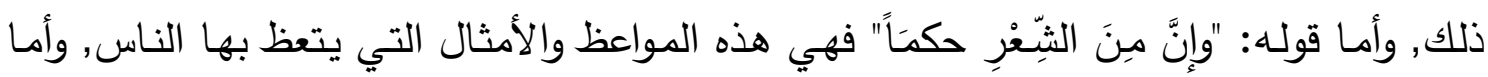

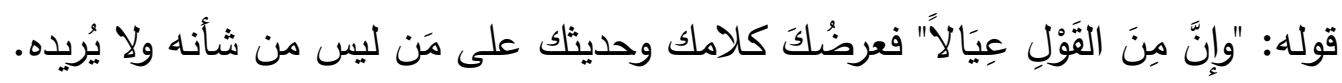
كما أن مواقف الحسم وظروف النزال تتطلب من القائد الإيجاز والتعبير بدقة وعمق مراعاة

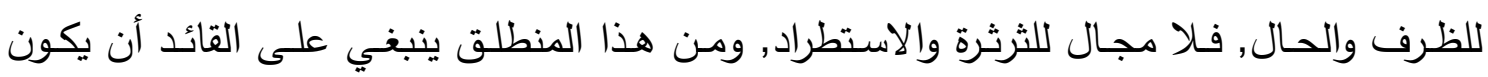

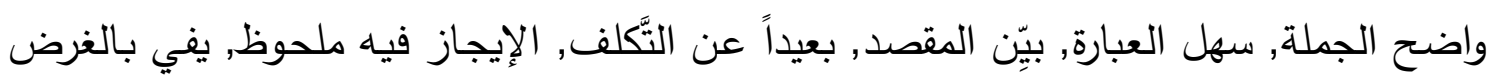

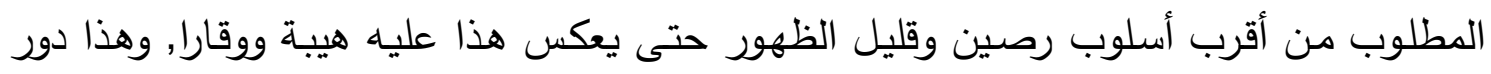

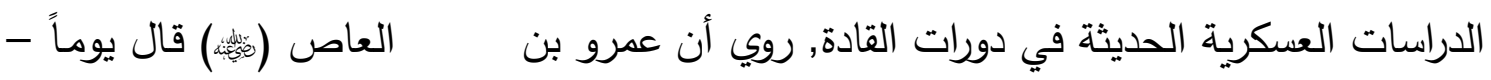

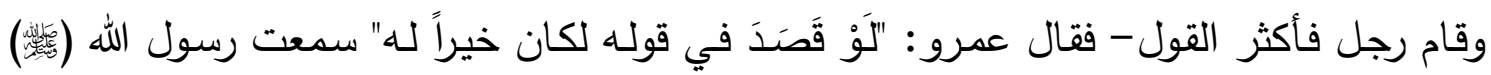

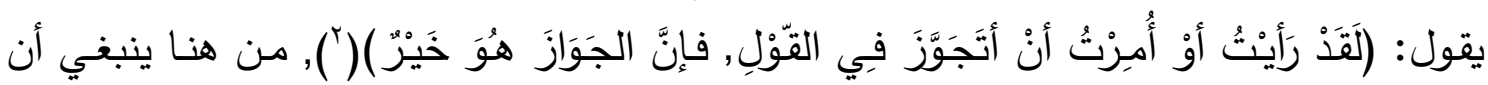
يفرض المقام نفسه على المقال, فلكل حدث حديث, ولكل مقام مقال, وكما قالوا عن فن القيادة: القائد كلمة, فليتدبر •

هذا, وإذا كانت كلمات القائد تُعدُ عليه -ولابد أن تكون بميزان - فإن هذا لا يتتافى مع أخذه

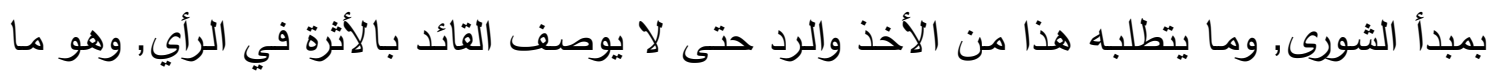

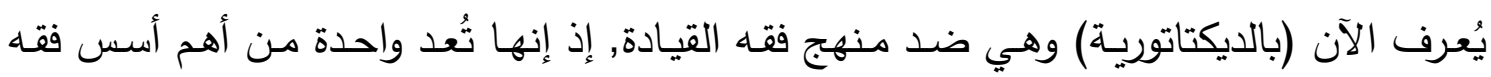

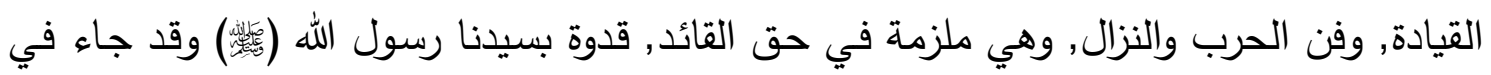

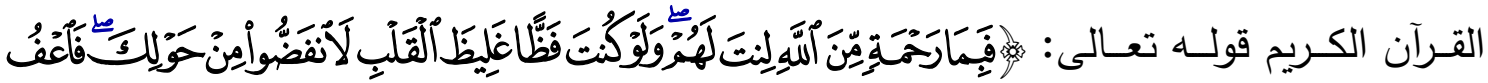

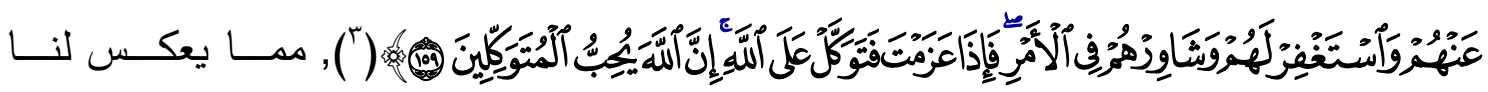
مكانة الثُورى وأهِيَّيَّها في فن القيادة.

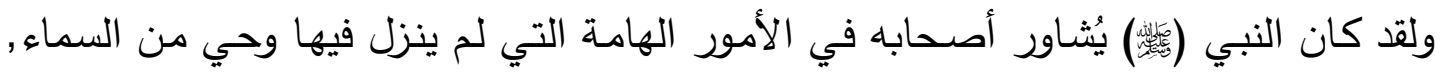

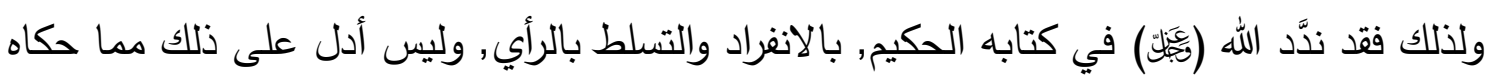

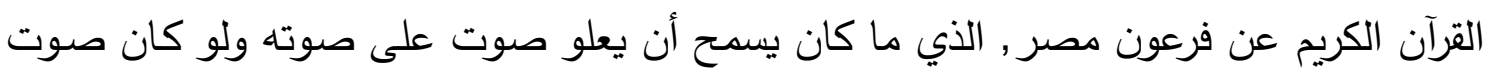

$$
\begin{aligned}
& \text { (') أخرجه الإمام أبو داود كتاب الأدب, باب ما جاء في الثعر , رقم (r ا م). }
\end{aligned}
$$

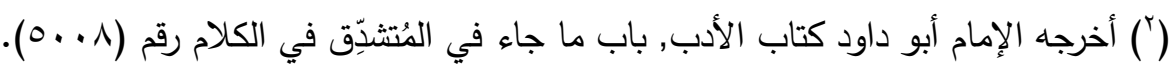

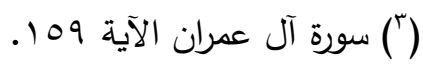




\section{هولية كلية الدعموة الإسلاهية بالقاهرة}

كهُفقه القيادة العسكرية من خلال قصة طالوت

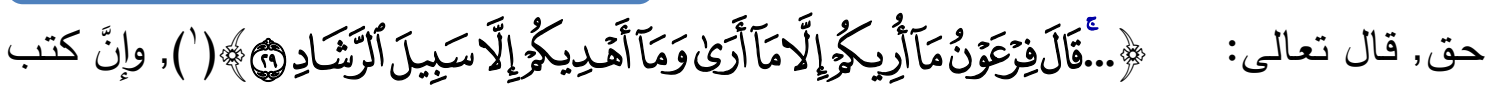

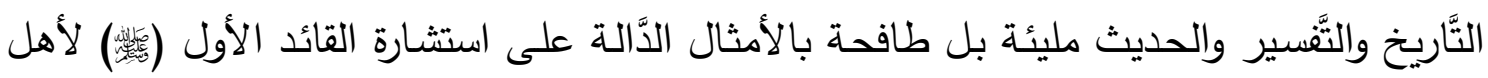

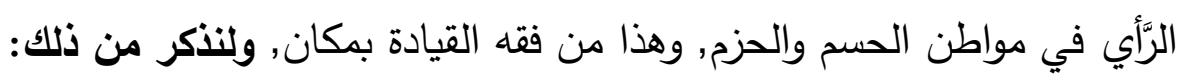

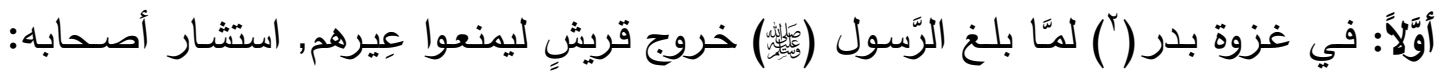

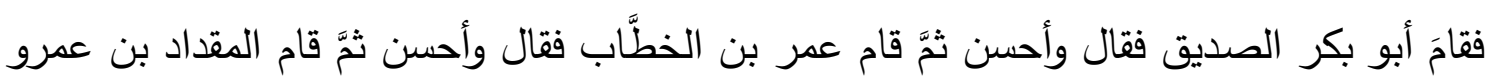

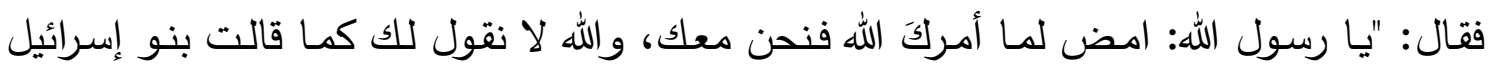

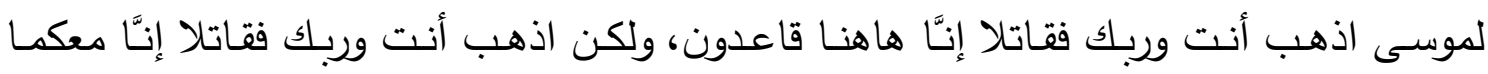

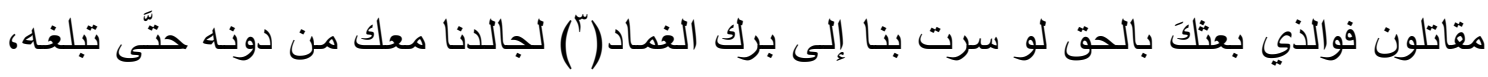

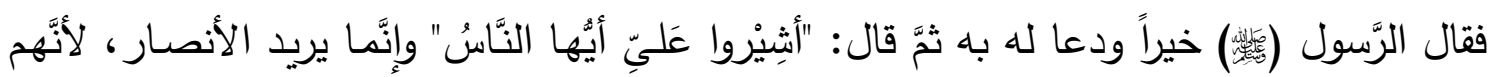

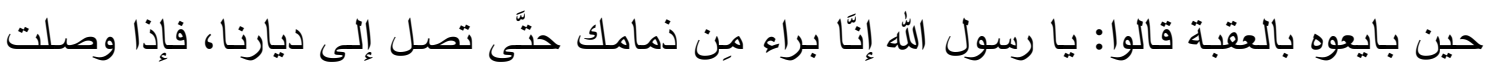

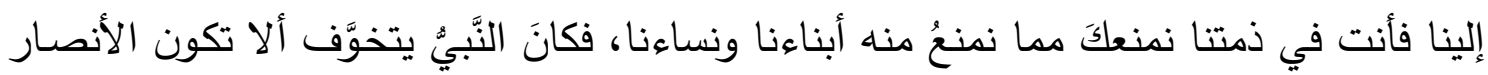

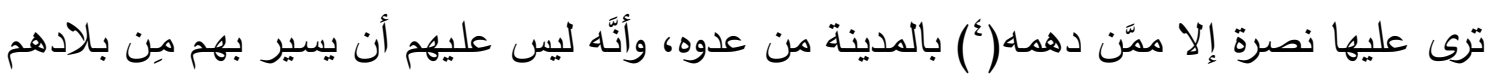

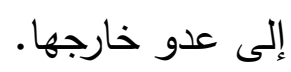

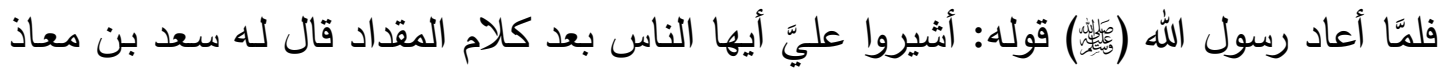

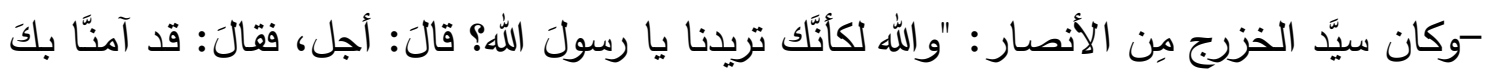

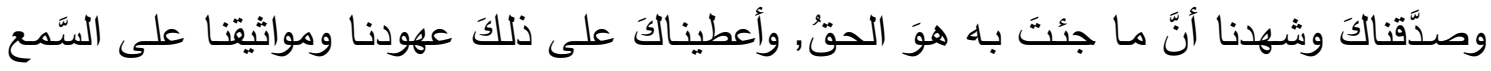

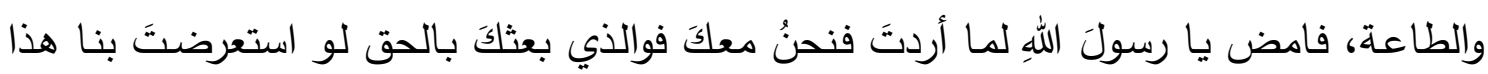

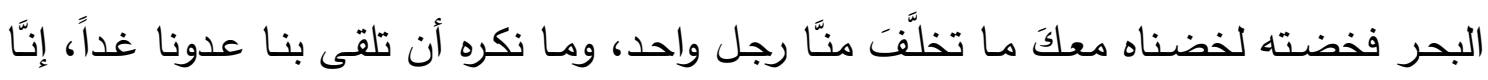

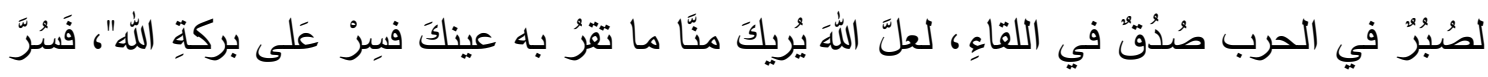

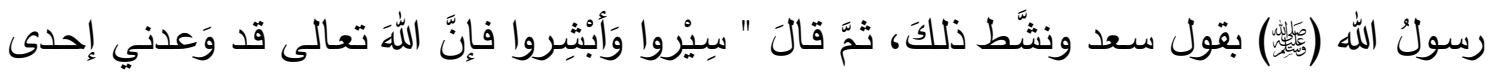

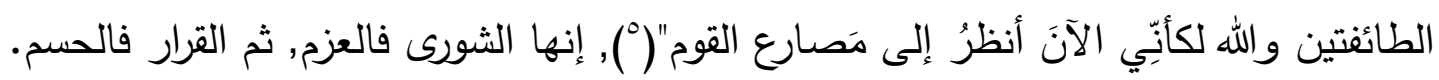

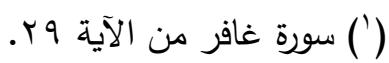

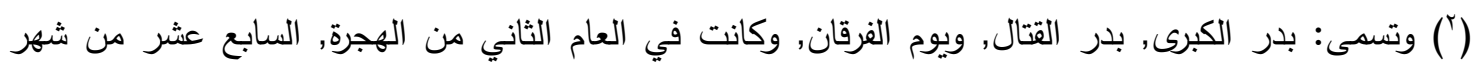

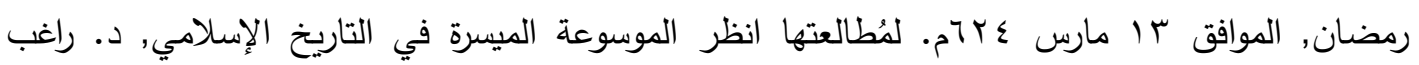

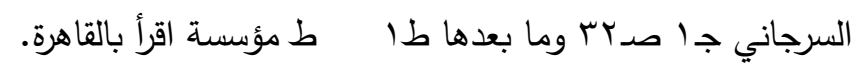

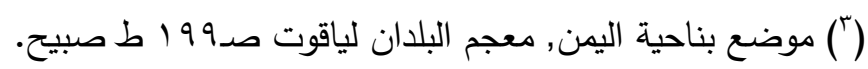

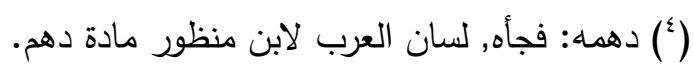

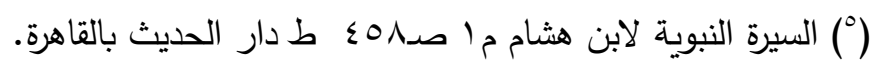




\section{حولية كلية الدعهوة الإسلامية بالقاهرة}

كهئه القيادة العسكرية من خلال قصة طالوت

ثانياً: وفى هذه الفترة قُبيل التحام المسلمين بالمشركين في معركة بدر أيضـاً كانت مشورة

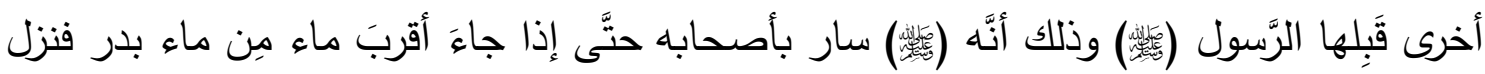

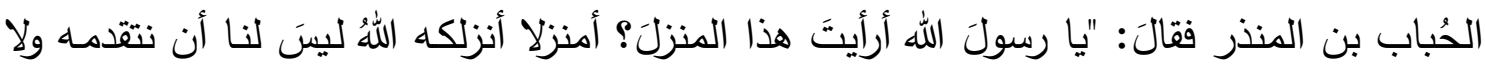

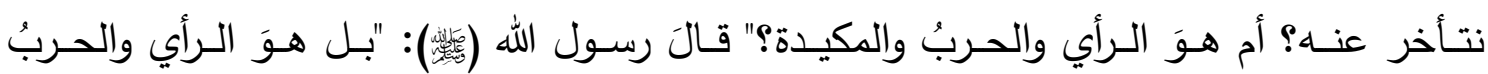

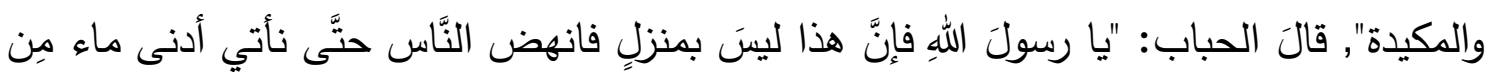

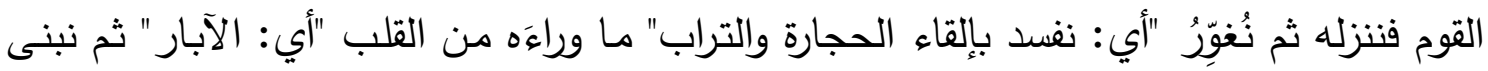

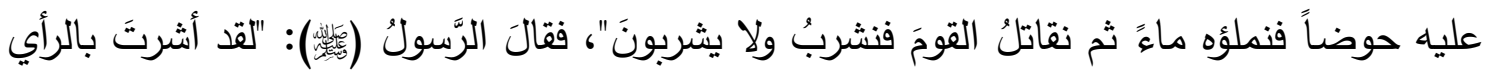

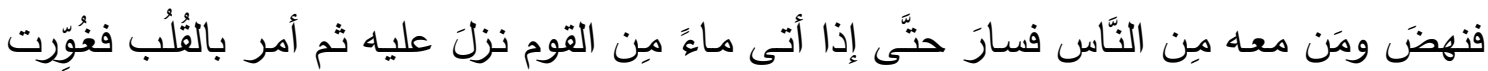

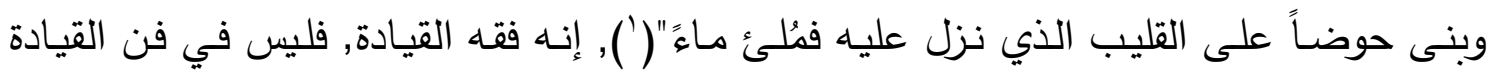

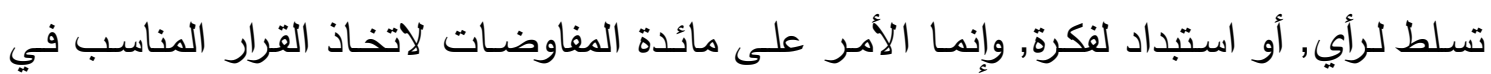
الوقت المناسب على الوجه المناسب, بما يُحقق الغاية والهدف.

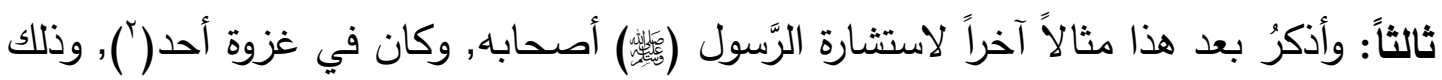

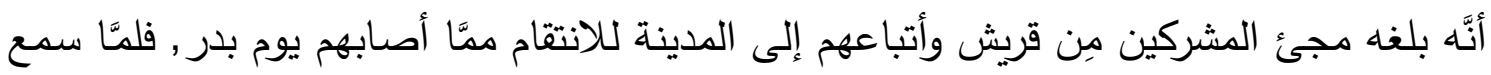

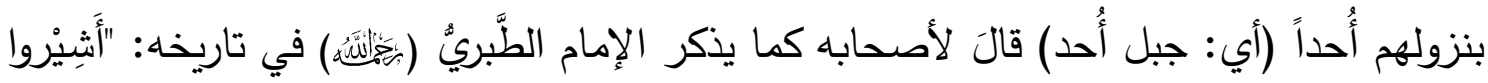

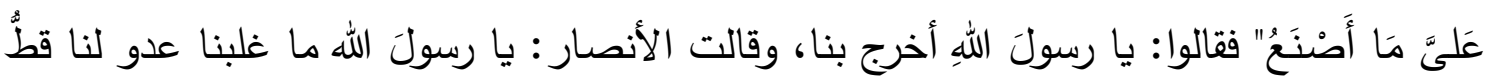
أتانا في ديارنا فكيفَ وأنت فينا (آ).

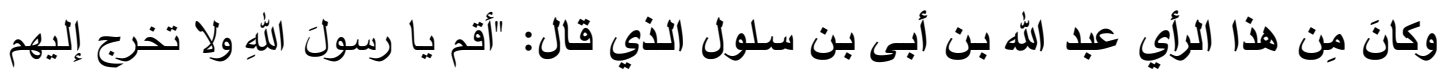

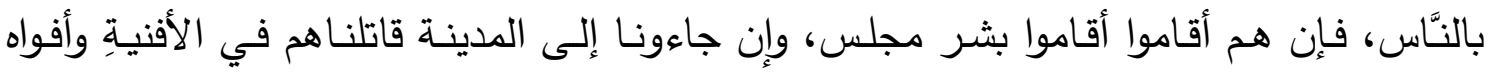

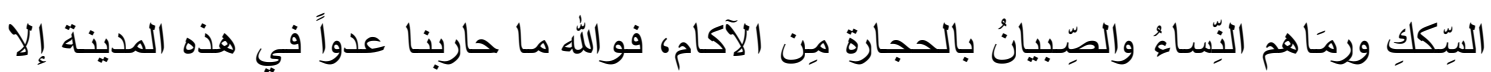

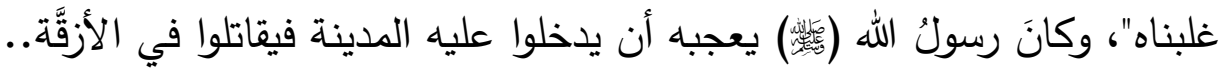

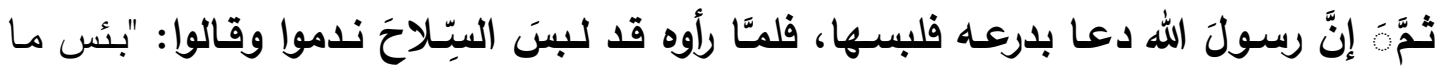

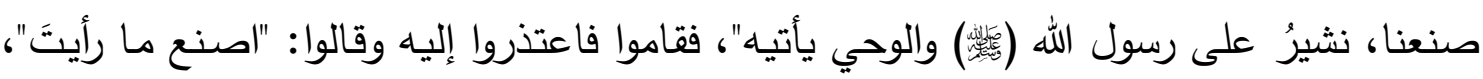

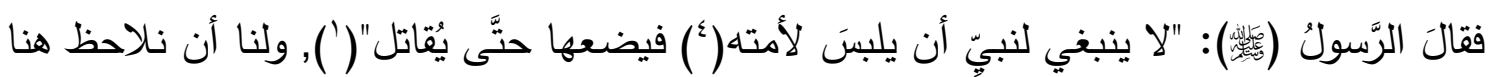

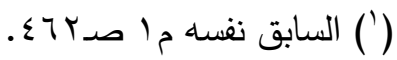

(') وكانت في العام الثالث من الهجرة, السابع من شهر شوال. ليُطالعتها انظر الموسوعة الميسرة في التاريخ

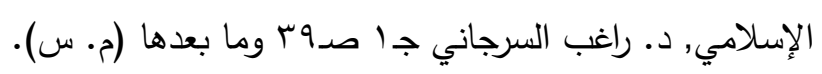

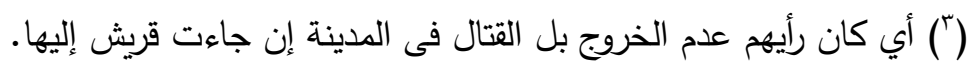
() التَلأمة: الدرع وقيل: السلاح ولأمة الحرب: أداته وقد يترك الهمز تخفيفاً. 


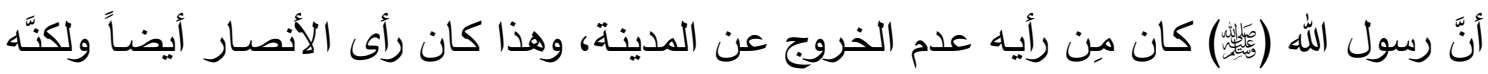

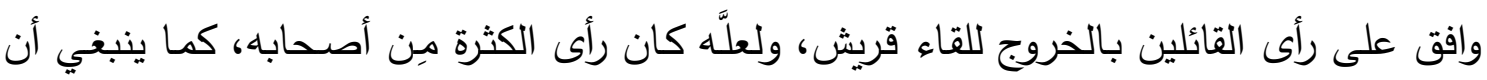

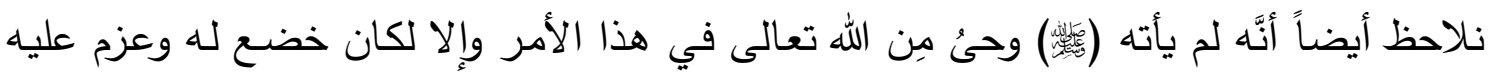
بطبيعة الحال سواء وافق رأى أصحابِه أو خالفهر. ومن هذا المنطلق يبقى مبدأ الثورى ملزما للقائد, وهو أحد أركان فقه القيادة, بل يُمثل قاعدة

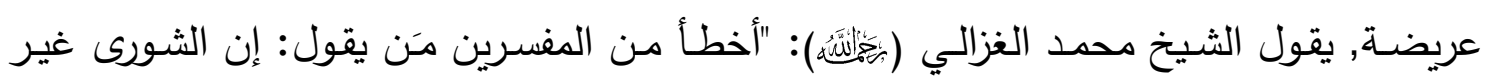

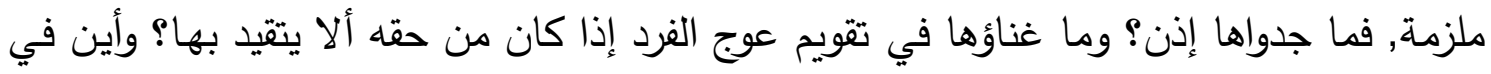

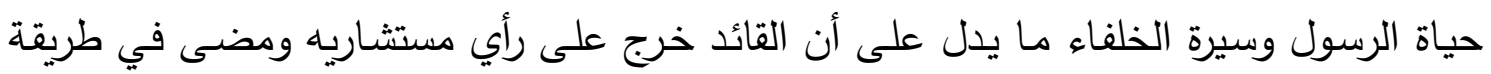
واحدة؟"(†), ويقول في موطن آخر : "أما القول بأن الإسلام أقر الثورى في الحسى الحكم, وأعفى الحاكم

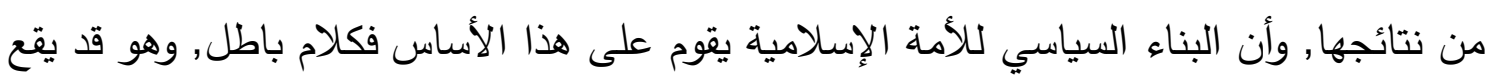

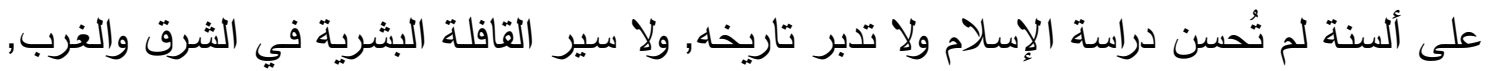
ولا وظيفة الأمة الإسلامية في العالم"("). وهكذا كان مبدأ الثَّورى دعامةً أساسيَّةً من دعائم فقه القيادة, يقول بشار بن برد (عِّيَ):

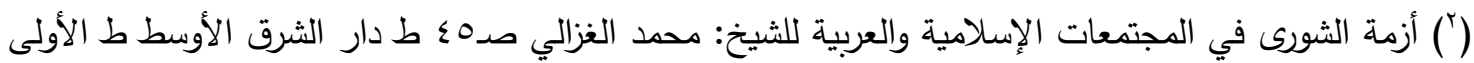

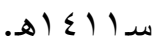
(") الإسلام والاستبداد السياسي للثيخ محمد الغزالي صده ط الثالثة ط دار الكتاب سدء . ؛ (هـ. 


\section{حولية كلية الدعهوة الإسلامية بالقاهرة}

كعِفقه القيادة العسكرية من خلال قصة طالوت

إذا بلغ الرأي المشورة فاستعن * برأي نصيح أو نصيحة حازم

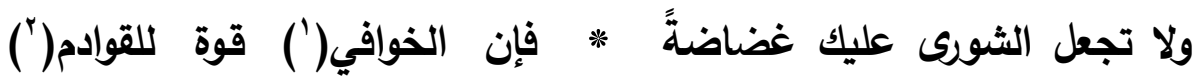

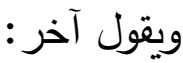

الرأي كالليل مسـود جوانبه * والليل لا ينجلي إلا بإصباح

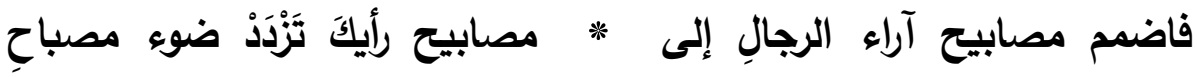

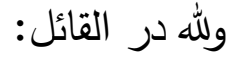

رأي الجماعة لا تثقى البلاد به * رغم الخلاف ورأي الفرد يُشقيها

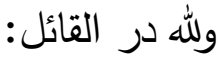

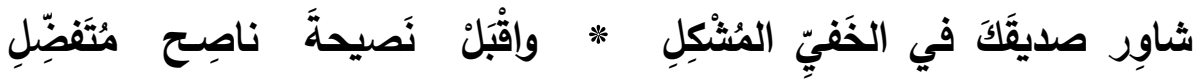

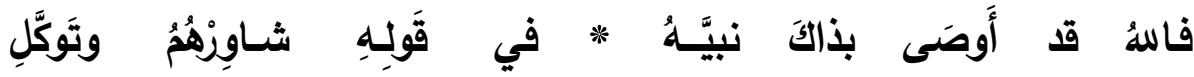

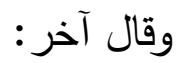

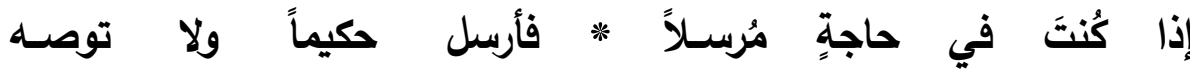

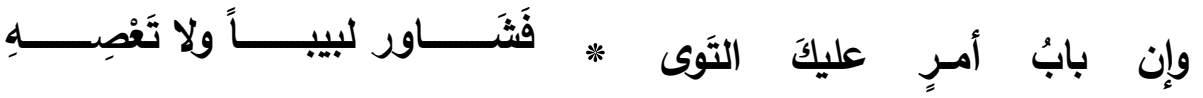

$$
\text { (') (') الخوافي: ما دون الريشات العشر من مقدم الجناح. }
$$$$
\text { (') قوادم الطير : مقاديم ريثه وهي عثر في كل جناح, الواحدة: قادمة. }
$$ 


\section{الإطلب الرابع

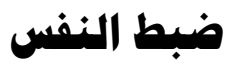

وهي دراسة كبيرة أسهب فيها علماء علم النفس والاجتماع لما يرتبط بها من عوامل فسيولوجية وسيكولوجية أو عضوية ونفسية, وهي تتطلب من القائد أن تكون لديـه القدرة على التَّكَكم في نفسـه بضبطها مهما كان الموقف, وهي أكثر مـا تكون ارتباطسا بالجانب الخُلُقي, حيث ضبط النفس وترك الغضب وتجنب المؤثرات, لما يترتب عليها من أضـرار وخيمـة, خاصـة عند صـانع القرار , الذي يُوجب عليه موقعه الحسَّاس ضبط النفس والتؤدة والتروي, واتخاذ القرار المناسب في الوقت المناسب, بعد تأمل وتدبر , بالفحص والدرس.

وضبط النفس هذا عامله الرئيس هو: العلم الشرعي, فإنـه مما لا شك فيه أن القائد لابد أن يكون ملما بـه, ففيـه تزكية للنفس وترويض لها على الفضـائل وتجنب النقائص, وإن من نتيجة ذلك أن يكون القائد على بصيرة من أمره, وهو مما يتحبب بـه إلى أنصـاره أو أفراد مؤسسته, وبذلك يتجنب الانزلاق إلى المهالك, ولذلك فسّر بعض العلماء قوله سبحانه في شخصية القائد

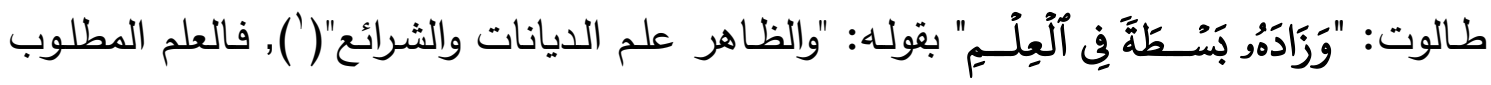

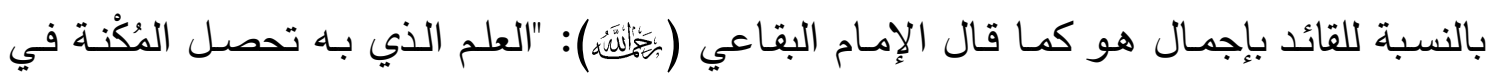
التدبير والنفاذ في كل أمر"( ) , ولهذا كان الجهاد نوعين: الأول: جهاد باليد والسنان، وهذا المشارك فيه كثير •

والثاني: الجهاد بالحجة والبيان، وهذا جهاد الخاصة من أتباع الرسل، وهو جهاد الأئمة، وهو أفضل الجهادين لعظم منفعته، وشدة مؤنته، وكثرة أعدائه، قال تعالى في سورة الفرقان وهي مكية:

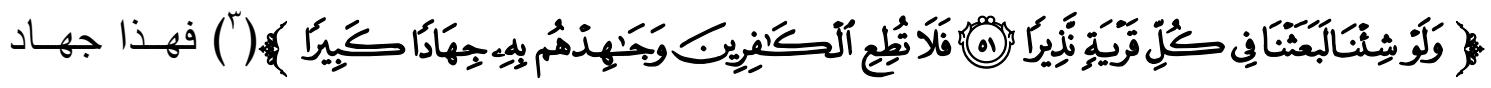
لهم بالقرآن وهو أكبر الجهادين"(").

$$
\begin{aligned}
& \text { (') البحر المحيط للإمام أبي حيان جr صدצجr (م. س). }
\end{aligned}
$$

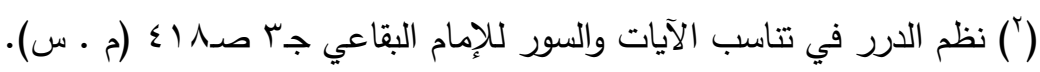

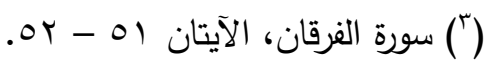

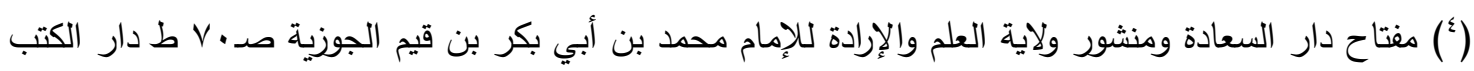

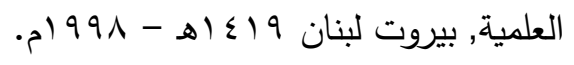




\section{حولية كلية الدعهوة الإسلامية بالقاهرة}

كهيقهة القيادة العسكرية من خلال قصة طالوت

وممـا لا شك فيـه أن التقوى تأتي في طليعة ثـرات العلم النافع، وهذا مستقى من وصف الله لطالوت بأنه أوتي بسطة في العلم، إذ ما نفْع العلم إن لم تظهر آثاره بالتقوى، ولذلك كان السلف

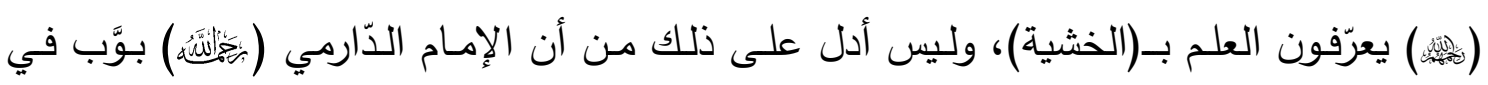
سننه "باب من قال: العلم الخشية وتقوى الله"(').

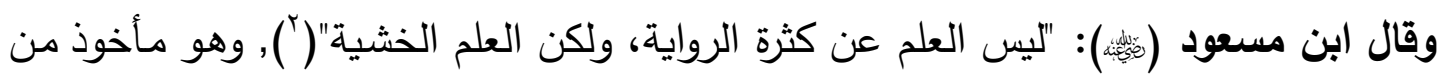

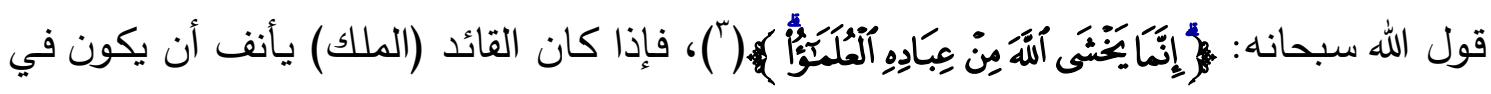
رعيته من هو أنفذ أمراً منه، فكذلك ينبغي له أن يأنف من أن يكون في رعّيته من هو أفضل ديناً

ولقد كان هذا جزءا من خطة القائد المُلهَم طالوت في المعالجة وتصحيح المسار , فإن من أهم الأهداف التي حرص عليها طسالوت: تقويم أخلاق اليهود بتزكيتها وإعادة ضسطها دينيَّا بعدما أطلقوا لها العنان، فهم القوم الذين ساءت أخلاقهم وفسدت فطرتهم، وكل هذا الصنيع حتى يكونوا على استعداد تام لمجابهة الأعداء في القتال, ولكن قبل ذلك كله يلزم في حق القائد: "ذا الإمرة والسلطان أن يبدأ بسياسة نفسه, ليحوز من الأخلاق أفضلها, ويأتي من الأفعال أجملها, فيسوس الرعية بعد رياضته, ويقومهم بعد استقامته, فإذا بدأ بسياسة نفسه كان على سياسة غيره أقدر ، و إذا أهمل مراعاة نفسه كان بإهمال غيره أجدر , فبعيد أن يحدث الصـلاح عمن ليس فيه صـلاح, لأن ضرورة نفسه أمسّ, وهو بتهذيبها أخص"((0).

ولا يصـلح لسياسـة غيره من لا يصلـح لسياسـة نفسـه, ولهذذا ذم الله تعـالى من ترشـح لسياسـة

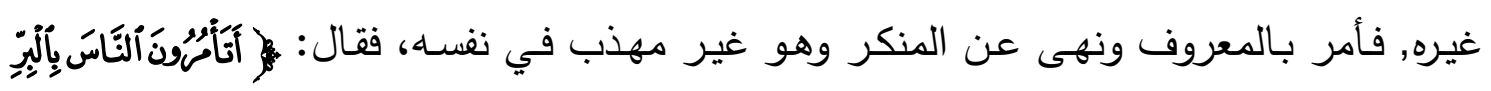

(') سنن الدارمي للإمام عبد الله بن عبد الرحمن جا صد99 تحقيق: فواز ولي, خالد السبع طا ط دار الكتاب

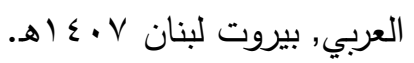

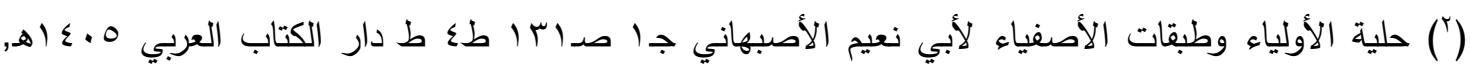

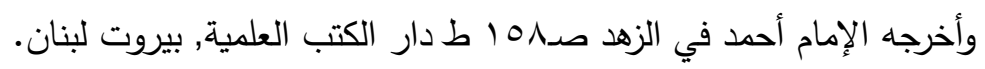

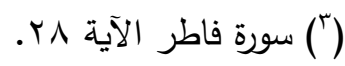

(") تسهيل النظر وتعجيل الظفر في أخلاق الملك وسياسة المتلك لأبي الحسن علي بن محمد بن حبيب الماوردي

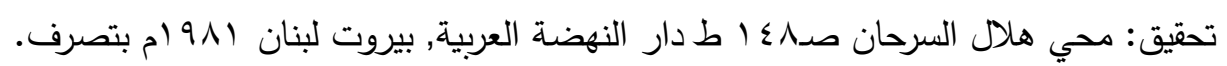

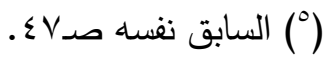


كعبقفه القيادة العسكرية من خلال قصة طالوت

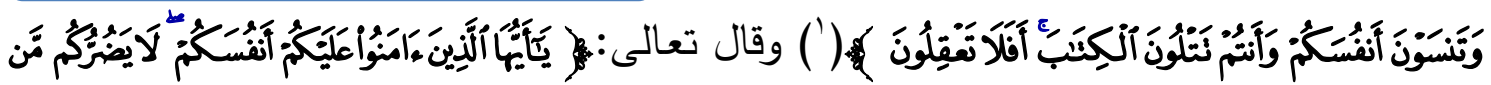

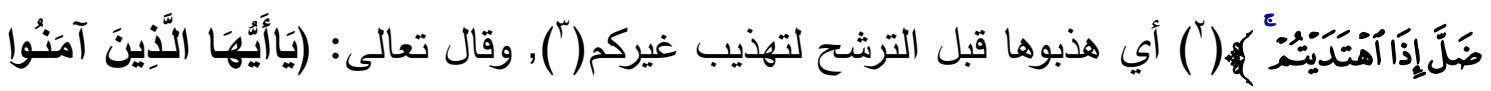

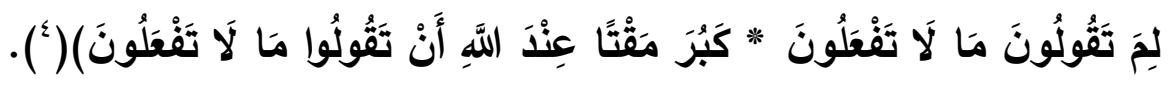

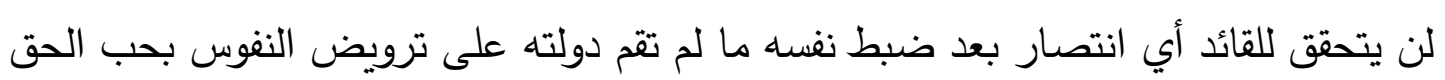

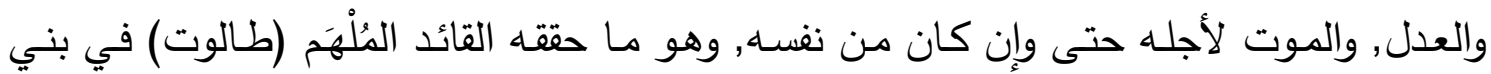

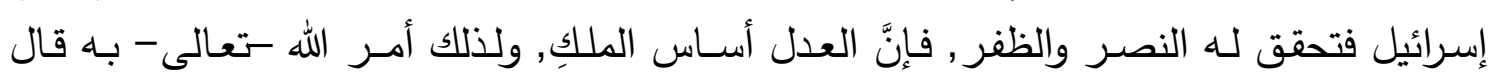
إِ

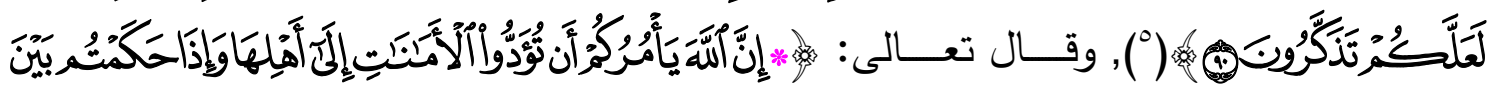

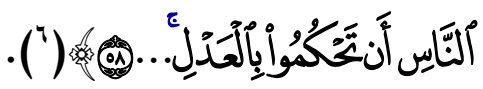

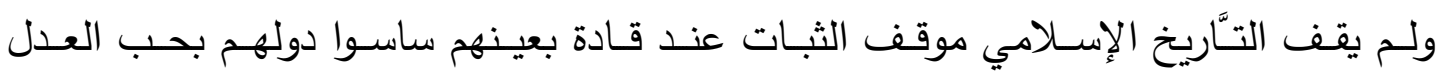

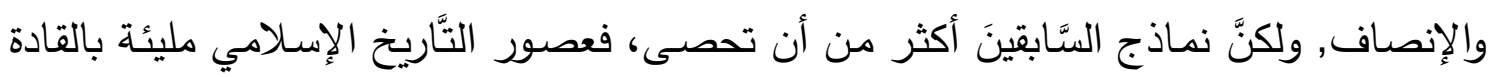

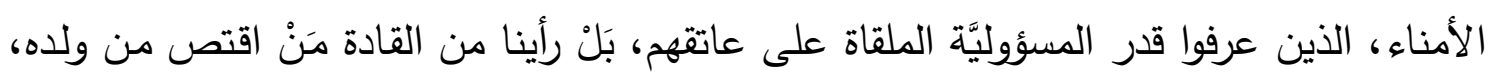

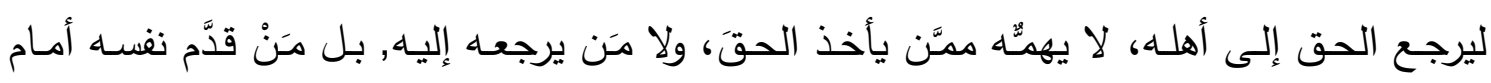

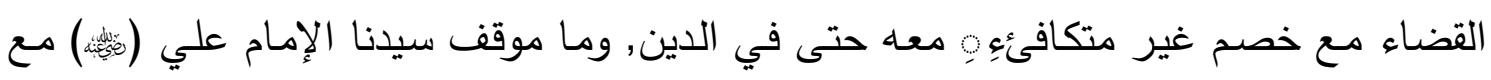
اليهودي منا ببعيد( ال).

ولقد جلسَ المأمونُ يوماً للمظالم، فكان آخر مَن تقدَّم إليه وقد هَّ بالقيام امرأة عليها هيئة

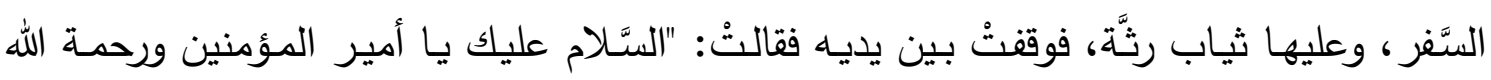

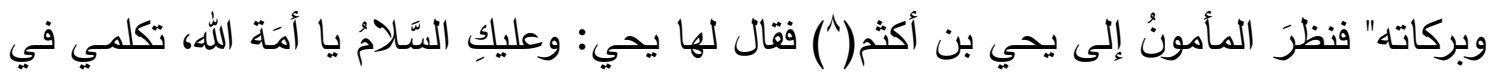
حاجتاك، فقالت:

$$
\begin{aligned}
& \text { (') (') سورة البقرة الآية ؟ ؟. }
\end{aligned}
$$

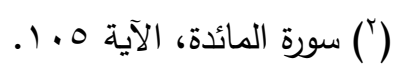

$$
\begin{aligned}
& \text { (") الذريعة إلى مكارم الثريعة للراغب الأصفهاني صدءم (م. س). }
\end{aligned}
$$

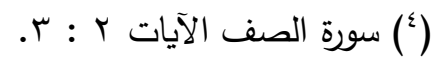

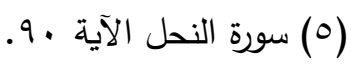

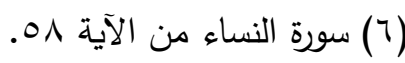

$$
\begin{aligned}
& \text { (') في قضية الدرع وهي مشهورة في كتب التأريخ والسير . }
\end{aligned}
$$

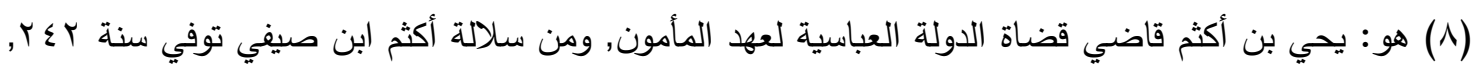

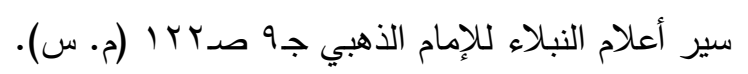




\section{حولية كلية الدعوة الإسلاهية بالقاهرة}

كهِفقه القيادة العسكرية من خلال قصة طالوت

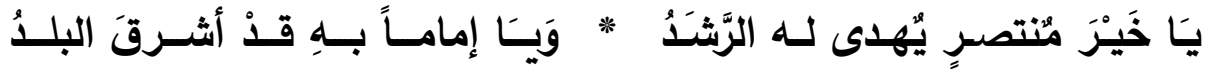

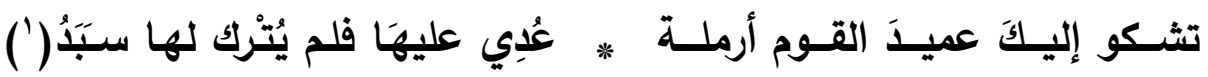

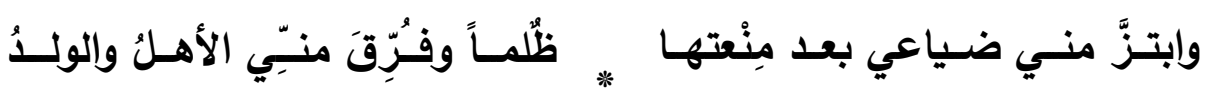

فأطرقَ المأمونُ حيناً ثُم رفحَ رأسه إليها وهو يقول:

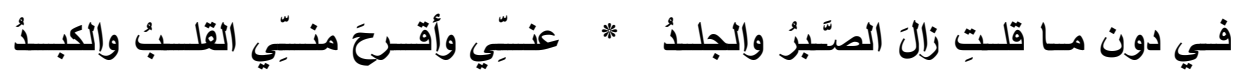

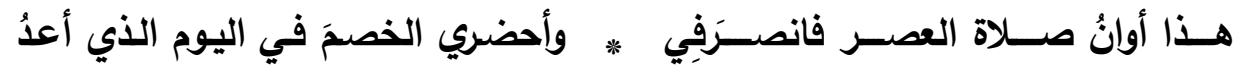

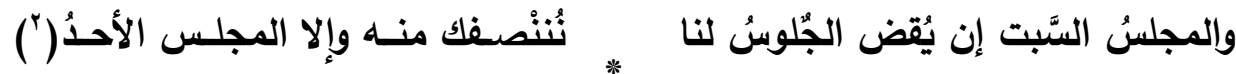

فلمَّا كانَ يوم الأحد جلس فكان أوَّل من تقدَّم إليه تلك المرأة فقالت: "الستّلام عليك يا أمير

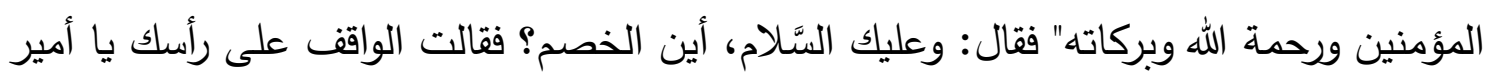

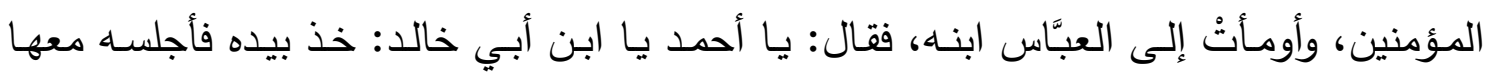

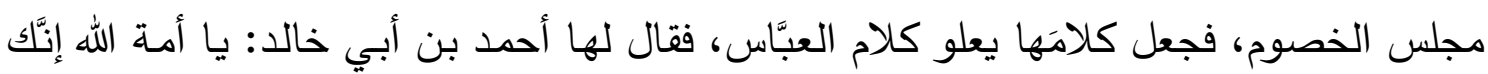

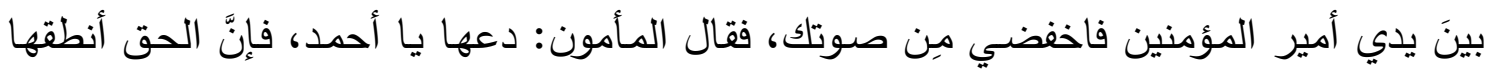

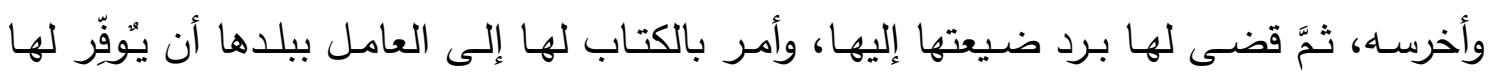
ضيعتها، ويُسن معونتها، وأمر لها بنفقة لَّآ). من هنا ينبغي أن تكون الانطلاقة التي يستطيع القائد أن يقف من خلالها على قدم وساق

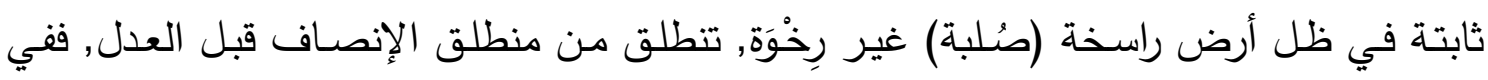

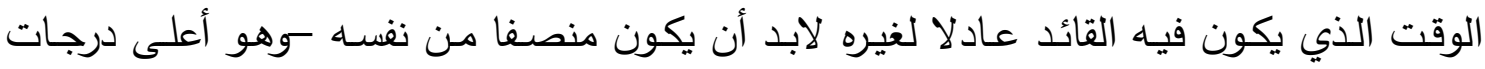

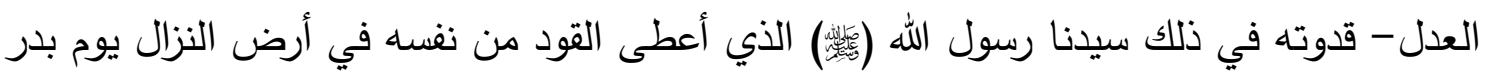
مع الصحابي الجليل سواد بن غزية (مثئة) فليتدبر وليتأمل.

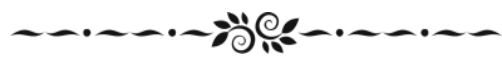

(') أصل السبد: القليل من الثعر , ويقال ما له سبد ولا لبد أي لا قليل ولا كثير.

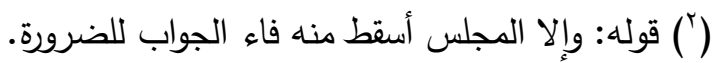
(") جواهر الأدب للسيد أحمد الهاشهي جـا صد ـ اء ط مؤسسة المعارف بيروت لبنان. 


\section{حولية كلية الدعوة الإسلاهية بالقاهرة}

كهِفقه القيادة العسكرية من خلال قصة طالوت

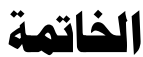

لعله بعد هذه التطوافة العلمية - التي أسأل لها التوفيق والسداد- حول فقه القيادة العسكرية

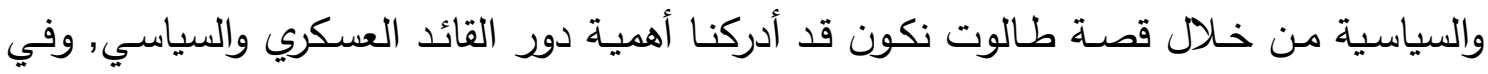
الوقت ذاته خطورة وحساسية موقعه من الأمة, لقد كان البحث فاصلا بين زمنين: الأول: عاشه بنو إسرائيل ذلا وانكسارا, وبكاءَ على الأطلال, لأنهم ضلوا بعدما هدوا, فذاقوا وبال أمرهم, وهذه سنة الله في كونه, وآية الله في خلقه.

الثاني: عاشه بنو إسرائل عزًاً وكرامة, باصطفاء الله لهم القائد طالوت بعد سؤالهم وطلبهح من

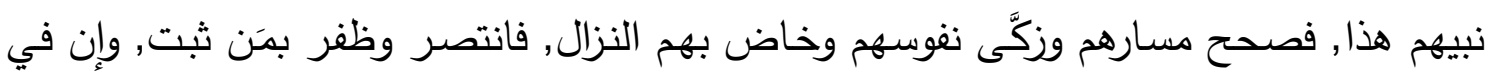

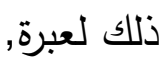

\section{أهم النتائج والتوصيات}

\section{أولاً: النتائُج}

• إن القصص القرآني هو أكبر مُعبِّر حقيقي عن تاريخ السابقين اسما ورسما, ودروسا وعبرا, دون محاباة أو مجاملة, بل الوقوف على أدق وأعمق التفاصيل.

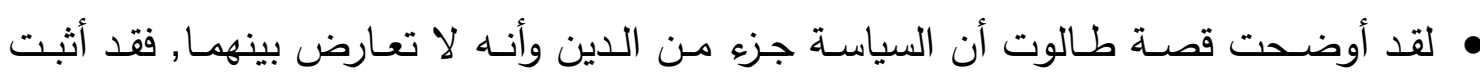

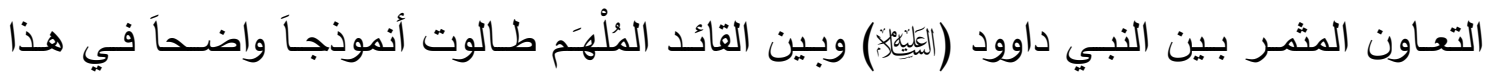

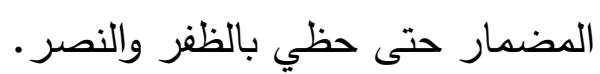
• لقد بلغ بنو إسرائيل قمة الانحطاط الأخلاقي والحضـاري قبل مجيء القائد المُلْهَمَ (طالوت), وتمزَّقوا شر ممزَّق, وتكالبت عليهم الأمم المجاورة, وتوالت عليهم الهزائم العسكرية, ولم يكن لهم

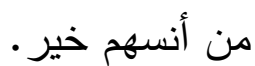
• لقد كان عهد القائد طالوت هو البداية الحقيقية لإعادة النفس إلى المسار الصحيح بعدما سوَّل لها شيطانها النزول إلى الهاوية في حالة من الجمود والتدني الأخلاقي. • لقد كان عهد طالوت هو البداية الحقيقة لحرب العزة والكرامة التي أعاد بها لبها لبني إسرائيل

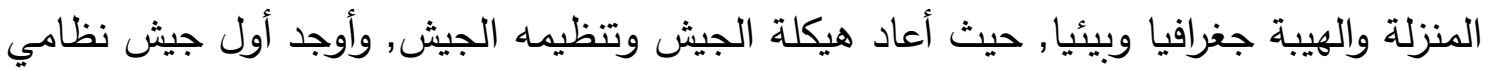
لبني إسرائيل من بعد عهد سيدنا موسى (الئلئز). 
كعنقه القيادة العسكرية من خلال قصة طالوت

• لقد أثبتت قصة طالوت أن النجاح الحقيقي للقيادة يتمثل في وجود قيادة: عاقلة واعية مدركة حاسـة ملمـة فقيهـة وطموحسة تستطيع أن تمتلك زمـام الأمسور وأن تُحسن المبـادرة واتخـاذ القرار المناسب في الوقت المناسب.

• إن اصطفاء الله تعالى لأحد في أيّ أمر من الأمور لا يقف عند مقاييس البشر , ولا يمكن أن

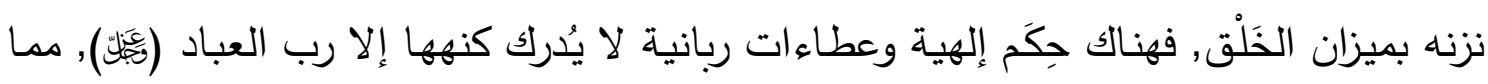
يستوجب التسليم والقبول. • ليست كل شخصية يمكن أن تكون قيادية ريادية, إنما هي الشخصية الكفه, المنضبطة نفسياً وأخلاقيا, المقدِرة لضوابط اختيارها, والدارسة لفنون الحرب وخدع القتال.

\section{ثانياً: التوصيات}

• لابـد من التعامل الراقي مـع القصـة القرآنية بغرض أخذ العظـات والعبر والوقوف على أدق تفاصيلها لأهميتها البالغة. هابـد من تتاول الدروس والعبر من خـلال قصـة طـالوت بالفحص والدرس للوقوف على فقهـ القيادة الناجحة, ومعالجة جوانب التقصير بعد التقييم والتقويخ. • ينبغي للقائد أن يمتلك المؤهلات القيادية, وأن يكون على دراية بخطورة الموقع الموجود فيه

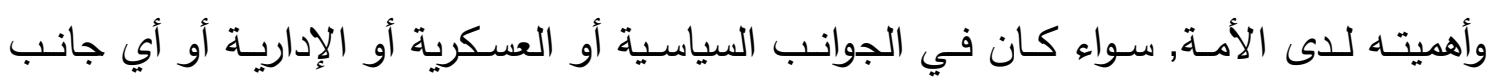
مؤسسي. • لابد للقائد أن تتوفر في شخصيته القدرة النفسية العالية, والاستعداد البدني المتكامل, وضبط النفس بأخلاقها الرفيعة في التعامل مع الأفراد أيَّاً كان الجانب المؤسسي. ه لابد من الإعداد التربوي للأفراد قبل التكليف بأي مهام حتى يُسهم هذا في تحقيق الأهداف والغايات. • علينا أن نستقي مُثُلنا القيادية ونستلهم فقه القيادة الناجحة من القرآن الكريم وقادتنا العظام, وهم شموس ساطعة في تاريخ الأمسة الحافل بالنضـال, بعيداً عن التأسي بما قذفته لنا الحضـارة الغربية من وهم النظريات القيادية المُزْرية. 


\section{المادر والمراجع}

1- القرآن الكريم - جلَّ مَن أنزله.

r- الحدود الأنيقة والتعريفات الدقيقة للعلامة زين الدين أبو يحيى زكريا بن محمد بن أحمد

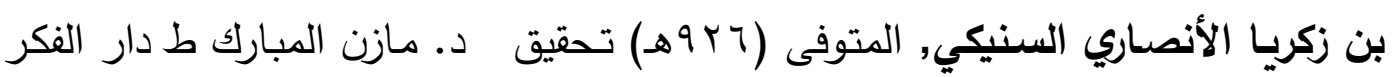

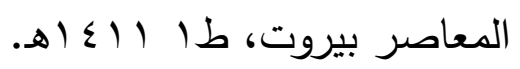

r- الراغب الأصفهاني، الذريعة إلى مكارم الثريعة للراغب الأصفهاني، طا ط دار السـلام بالقاهرة,

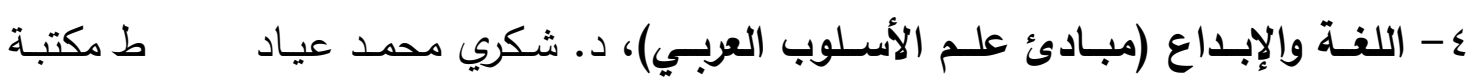

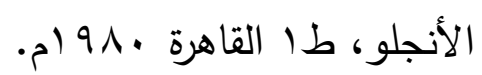

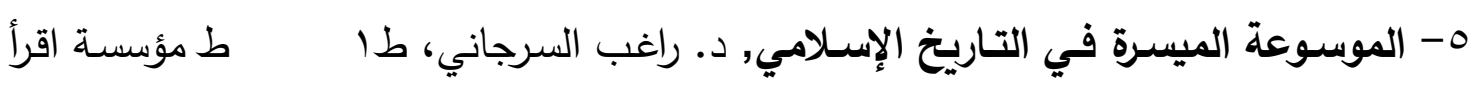

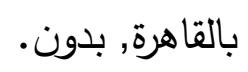

צ- تسهيل النظر وتعجيل الظفر في أخلاق الملك وسياسة المُّك، لأبي الحسن علي بن محمد

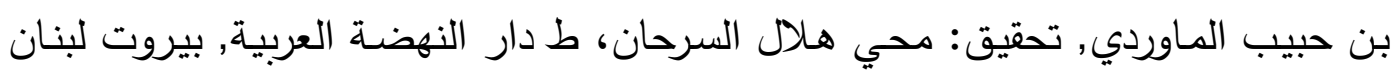
. 1911

V- جامع الأصول في أحاديث الرسول، للإمام مجد الدين أبو السعادات المبارك بن محمد بن

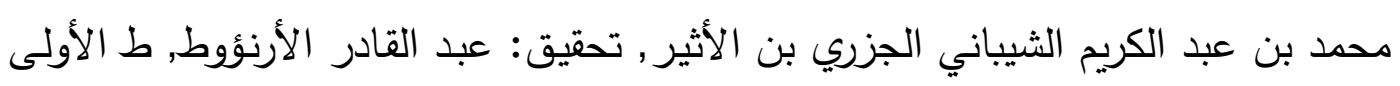
ط مكتبة الحلواني, بدون.

1- روح المعاني في تففير القرآن العظيم والسبع المثاني، للإمام الألوسي، ط دار إحياء التراث العربي, بيروت لبنان, بدون.

9- زاد المسير في علم التفسير، للإمام أبي الفرج عبدالرحمن بن الجوزي، ط دار الكتب

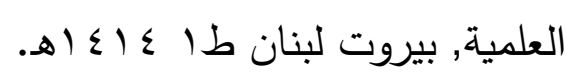

• 1 - أبجديات البحث في العلوم الثرعية، د. فريد الأنصاري منشورات الفرقان, الدار البيضاء,

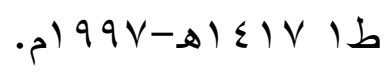

1 - الأحكـام السـلطانية والولايسات الدينيـة، للإمـام أبي الحسن علي بن محمد بن حبيب

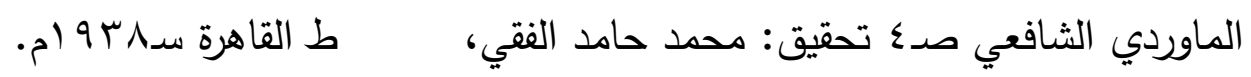




\section{حولية كلية الدعهوة الإسلاهية بالقاهرة}

كهِفقه القيادة العسكرية من خلال قصة طالوت

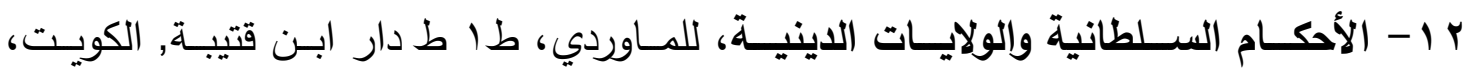

$$
\text { . }) 9 \wedge 9-8) \leq \cdot 9
$$

با - أسد الغابة في معرفة الصحابة، لابن الأثير تحقيق: محمد ابراهيم البنا, أحمد عاشور , محمود فايد, ط دار الثعب القاهرة سد • 9 ام.

ع ا - إعداد الجندي المسـلم أهدافـه وأسسـه، لعبدالله بـن فريح العقلا، طا ط مكتبـة الرشـد،

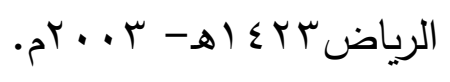

ه - الأنماط القيادية وعلاقتها بالأداء الوظيفي، د. طلال عبد الملك الثريف رسالة ماجستير

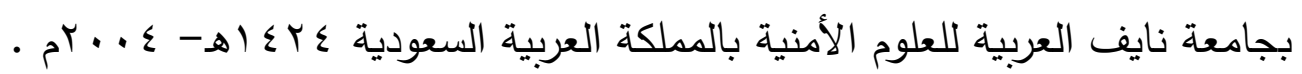
צ ا - البحر المحيط، للإمام أبي حيان الأندلسي، طا ط دار الكتب العلمية بيروت سا ع اهـ. 999

V ا البحر المحيط، للإمـام أبي حيان تحقيق: أحمد عادل, على معوض, ط دار الكتب

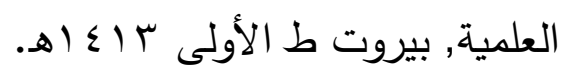

1 ا - البحر المحيط، للإمام محمد بن يوسف أبو حيان الأندلسي، تحقيق: أحمد عادل -علي معوض، ط دار الكتب العلمية، طا ط (بيروت لبنان س إك (هـ).

9 ا - البداية والنهاية، لابن كثير، طا ط دار الريان, القاهرة, 1 • ع أه.

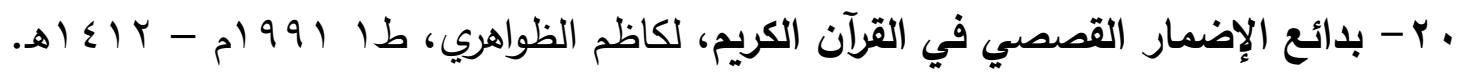
ا ب - البرهان في علوم القرآن، للإمام الزركثي تحقيق: محمد أبو الفضل ابراهيم ط دار إحياء الكتب العربية، طا بيروت $90 \mathrm{~V}$ ام.

r r - بنـو إسـرائيل في القـرآن والسـنة، للشيخ محمد سيد طنطاوي، طب ط دار الشـروق

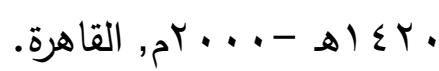

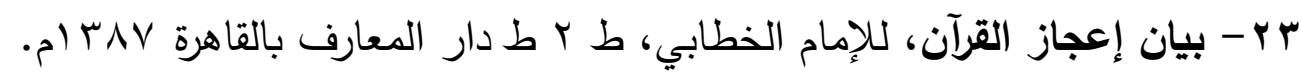
צ ץ - تاج العروس للزبيدي, محمد بن محمد بن عبد الرزاق الحسيني الملقب بمرتضى, تحقيق: مجموعة من المحققين, طبعة دار الهداية, بدون.

ه r - التبر المسبوك في نصيحة الملوك، للإمام محمد أبي حامد الغزالي تحقيق: أحمد شمس

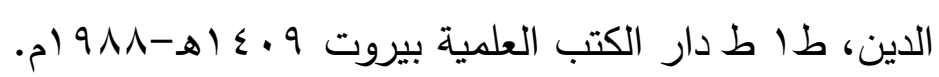




\section{هولية كلية الدعوة الإسلاهية بالقاهرة}

كعه فقه القيادة العسكرية من خلال قصة طالوت

צr - التحرير والتنوير، للإمام الطاهر ابن عاشور التونسي، ط دار سحنون, تونس V9 ام.

V V - التحرير والتنوير، للإمام الطاهر بن عاشور، ط دار سحنون, تونس, بدون ت.

^ ץ - الترغيب والترهيب، للإمام الحافظ المنذري ط دار الحديث القاهرة, بدون.

q ץ - التعريفـات, علي بـن محمد بـن علي الزين الشـريف الجرجـاني ط دار الكتب العلميـة,

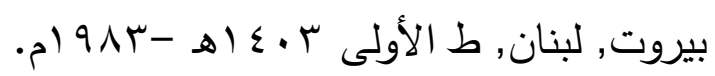

• ب- تفسير القرآن العظيم، للإمام ابن كثير ، ط مكتبة أسامة بالقاهرة.

اس - تفسير القرآن، للإمام أبي المظفر منصور بن محمد بن عبد الجبار السمعاني تحقيق:

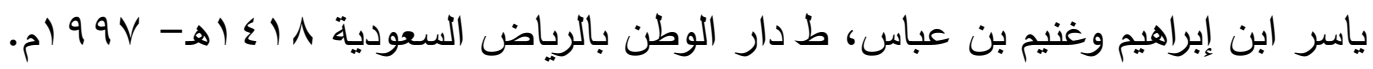
ץ r- التفسير الكبير ومفاتيح الغيب، للإمام الفخر الرازي، ط دار الفكر طا بيروت، الخازن، علاء الدين علي بن محمد الثيحي, بدون.

بس- تفسير لباب التأويل في معاني التنزيل، للإمام الخازن تحقيق: محمد علي شاهين، طا ط دار الكتب العلمية بيروت 0 إ أهـ

ع ب - التناسب البياني في القرآن، لأحمد أبو زيد، ط مطبوعات جامعة محمد الخامس بالرباط . $199 r$

ه ب- جامع البيان في تأويـل آي القرآن، للإمـام الطبري طا ط مؤسسة الرسالة, دمشق, بدون

צ - الجـامع لأحكـام القـرآن، للإمـام القرطبي تحقيق: سـير البخـاري، ط دار عـالم الكتب، الرياض، ومعالم التنزيل في تفسير القرآن للإمام البغوي جـا صده ج طء ط دار طيبة, السعودية, بدون.

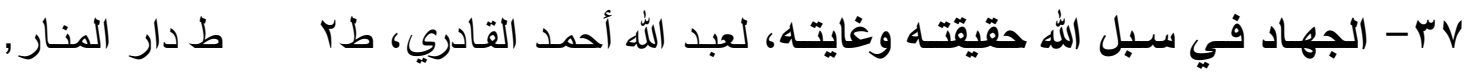

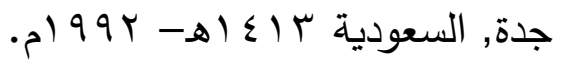

^ - جواهر الأدب، للسيد أحمد الهاشمي ط مؤسسة المعارف بيروت لبنان, بدون. q ب- حسن السلوك الحافظ دولة الملوك لابن الموصلي تحقيق: فؤاد عبد المنعم، طا ط دار الوطن 7 إـ أهـ 


\section{حولية كلية الدعهوة الإسلاهية بالقاهرة}

\section{كعه فقه القيادة العسكرية من خلال قصة طالوت}

• ع - حليـة الأوليـاء وطبقـات الأصـفياء، لأبي نعيم الأصبهاني، طع ط دار الكتاب العربي ه ـ أهـ, الزهد للإمام أحمد بن حنبل ط دار الكتب العلمية, بيروت لبنان.

اء - الخطاب القرآني, سليمان عشراني, ديوان المطبوعات الجامعية الجزائر 919 ام.

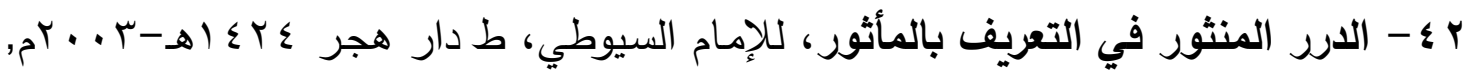

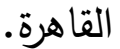

بع - دلالـة السـياق, د. ردة الله الطلحي, معهد إحياء التراث الإسـلامي ط ب ط مكة المكرمـة . ه $\leqslant$ ( )

ع ـ - دلائـل الإعجـاز, أبو بكر عبد القادر الجرجاني تحقيق: محمود محمد شـاكر، ط مكتبة الخانجي بالقاهرة ع19 (م.

ه ؛ - دلائل الإعجاز، للإمام الجرجاني تحقيق: محمود شاكر ، ط الخانجي بالقاهرة ع19 ام. צ ـ - روح العـاني في تفسير القرآن العظيم والسـبع المثـاني، للإمـام شهاب الدين محمود الآلوسي، ط دار التراث, القاهرة.

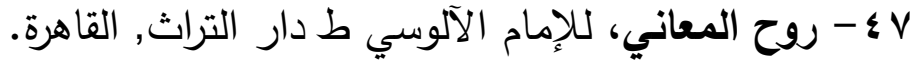
^ ـ - الروح، للإمام ابن القيم ط دار الكتب العلمية بيروت هوب أهـ-9 أم. وء - زاد المسير في علم التفسير، للإمـام أبي الفرج عبد الرحمن بن علي بن محمد بن الجوزي، طس ط المكتب الإسلامي, بيروت لبنان ع . ـ إهـ

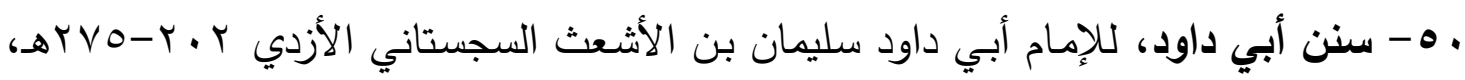
ط دار إحياء التراث العربي بيروت بلبنان. اه - سنن الدارمي، للإمام عبد الله بن عبد الرحمن تحقيق: فواز ولي, خالد السبع، طا ط دار الكتاب العربي, بيروت لبنان V • ع اهـ. ro - السـنن الكبرى، للإمـام أبي عبد الرحمن أحمد بن شعيب بن علي الخرسـي النسـئي,

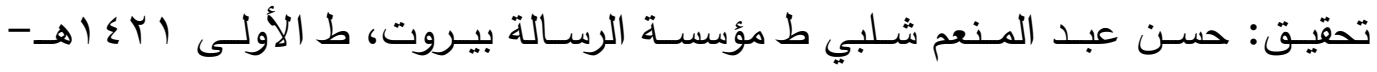

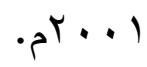

به - السياسة الشرعية، للشيخ عبد الوهاب خلاف ط دار الشعب, بدون. 


\section{حولية كلية الدعهوة الإسلاهية بالقاهرة}

كهيقهة القيادة العسكرية من خلال قصة طالوت

ع هـ الســيرة النبوبـة، لأبـي محمـد عبـد الملك بـن هشـام المعـافري، طـدار الحـديث بالقـاهرة

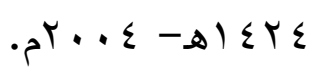

هـ - صحيح مسلم، بشرح النووي ط دار الحديث بالقاهرة، ط الرابعة سنة r بـ أهـ- + . . م. צه - الطبقات الكبرى، لابن سعد طدار صادر , بيروت لبنان, بدون.

V V الطريق إلى القيادة وتتميـة الشخصية لكورتوا, ترجمـة: سـالم العيسي, طا ط دار عـلاء الدين, دمشق.

^ه - عبد الكريم زبدان ومنهجه في التأصيل الدعوي من خـلال كتابـه أصول الدعوة، "رسالة

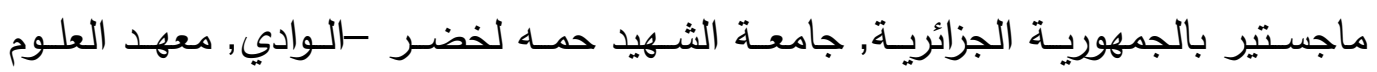
الإسـلامية, قسم أصـول الدين, تخصص: دعـوة وإعـلام, للباحثة برتيمـة حكيمـة, إشـراف

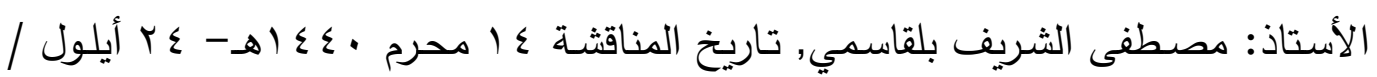

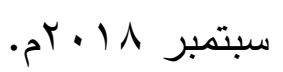

ه ه - علـم السياسـة، لمارسيل بريلو , ترجمـة: محمــ برجـاوي، ط منشورات عويـدات, بيـروت لبنان, بدون.

• ૧ - غرائسب القرآن ورغائب الفرقان، للإمـام نظام الدين الحسن النيسابوري تحقيق د. حمزة النشرتي وآخرين, ط بدون, وبدون ت.

ا - فتح الباري بشرح صحيح البخاري، للإمام الحافظ أحمد بن علي بن حجر العسقلاني، ط

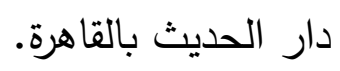

ץ צ - فتح القدير الجامع بين فني الرواية والدراية من علم التفسير، للإمام الشوكاني، طا ط دار الخير ، دمشق, بدون.

ب - فتح القدير، للإمام الشوكاني ط دار الخير ، ط الأولى دمشق r إع اهـ. ـ צ - فتح القدير، للإمام محمد بن علي الشوكاني، طدار الخير طا ب إ؛ اهـ. ه - فن القيادة في الاسدلام، لأحمد بصبوص، طا الأردن ط مكتبة المنار 9 ام.

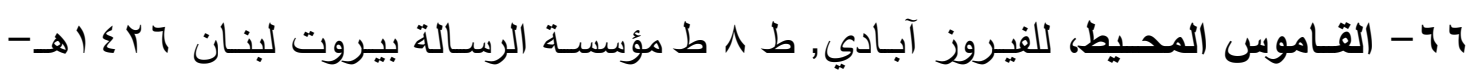
$\cdot$. 0

V V - القرآن الحكيم (تفسير المنار): محمد رشيد رضا، طץ ط مطبعة المنار بالقاهرة, بدون. 


\section{حولية كلية الدعهوة الإسلاهية بالقاهرة}

كهيقفه القيادة العسكرية من خلال قصة طالوت

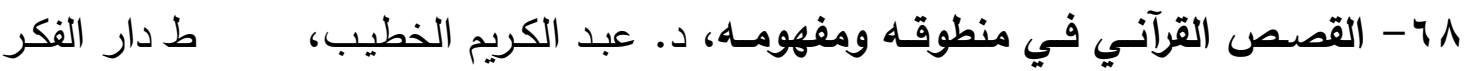
العربي, بيروت لبنان 970 ام.

9 - القصص القرآني في منطوقه ومفهومه، لعبد الكريم الخطيب، طب بيروت ط دارالمعرفة .5) $9 \vee 0-81 \% 90$

• V - القيادة: الأسباب الذاتية للتنمية القيادية، لجاسم بن محمد مهلهل الياسمين، طا ط دار الوفاء بالقاهرة سنة 991 (م. ا V- كثـاف اصطلاحات الفنـون, محمد علي التهانوي الحنفي, راجعه: أحمد حسن بسج، ط

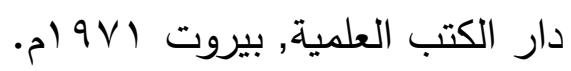

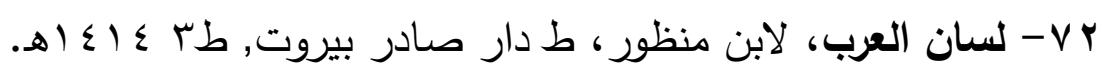
rV - المرشد السـيم في المنطق الحديث والقديم، د. عوض الله حجازي، طدار الطباعة المحمدية بالقاهرة, بدون.

ع V- مسـند الإمـام أحمـ بـن حنبل, شرح وفهرسـة: أحمد شـاكر ، طكتبة التراث الإسـلامي, بدون. ه V- مسند الإمام أحمد بن حنبل، ط دار الفكر العربي، بيروت المكتب الإسلامي. V V - معالم التفسير في تنزيل القرآن، للإمام البغوي, بدون. -VV معجم الرائد، لجبران مسعود، ط دار العلم للملايين, بدون ت.

^v - المعجم الوسيط, نخبة من ذوي الاختصاص بمجمع اللغة العربية، ط مكتبة الشروق

$$
\text { ط ط ז }
$$

q V - معجم مقــاييس اللفـة، للعلامـة أبي الحسن أحمد بـن فـارس بـن زكريـا القزويني الرازي

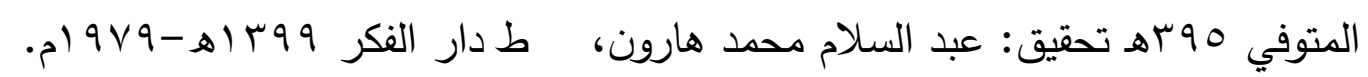
ـ - مفاتيح الغيب، للإمام الفخر الرازي، ط دار الفكر بيروت ؛ اءـ اهـ. ای- مفتـاح دار السـعادة ومنشـور ولايـة العــم والإرادة، للإمـام محمد بـن أبي بكر بن قيم

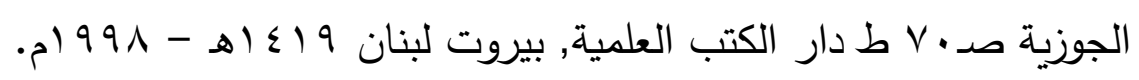

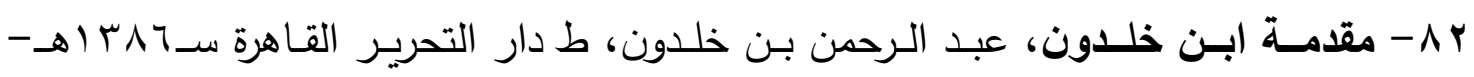
. 1977 


\section{حولية كلية الدعهوة الإسلامية بالقاهرة}

كعَفقه القيادة العسكرية من خلال قصة طالوت

ب - من أسرار التعبير القرآني (دراسة تحليلية لسورة الأحزاب)، د. محمد محمد أبو موسى ط مكتبة وهبة طن القاهرة 999 (م.

؛ ^- مناهج البحث العلمي في الإسلام, عبد الرّحمن بدوي ط وكالة المطبوعات, الكويت, ط.

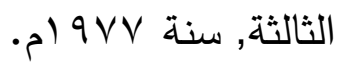

ه - منـاهج البحث العلمي وضـوابطه في الإسـلام، د. حلمي عبد المنعم صـابر ، ط مكتبـة

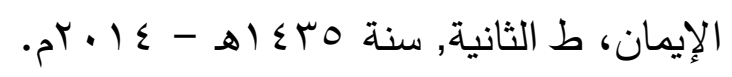

צ 1 - مناهج البحث العلمي، د. عبد اللطيف محمد العبد ط مكتبة النهضـة المصرية بالقاهرة، . م) $9 \vee 9-81 \% 9 \wedge$ b

N V مهارات البحث العلمي في الدراسات التربوية والاجتماعية، د. د. حافظ فرج أحمد ط عالم الكتب, بدون ت.

^^ - نظم الدرر في تناسب الآيـات والسـور، للإمـام برهان الدين البقاعي، ط دار الكتب

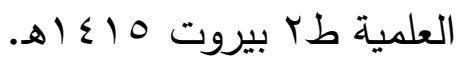

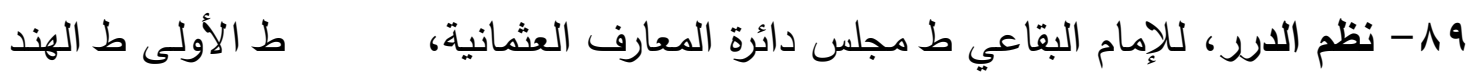
حيدر آباد اوه أهـ

• 9- النظم القرآنـي في آيـات الجهاد، لناصر بن عبد الرحمن بن ناصر الخنين، ط مكتبة التوبة طا الرياض 17 (1) (هـ- 999 (م.

ا9 - اليهـود في تـاريخ الحضـارات الأولـى، لغوستاف لوبون ترجمـة: عـادل زعيتر ، تحقيق: محمود النجيري، طا ط مكتبة النافذة بالقاهرة 9 ـ. . بم.

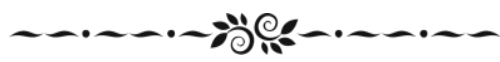




\section{كهُفقه القيادة العسكرية من خلال قصة طالوت}

\section{فهرس المرضوعات}

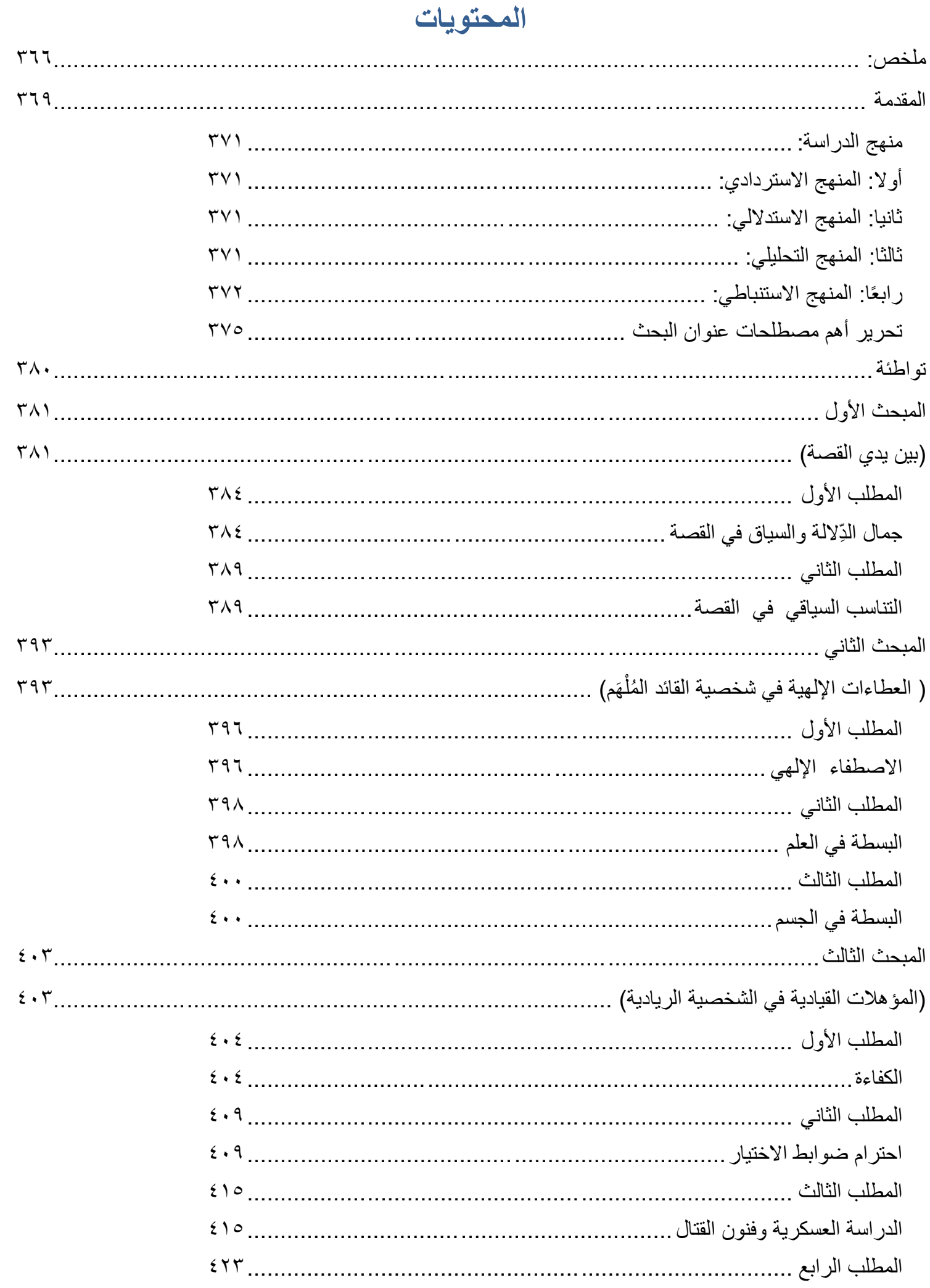


حولية كلية الدعهوة الإسلاهية بالقاهرة

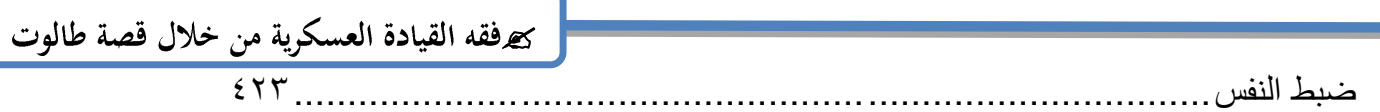

$\varepsilon Y V$. الخاتمة .

EYV أهم النتائج و التوصيات .

$\varepsilon r V$. أو لاً: النتائج .آ.

$\varepsilon r \wedge$. ثنانياً: التوصيات

$\varepsilon r q$

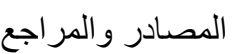

纟ry. فهرس الموضو عات .
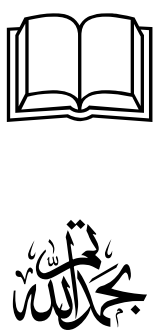